\title{
INFLUÊNCIA DO ZINCO E DO FERRO SOBRE A PRODUÇÃO DE PROTEÍNA FÚNGICA EM AMIDO DE MANDIOCA (Manihot esculenta Crantz)
}

\author{
GILDO ALMEIDA DA SILVA \\ Pesquisador da EMBRAPA - CNPMF
}

Orientador: Prof. Dr. Rodolpho de Camargo

Dissertação apresentada à Escola Superior de Agricultura "Luiz de Queiroz", da Universidade de São Paulo, para obłenção do tífulo de Mestre em Microbiologia Agrícola.

\author{
PIRACICA B A \\ Estado de São Paulo - Brasil \\ Maio, 1978
}


ii.

A meus pais e irmãos A Angela e Adriana

$D E D I C O$ 
Sinceros agradecimentos deverão ser dirigidos:

Ao Professor Dr. Rodolpho de Camargo, pela segura orientação e estímulo na execução deste trabalho e contríbuição para a minha formação de pesquisador;

A Empresa Brasileira de Pesquisa Agropecuária (EMBRAPA), pelo apoio finan ceiro concedido:

A Escol Superior de Agricultura "Luiz de Queiroz", de modo particular ao Departamento de Tecnologia Rural, pelas facilidades oferecidas para exe cução do presente trabalho;

A Chefia e colegas do Centro Nacional de Pesquisas de Mandioca Fruticul tura da Empresa Brasileira de Pesquisa Agropecuária (EMBRAPA/CNPMF);

Ao Departamento de Tecnologia Rural da ESALQ, nas pessoas dos Professores Dr. Otävio Valsechi, então Chefe do Departamento, e Homero Fonseca, pe la autorização da determinação de aflatoxina em materiais inerentes a este trabalho:

Ao Centro de Energia Nuclear na Agricultura, nas pessoas dos Professores Dr. Otto Jesu Crocomo, Henrique Bergamin Filho e Francisco José Krug,pe la aucorização das anäiises de zinco, ferro, aminoácidos e nitrogênio cotal: 
Aos Professores Dr. Roland Vencovsky e Humberto de Campos e ao colega da MMBRAPA/CNPMF Ranulfo Correia Caldas, pelas sugestões durante as anälises estatisticas dos dados:

Ao Colegas do curso de pós-graduação em Microbiologia Agrícola da ESALQ;

Aos Amigos Gustav e Daisy Westhoff, Dr. Jonas Vaz de Arruda e Maria de Lourdes Ortolani Arruda, Dr. Aloísio e Augusta Viana, Dr. Eurico e Olga Bueno de Souza, pelo apoio dispensado;

Aos Euncionários do Departamento de Tecnologia Rural da ESAlQ, em especial dos setores de Microbiologia de Alimentos e de Processamento e Bioquímica de Alimentos, bem como do Centro de Energia Nuclear na Agricultura, em particular das Secções de Química Analítica e de Bioquímica de Plantas, pela colaboração e execução das análises de aflatoxina, zin co, ferro, nitrogênio rotal e aminoácidos;

Aos Pucionários das Bibliotecas Central e do Departamento de Tecnologia Rural da ESALQ e da EMBRAPA/CNPMF;

A funcionária da EMBRAPA/CNPMF, Elane Borges Nascimento, pela execução dos serviços datilográficos.

A todos que, direta ou indiretamente, contribuiram para a reali zaço do presente trabalho. 


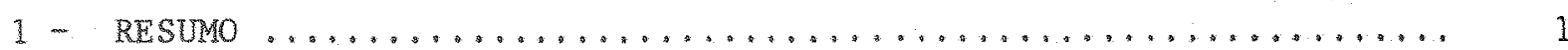

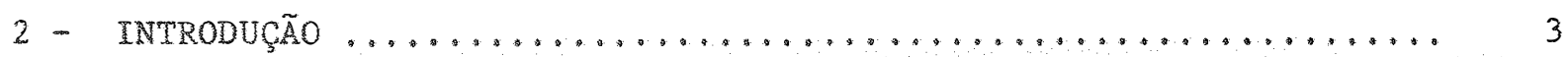

$3-\operatorname{REVISATO}$ DE LITERATURA $\ldots \ldots \ldots \ldots \ldots \ldots \ldots \ldots \ldots \ldots \ldots \ldots \ldots \ldots \ldots \ldots \ldots \ldots$

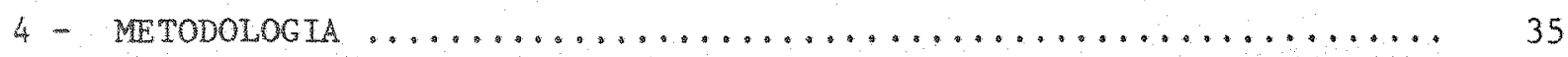

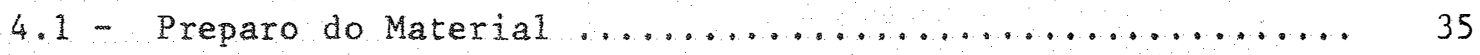

4.2 - Escolha do Microrganismo e Determinação do pll Otimo ..... 36

4.3 - Ensaio de Duas Fontes de Nitrogenio (Uréia e Nitrato de Amônio) para o Crescimento de Fusarium sp. Aspergil lus niger IZ-9 e Aspergillus wentii IZ-1625 em Meio de

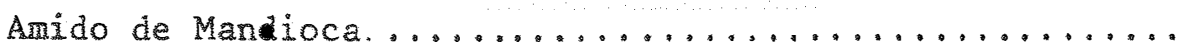

4.4 - Ensaio de Cinco Niveis de Zinco e Cinco de Ferro para o Crescimento de Aspergillus niger IZ-9 em Meio de

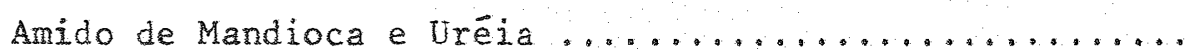

4.5 - Ensaio de Cinco Niveis de Ferro para o crescimento de Aspergillus niger IZ-9 em Meio de Amido de Mandioca, Uréia e Sulfato de Zinco na Concentração otima Encontra-

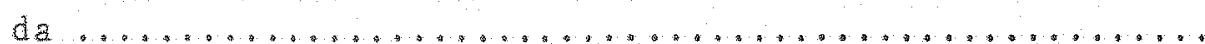

4.6 - Curva de Crescimento do Aspergillus niger IZ-9 em Meio de Amilo de Mandioca, Uréia, Sulfato de Zinco e Sulfa to Ferroso .............................. 40

4.7 - Determinação de Aflatoxina .................... 41

4.8 - Anälise Estatistica ....................... 41 
Pägina

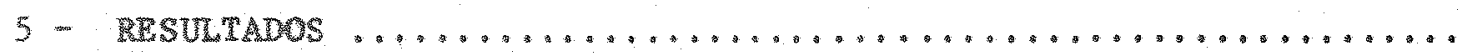

5.1 - Determinação do Teor de Micronutrientes no Arido de

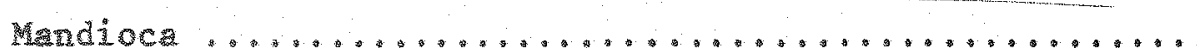

5.2 - Escolha do Microrganismo e Determinação do pH ttimo .....

5.3 - Ensaio de Duas Fontes de Nitrogênio (Urëia e Nitrato de Amônio) para o crescimento de Fusarium sp. Aspergil lus niger IZ-9 e Aspergillus wentii IZ-1625 em Meio de

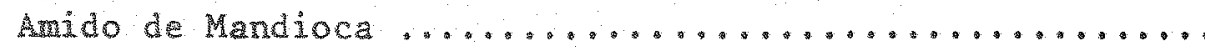

5.4 - Ensaio de Cinco Niveis de Zinco $(0,45-5,45-10,45-$ 15,45 a 20,45 ppm) e Cinco de Ferro $(0,51$ - 5,51 10,51 - 15,51 e 20,51 ppm) para o Crescimento de Aspergillus niger IZ-9 em Meio de Amido de Mandioca (3,0 gra mas de Carboidrato por Cento) e Uréia $(0,12$ gramas de

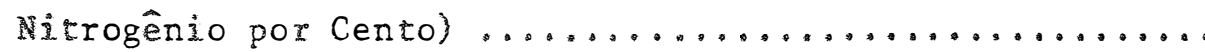

5.5 - Ensaio de Cinco Riveis de Ferr (15,51 - 20,51 - 25,51 $30,51$ e $35,51 \mathrm{ppm})$ para o Crescimento de Aspergillus niger. IZ-9 em Meio de Amido de Mandioca (3,0 gramas de Car boidrato por Cento), Urëia $(0,12$ gramas de Nitrogênio por Cento $)$ e zinco $(5,45$ pprn $) \ldots \ldots \ldots \ldots \ldots \ldots \ldots$

5.6 - Curva de Crescimento do Aspergillus niger IZ-9 m Meio de Amido de Mandioca $(3,0$ gramas de Carboidrato por Cen to) , Uréia (0,12 gramas de Nitrogênio por Cento), sul fato de Zirco $(5,45$ ppr de Zinco) e Sulfato Ferroso $(20,51$ ppm de Ferro) 
6.2 - Ensaio de Duas Fontes de Nitrogênio (Urëia e Nitrato de Amônio) para o Crescimento de Fusarium sp. Aspergillus niger IZ-9 e Aspergillus wentii IZ-1625 em Meio

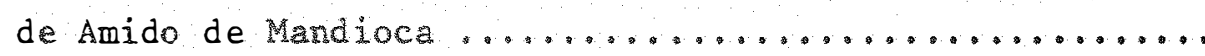

6.3 - Ensaios de Cinco Niveis de Zinco $(0,45-5,45=10,45$ 15,45 e 20,45 ppm) com Cinco de Ferro $(0,51$ - 5,51 10,51 - 15,51 e 20,51 ppm) e de Cinco de Ferro (15,51 20,51 - 25,51 - 30,51 e 35,51 ppm) Fixando o Zinco na Concentração de 5,45 ppm para o Crescimento de Asper gillus niger $I Z-9$ em Meio de Amido de Mandioca $\quad(3,0$ gramas de Carboidrato por Cento) e Urëia $(0,12$ gramas de Nitrogênio por Cento) ..................... 90

6.4 - Curva de Crescimento do Aspergillus niger IZ-9 em Meio de Amido de Mandioca (3,0 gramas de Carboidrato por Cento), Uréia $(0,12$ gramas de Nitrogenio por Cento), Sulfato de Zinco $(5,45 \mathrm{ppm}$ de Zinco) e Sulfato Ferroso

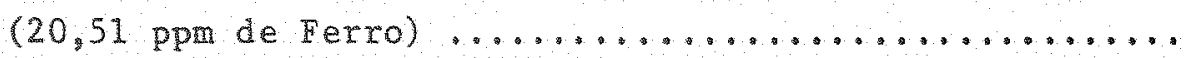

$7-$ CONCLUSÖES

$8-$ SUMARY 


\section{RESUMO}

- presente trabalho teve por objetivo averiguar se o amido de raizes de mandioca possui quantidades adequadas de zinco e ferro para proporcionar o máximo crescimento de um determinado fungo, escolnido para utilizar este substrato como fonte de carbono para a produção de proteina,qua is as doses dos microelementos necessärias à obtenção de tal crescimento e se 0 possivel efeito inibitório de um deles em determinadas concentrações pode ser eliminado ou, pelo menos, reduzido, com a adição do outro.

Dentre os microrganismos ensaiados (Aspergillus niger IZ-9, Aspersillus wentil I2-1625 e Fusarium sp.) os melhores resultados foram alcançados com o Aspergillus niger IZ-9 cultivado em pH 3,0.

Os resultados obtidos quando diferentes doses de ferro e zinco foram adicionadas mostraram que o amido de mandioca da yariedade utilizada (IAC-YARA) não possuỉa concentrações destes elementos em niveis adequados às produções máximas de biomassa e proteina bruta por Aspergillus niger 12-9, as 
quais foram atingidas em concentrações de $20,51 \mathrm{ppm}$ de ferro e 5,45 ppm de zinco. Observou-se que o zinco apresenta efeito tōxico a partir de concen trações em torno de $10 \mathrm{ppm}$ para este microrganismo. Desta maneira, desconhecendo-se os teores de ferro e zinco de raizes de mandioca utilizadas para o crescimento e produção de proteina por Aspergillus niger IZ-9 sugeriuse que fosse adicionado apenas ferro, na concentração em torno de $20 \mathrm{ppm}$, uma vez que este não $\bar{e}$ töxico em concentrações mais elevadas, elimina o efeito inibitörio do zinco e corrige a deficiência do mesmo, se em concentra ções insuficientes. Verificou-se, ainda, que para 0 Aspergillus niger IZ•, cultivado nas condições estabelecidas no presente trabalho, o melhor pH do meio foi encontrado estar em torno de 3 , sendo os valores de pH final a cima de 8 indicadores de mau desenvolvimento do microrganismo. Pelo per- fil de aminoäcidos essenciais encontrou-se que o microrganismo é bom produtor de treonina e que o meio de cultura utilizado deve ser enriquecido com outros componentes, tais como fósforo, potássio, cárcio e magnésio, para que os aminoäcidos essenciais restantes sejam produzidos em maiores proporções e / ou estudos genéticos devem ser realizados a fim de que se obtenham linhagens com capacidade de sintetizar tais aminoäcidos em maiores quantida des, 


\section{INTRODUÇAOO}

A mandioca tem sido, desde a antiguidade, uma fonte de alimento não suficientemente explorada. Possuindo a capacidade de se adaptar a con dições adversas, quanto ao aspecto quỉmico do solo, è competitivamente supe rior a outras culturas de subsistência, principalmente, em paĩses subdesenvolvidos elou em desenvolvimento. O Brasil, sendo o maior produtor mundial destaca-se tambërn como um dos maiores consumidores e um dos que menos participam do processo de exportação. No Nordeste, o cultivo da mandioca atinge cerca de 1.200 .000 hectares, sendo um häbito tradicional que estā, quase na sua totalidade, sob o dominio de pequenos produtores, que fazem desta cultura sua fonte de renda e vida. Ma is de $90 \%$ da produção total se destina a consumo humano, principalmente sob a forma de farinha. Um dos maiores problemas que atingem o produtor reside no esporädico emprego de uma tecnologia industrial que dé à mesma um mérecido valor comercial e nutritivo. Sendo o emprego da farinha de mandioca na alimentação uma tradiçăo que, desde a êpoca que antecede o descobrimento deste pais, foi transmi 
tha de pais para filnos, näo pode ser denolida, em un curto espaço de tempo, con o advent de novas idêlas. Portanto, a utilização de mandioca para produçäo de proteína microbiana não pode afetar o sistema de produção da tradicional farinha, mas tentar oferecer meios de, pelo menos, se apro yeitar os residuos feculentos decorrentes do processo de prensagem que muitas vezes são desperdiçados. A utillização de raízes de mandioca como fonte de carbono para o crescimento de microrganismos pode não só redundar em limentos de valor nutritivo mals elevado como oferecer à cultura uma alter nativa mais nobre, chegando a incentivar a industrialização para fins alinentares que atinjam direta ou indiretamente o homem. Para tal, é necessā pio o emprego de microrganismos que sejam amiloliticos, para evitar gastos com processos de hidrölise, e que se desenvolvam em valores de pH baixos e em temperaturas altas, a fin de minimizar a contaminação. E igualmente importante 0 uso de fungos que, além da proteina de seus micélios, of ereçam simultaneamente, condições para que o liquido residual de suas culturas seja utilizado em indústrias quîmicas e farmacéuticas com a produção de antio xidantes, àcidos organicos e enzimas.

No entanto, alguns problemas microbiolögicos podem surgir acarretando uma baixa produçāo de biomassa e sintese protéica. Um deles pode estar relacionado com as quantidades de microelementos presentes no substra to decorrentes de práticas de adubação utilizadas para aumentar a produção de raiz de mandioca por äres. 0 zinco ten mostrado, dependendo do solo, aumentar a produção, o que leva os técnicos em adubação a utilizá-lo para tal fim. Este pode se acumular nas raizes em al tas ou baixas concentra. çöes dependendo da variedade a ser cultivada. Considerando que a presen- 
ça de micronutrientes em quantidades nắo adequadas pode ser um dos fatores limitantes para o crescimento de microrganismos e que cada um deles exige uma concentração diferente dos mesmos para atingir seu mäximo crescimento, o presente trabaino tem por objetivo averiguar se 0 amido de raizes de man dioca possui quantidades adequadas de zinco e ferro para proporcionar o mä ximo crescimento de um determinado fungo, escolnido para utilizar este substrato como fonte de carbono para a produção de proteĩna, quais as doses dos microelementos necessärias à obtenção de tal crescimento e se 0 possivel efeito inibitório de um deles em determinadas concentrações pode ser eliminado, ou, pelo menos, reduzido, com a adição do outro. 
3. REVISATO DE LITERATURA

A ação de microelementos estimulando ou inibindo o desenvolvimento de microrganismos tem sido amplamente relatada na literatura.

RICHARDS (1899) relata que o ferro tem um duplo efeito sobre o desenvolvimento de fungos, sendo, em determinadas concentrações, um nutriente necessário ao fungo e, em maiores quantidades, um estimulante do crescimento. Em relação ao zinco encontrou um efeito estimulante dentro de certa faixa de concentração, passando a tóxico após atingir determinado nível.

WATTERSON (1904) encontrou que pequenas quantidades de sulfato de zinco, assim como de sulfato fërrico, aumentam a taxa de crescimento e produção de diōxido de carbono por Aspergillus niger e Penicillium glau. cum.

CURRIE (1917) achou que, quando nitrogēnio foi suprido como sais de amônio ou como asparagina para a produção do ácido cítrico por Aspergillus niger, o ferro não estimulou os processos metabólicos. Quando, porém, o nitrogênio foi suprido como nitrato, o ferro teve um efeito esti. mulante acentuado, especialmente notável na produção aumentada de diōxido de 
carbono e peso micelial. A adição de $0,01 \mathrm{~g} / \ell$ de sulfato ferroso, corres pondente a 2 ppm de ferro, ao mejo contendo nitrato estimulou o crescimento do micelio e aumentou a taxa do metabolismo, principalmente nos primeiros dias de fementação, sugerindo que alguma reação quỉmica envolvida na util zação do nitrato ē acelerada na presença de ferro.

STEINBERG (1919) encontrou na literatura uma grande discrepānchà en relação à produção mäxima de biomassa com mỉnima concentração de zin co. Esclarece que esta discrepāncia pode resultar, pelo menos em parte, do uso de linhagens que exigem diferentes quantidades de zinco para seu desenvolvimento ötimo e que a presença de diferentes concentrações de zinco no meio, não levada em consideração, pode ser um fator causal adicional. 0 au tor não cita, porém, um outro fator de grande importāncia que è a composi ção do meio em termos de fontes de carbono e nitrogênio. O metal pode de sempenhar um papel muito importante no mebabolismo destes dois elementos em quantidades diferentes, dependendo da complexidade das duas fontes.

Ainda em 1919, o mesmo autor us ou o método de purificação hidro Titica para estudar a influéncia do zinco e do ferro sobre o crescimento de Aspergillus niger. Verificou que os dois elementos isoladamente não apre sentavam um efeito estimulatório significativo, porēm, quando adicionados ao meio conjuntamente, o fenomeno característico de estimulação do cresci mento era observado. No controle, sem adição de ferro e zinco, ocorreu um pequeno crescimento, o que pode ter sido devido à ineficiència do método em eliminar totalmente estes elementos do meio ou à presença de quantidades apreciáveis dos mesmos no inöculo capazes de promover algum crescimento. 0 Tigeiro aumento observado após adição de ferro e zinco isoladamente se deve 
a lér desses fatores, à impureza dos pröprios sais de ferro e zinco.

MCHARGUE @ CALFEE (1931), estudando o efeito do manganês, cobre e zinco sobre o crescimento e metabolismo de fungos filamentosos, $a b-$ servaram que para o Aspergillus flavus o maior peso micelial foi obtido quando os trés microelementos estavam presentes. Quando tomados isoladamen te, o manganés e o zinco foram os que mais influenciaram na produção de mas sa micelial, sendo o primeiro ligeiramente superior. Tanto para o manganês, cono para o cobre e o zinco, o maior peso micelial foi obtido na concentração de 5 ppm (partes por milhão). Quando combinados lois a dois os me tho res resultados foram obtidos com a combinação manganês - zinco, cuja produção aumentou cerca de 8,6 vezes em relação ao controle (sem adição de microelementos), comparada com cerca de 5,1 vezes para zinco-cobre e cerca de 4,0 vezes para manganēs-cobre. A combinação dos três elementos produziu aproximadamente 9,0 vezes mais que o controle. Em sillica-gel, as concentra çöes ötimas desses elementos para o mesmo fungo foram 5 ppm para o cobre, 2.5 ppm para o manganés e 1 ppm para o zinco. Concordando com a medida tomada em peso seca, a melhor combinação dos elementos foi aquela em que os trēs estavam presentes, seguindo-se a combinação do manganés com 0 zinco. os trés elementos influenciaram a assimilação de fósforo, magnésio e cálcio, send que na presenç de zinco esses elementos foram assimilados em maiores quantidades.

Pesquisando o efeito dós mesmos elementos sobre o crescimento de leveduras, os autores, no mesmo ano, verificaram que para se obter o máxi mo crescimento de Saccharomyces cerevisiae eram necessários 10 ppm de zinco, $10 \mathrm{ppm}$ de manganes e $7,5 \mathrm{ppm}$ de cobre. 0 crescimento foi medido em peso se co e taxa de divisão celular. Quando testados isoladamente, através de medida do peso seco, verificou-se que o cobre produziu melhor crescimento que 
os outros elementos. Através de medida de taxa de divisão celular, o cobre inicialmente inibiu a reprodução, mas com o decorrer da incubação passou a favorecê-la mais que o manganês e o zinco. Estes, separadamente, produzi ram aumentos imediatos na taxa de divisão celular, quando comparados com 0 controle (sem adição de microelementos), e aumento do tamanho das células, enquanto que no meio contendo cobre as células eram pequenas, ligeiramente menores que as do controle. Os autores sugerem que o maior peso das células crescidas em meio com cobre está relacionado com o grande número de pequenas células. Quando estudados em grupos de dois /manganēs e cobre; manganês e zinco; cobre e zinco), o maior peso foi obtido nas culturas contendo manganês e zinco, similamente ao encontrado para Aspergillus flavus. 0 numero de cẻlulas foi praticamente o mesmo nos trēs tratamentos, porém : 0 tamanho das cêlulas foi maior quando o manganês estava associado com o zinco resultando, daî, o maior peso das culturas des te grupo. Quando testados os três elementos em conjunto, as cêlulas se apresentaram ligeiramente menores que as do grupo formado por manganès e zinco, devido à maior taxa de divisão, o que resultou na obtenção do peso mäximo nas culturas em que os três elementos es tavam associados.

PORGES ( 1932) encontrou que a presença de cloreto férrico afetava a produção de ácido cîtrico por Aspergillus niger. A concentração em que a produção de ácido e crescimento do fungo, medido em peso seco, alcançaram o máximo foi de 0,02 gramas de cloreto férrico por litro. Em con centraçōes superiores, tanto a produção de äcido como o crescimento decaîramaté atingir um efeito tipicamente töxico, quando uma concentração de 0,20 , foi usada. Testes com sulfatos de zinco, manganês, níquel e cobre na concentração de $0,01 \mathrm{~g} / \mathrm{h}$ mostraram que apenas o zinco apresentou em efei t estimulatôrio, aumentando tanto a produção de ácido cítrico como a quan 
tidade de acido obtida por unicade de açucar consumido, o que foi acompanha do de ausencia de espor escuros e aumento no desenvolvimento do micélio. os outros elementos foram inititorios na concentração usada. 0 autor conclui que a presença de ferro zinco é essencial para o räpido crescimento e aumento no acumulo de äcido cîtrico. Embora o autor não chame atenção para o crescimento do fungo no mejo onde não foram adicionados ferro e zinco. percebe-se que presenç destes se achava em quantidades suficientes para prowower tanto o crescimento como a produção de äcidos. Níquel, man gănés c cobre podiam estar presentes em quantidades suficientes para pro mover o desenvolvimento ötimo. Assin, quando adicionados ao meio exibiriam efeito coxico devido a concentraça al ta resultante ou, a propria concentra cäo de tais elementos adicionada poderia por si sö ter sido alta, indepen dentemente de uma quancidade existente no meio.

MOSSERAY (1932), analisando o efeit to do zinco sobre värias espë cies do genero Aspergillus e linhagens de Aspergillus niger, verificou que as especies e linhagens estudadas reagem à ação do zinco de maneira bastanto diversa. A presenç do zinco exerceu um aumento no peso dos microrga nismos de duas a ofto vezes em relação à cultura sem zinco. Utilizando três Timhagens de Aspergillus miger (A. niger Church 731 . A. niger Biourge 695 A. niger Gobbe 714$)$ observou diferentes comportamentos tanto no meio contendo zinco, cono naquele sem o elemento. Para o meio contendo zinco, 0 maror peso fol produzido pela limhagem 731 , ficando a 695 numa posição in temediaria a 714 cono menor produtora de biomassa. Para o meio sem zinco, Iinhagen 695 produziv o maior peso, enquanto que a 731 ficou na posicâo intemediaria e a 695 novamente apresentou o menor peso. Apesar da $1 i$ magen $7 / 4$ ter apresentado as mais baixas produções, foi a que se mostrou małs sensivel à a dicão do zinco, sendo a 695 a de menor sensibilidade. 
STEINBERG (1936), na tentativa de desenvolver um método para a completa renoção de metais pesados de meio de cultura para Aspergillus. niger, através de extração alcōolica, chegou à conclusão de que o método era inaplicável para o fim a que se propunha. Aproveitou, então, os dados para estudar a relação entre substäncias acessörias de crescimento e metais pesados na nutrição de A. niger. Verificou que, com ou sem extração, a redução no crescimento do fungo era mais acentuada quando zinco e ferro não eram adicionados. Segundo o autor, a presença de crescimento na omissão de cada elemento se deve à falta de uma remoçào total do mesmo ou ao transporte pelo inöculo de quantidades dos elementos suficientes para promover crescimento, provenientes do meio de cultura anterior 0 método de extração foi capaz de remover zinco em quantidades suficientes para causar uma redução no crescimento de $10,51 \%$ para $4,93 \%$. No entanto, o autor nào leva em consideraçao que esta redução pode ter sido causada nao pela re moção do zinco em si, mas por um desbalanceamento entre os diversos elementos. Em relaçào ao ferro, quando todos os componentes do meio foram subme tidos à extração alcöolica o crescimento do fungo foi maior do que quando não foi usado processo de extração ou quando apenas a sacarose for submetrda ao mesmo. Isto poderia reforçar a hipötese de que a redução no cresci. mento resulta de um desbalanceamento entre os värios elementos. 0 autor achou, ainda, que a linhagem de A. niger estudada parece năo necessitar de substancias acessônias de crescimento, afimando que o aumento no crescimen to ocorrido quando extratos de materiais orgânicos, tais como extrato de malte levedura, foram usados, pode ter resultado da presença de metais pesados. Analisando alguns efeitos de metais pesados essenciais para a nu triçäo de Aspergillus niger sobre seu crescimento, STEINBERG, no mesmo ano, verificou que as taxas de crescimento aumentam com o aumento nas concentra- 
ções de metais pesados até um certo ponto, a partir do qual o aumento nas concentrações leva a quedas progressivas nas taxas de crescimento. Manga nês, ferro, zinco e cobre mostraram ser essenciais tanto para o crescimento como para a esporulação do fungo, podendo a não adição de ferro e zinco reduzir a produção em $98 \%$ ou mais, enquanto que a não adição de cobre e manganès pode reduzir de $60 \%$ ou mais.

Em 1937,0 mesmo autor introduz o fator fonte de nitrogēnio como um possỉvel contribuinte para as variações observadas na utilização de elementos traços por A. niger. Observou que em todas as fontes de nitrogénio utilizadas, a não adição de ferro e, principalmente, zinco reduz sensivelmente o desenvolvimento do fungo. Quando a fonte de nitrogénio era o nitrato, exceto nitrato de cālcio, a omissão de molibdênio causava uma redução no crescimento igual e, às vezes, superior à observada na omissão do zinco. Dos microelementos testados (ferro, zinco, cobre, manganés e molibdénio) os que causaram menos alteração no crescimento, quando omissos, foram o manganés e o cobre. O autor salientou que é necessārio um ajuste correto das concentrações destes componentes essenciais.

Ainda STEINBERG, em 1939, continuando seus estudos sobre os efei tos de elementos traços em diferentes fontes de nitrogênio, encontrou que, a lēm do ferro, zinco, cobre, manganés e molibdēnio, tambēm o gāitio é essen cial para o crescimento de Aspergillus niger Van Tiegh. De um modo geral, quanto maior a deficiéncia menor o crescimento e maior a quantidade de ions residuais inicialmente adicionados. Na maioria das fontes de nitrogénio uti lizadas as maiores reduções na produção de biomassa se devia a não adição do ferro e zinco. As baixas produções causadas pela não adição de ferro eram frequentemente acompanhadas de um aumento na produção de hidroxilamina, enquanto que baixas concentrações de zinco evitavam a formação deste composto. 
Novamente o autor mostrou a redução do crescimento na omissão de molibdénio quand a solução nutriente continha nitratos de lĩtio, södio, potássio e magnésio, salientando que o molibdênio parece ser de especial importáncia para os processos de redução não apenas de nitrato, mas de nitritos e sais de äcido nitrohidroxilaminico.

No mesmo ano, STETHBERG relacionou a inda os efeitos de elemen tos traços necessärios ao desenvolvimento de A. niger Van Tiegh com diferen tes fontes de carbono. Utilizando sacarose, d-glucose, d-frutose, d-manose, d-galactose e 1-sorbose, como fontes de carbono, verificou que a não adição de zinco causou uma grande reduçäo no crescimento quando as quatro primei ras fontes de carbono foram empregadas, enquanto que o ferro reduziu em maior proporção apenas nas duas primeiras fontes. 0 molibdênio produziu uma redução de cerca de $50 \%$ quando sacarose, d-manose e 1-sorbose foram utiTizadas. Manganés, cobre, gälio e escädio apresentaram pouca ou nenhuma a teração no crescimento com estas fontes de carbono, porēm com glicerol 0 escãdio dobrou a produção de biomassa.

FOSTER a WAKSHAN (1939) estudaram o efeito do zinco, ferro, cobre, manganès e molibdênio sobre o crescimento e produção de äcido fumä rico por Rhizopus nigricans. Dos cinco elementos testados isoladamente, 0 zinco foi o que apresentou maior efeito tanto sobre o crescimento como sobre a produção de ácido fumárico. Numa concentração de 1,2 ppm, o zinco modificou a utilização de energía pelo fungo estimulando a produção de mi cêlio aêreo abundante. Quando medido através de consumo de nitrogénio do meio, o crescimento das culturas we continham zinco era 2,5 vezes maior que a da cultura controle (não adição de microelementos). Cobre, manganês e molibdênio isolados näo tiveram efeitos significativos, porém a presença simultānea do zinco levou à resposta característica. Pode-se, assim, 
falar "efeito especifico" do zinco sobre o crescimento do Rhizopus. Os dados sobre a reduçäo de äcido fumärico sugerem a natureza deste efeito. Em culturas contendo zinco a produçà do ácido foi sensivelmente reduzida. Na auséncia deste elemento, o organismo transfomou grande parte da glicose en ácido funärico. O zinco toma o organismo capaz de utilizar sua fonte de camono de maneira mais completa, em vez de deixar grande parte dela pre sa sob a forma de àcido fumárico. Pequénas quantidades deste elemento pare cen catalisar a degradação mais completa da glicose e, consequentemente, sua melhor utilização como fonte de carbono e energia para a sintese celular. 0 ferro apresentou efeito conträrio ao do zinco em relaçào ao crescimento. Quando usado isoladamente tendeu a deprimir o crescimento, porém a capacida de de produzir äcido fumárico näo foi reduzida. Quando combinado com zinco - efeito do ferro foi não apenas inibido, mas o efeito especifico do zinco foi até mesmo acentuádo. o justamento da razão $\mathrm{Fe}$ : In pode reduzir o efej to especifico do zinco, sendo a resposta característica do organismo ao fer ro manifestada, ou seja, ocorre uma parcial neutralização dos dois elementos. Portanto, deve ser enfatizado que a natureza antagonica ou associativa desses dois elementos depende da sua razão.

Através de uma revisäo bibliogräfica sobre os metais pesados na nutrição de fungos. FOSTER (1939) conclủu que não hä düvida de que a necessidade por quantidades traços de värios metais pesados, tais como zinco, ferro, manganès, cobre e, possivelmente, outros ë um fenómeno amplamente encontrado entre os fungos e, especialmente, entre os filamentosos, para os quais esses elementos devem ser considerados indispensäveis. Salientou que a maioria dos estudos ë feita com Aspergillus niger e que, certamente, outros fungos têm diferentes necessidades por metais pesados, não sendo 0 papel de um determinado metal o mesmo para värios organismos. 
BLANK (1941), numa tentativa de desenvolver o melhor meio pos sível para o crescimento de Phymatotrichum omnivorum, realizou värios experimentos para determinar que elementos são necessārios para o crescimento ötimo e em que proporções. Cobre, ferro, manganês e zinco foram estudados intensivamente, parecendo que pelo menos os três ültimos são essenciais para o crescimento ótimo do organismo em estudo. Dados preliminares revela ram que esses elementos eram exigidos em concentrações muito mais altas que as encontradas para vārios organismos estudados por outros pesquisadores. Os resultados de trés experimentos fatoriais, para determinar o efeito da presença ou ausência de cobre, ferro, manganēs e zinco, em soluções purificadas, mostraram que o cobre foi um tanto benéfico a 2 ppm,indiferente a 5 ppm e causou uma ligeira depressão no crescimento a 10 ppm; com ferro, manganês e zinco presentes houve aumento acentuado no crescimento, muito maior que a somatōria de seus efeitos individuais, indicando a existência de interações muito importantes; as melhores interações foram obtidas para as combinações ferro-zinco e manganês-zinco. Em soluções não purificadas os resultados foram iguais ou superiores aos obtidos com soluções purificadas, tendo sido omitida a adição de cobre, sendo ferro, manganês e zinco empregados aproximadamente nas mesmas razōes. A solução não purificada foi extremamente sensível à adição de cobre e muito mais sensível a concentra ções crescentes de ferro e, principalmente, zinco que a solução purificada. Em experimentos posteriores, nos quais ferro e zinco variaram em quatro diferentes nî̉eis e manganês mantido constante em 2 ppm, a importāncia dessas taxas relativas tornou-se mais evidente e os efeitos prejudiciais resultantes de uma condição não balanceada foram enfatizados, principalmen te os efeitos inibitörios de concentraçōes aumentadas de zinco em relação à concentração do ferro. Foi observado um efeito depressivo do ferro a 
10 pm, em solução não purificada, tendo praticamente desaparecido a concen traçoes mais altas.

Trés novos isolados de Phymatotrichum omnivorum foram compara dos entre si e com a linhagem anteriormente testada para determinar se todos os isolados uti\}izavam igualmente bem os elementos tidos como necessä rios para o crescimento ötimo. Os resultados mostraram que esses isolados podiam ser distinguidos pela taxa de crescimento e capacidade de utilizar diferentes combinações de ferro, manganēs e zinco.

PERLMAN et alii (1946) estudaram o efe ito de ions metālicos so bre a produção de äcido cîtrico por cinco linhagens de Aspergillus niger $(59,62,69,70$ e 72$)$ em dois diferentes meios: Meio A: $140 \mathrm{~g} / 1$ de sacarose, $1,0 \mathrm{~g} / \mathrm{l}$ de $\mathrm{KH}_{2} \mathrm{PO}_{4}, 0,25 \mathrm{~g} / 1$ de $\mathrm{MgSO}_{4} .7 \mathrm{H}_{2} \mathrm{O}, 2,25 \mathrm{~g} / \mathrm{l}$ de $\mathrm{NH}_{4} \mathrm{NO}_{3}$, $0,232 \mathrm{~g} / \mathrm{l} \mathrm{HCl}$, para ajustar o pH para $2,3,18 \mathrm{y} / 1 \mathrm{MnCl}_{2}, 4 \mathrm{H}_{2} \mathrm{O}, 62 \mathrm{\gamma} / \mathrm{l}$ $\mathrm{CuSO}_{4} \cdot 5 \mathrm{H}_{2} \mathrm{O}, 5 \mathrm{y} / \mathrm{\textrm {ZnSO } _ { 4 }} \cdot 7 \mathrm{H}_{2} \mathrm{O}$ e $162 \mathrm{y} / \mathrm{T} \mathrm{\textrm {FNH } _ { 4 }}\left(\mathrm{SO}_{4}\right)_{2} \cdot 12 \mathrm{H}_{2} \mathrm{O}$; Me io B: $140 \mathrm{~g} / 1$ sacarose, $1,0 \mathrm{~g} / 1 \mathrm{~K}_{2} \mathrm{HPO}_{4}, 0,23 \mathrm{~g} / 1 \mathrm{MgSO}_{4} .7 \mathrm{H}_{2} \mathrm{O}, 2,23 \mathrm{~g} / 1 \mathrm{NH}_{4} \mathrm{NO}_{3}$,

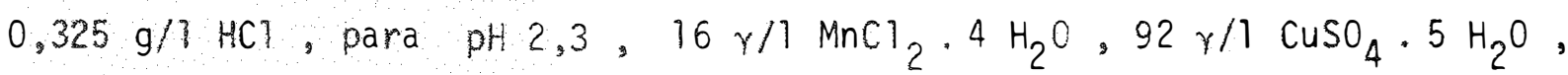
$102 \mathrm{r} / 1 \mathrm{FeNH}_{4}\left(\mathrm{SO}_{4}\right)_{2} \cdot 12 \mathrm{H}_{2} \mathrm{O}$. Com o meio $A$, variando apenas as concentrações de sacarose de 100 a $200 \mathrm{~g} / \mathrm{l}$, verificaram que para a linhagem $\underline{A}$. niger 62 , concentrações de sacarose acima de $140 \mathrm{~g} / \ell$ reduziram a produção de ácido cítrico e adiçăo de $0,1 \mathrm{mg}$ de ferro a este meio pareceu dar ótimos resultados independentemente da concentração de sacarose original. Com o meio B, para as iinhagens $62,69,70$ e 72 , a concentração ōtima de ferro ficou entre 0,1 e 1,0 ppm, enquanto que, para a linhagem 59, a concentração ötima foi de $10 \mathrm{ppm}$. Os efeitos do ferro, manganés, alumỉnio, molibdênio, cobre, zinco, cảlcio e crômio foram testados no meio $A$. Nestas condições, apenas aluminno, crômio, ferro e manganẽs foram estimulatörios para a produção de äcido citrico. 0 zinco foi inibitörio em todas as concentrações testadas. 
As produçöes obtidas quando o ferro foi associado a outros elementos estimulatōrios, em geral, não form melhores que as obtidas quando o ferro foi usado isoladamente. Entretanto, combinações de ferro e manganès, no meio $B$, deram melhores produções que os dois elementos isolados. No meio A, o ferro foi um tanto inibitörio para a linhagem 72 , enquanto que para a $1 i$ magem 62 foi nitidamente estimulatörio; o manganês foi inibitōrio para a linhagem 72 a niveis mut to baixos.

SHU e JOHNSON (1948), analisando a produção de àcido cîtrico por Aspergillus niger em fermentaçäo submersa, observaram que o processo po dia ser dividido em duas fases distintas. A primeira era caracterizada pe10 crescimento micelial onde o açücar era utilizado principalmente para 0 desenvolvimento do fungo e a outra pela paralisação do crescimento e utilização da maior parte do açücar para a sintese de ācido cỉtrido. Dependendo da dose de microelementos utilizada maiores produções de crescimento ou āci do cỉtrico podem ser obtidas. Foi observado que o peso micelial varia diretamente com a concentração de ferro. Em baixos niveis deste elemento a $\underline{u}$ tilização do açücar é pobre por causa do crescimento deficiente resultante. Por outro 1ado, em altas concentrações o abundante crescimento pode deprimir a produção de àcido devido à quantidade aumentada de açūcar utilizada para o crescimento. O autor explica, ainda, que o decréscimo na produção de äcido cîtrico nestas condiçôes pode ter sido devido a diminuição de ar disponivel causada pela alta viscosidade do meio quando tal crescimento ocor re. A concentração ötima de ferro para a produção de ácido cỉtrico foi encontrada ser de aproximadamente $1 \mathrm{mg} / \mathrm{m}$.

No mesmo ano, os autores estudando a interdependência dos constituintes do meio na produção de äcido citrico em culturas submersas, 
mostraram que também o zinco era essencial para o processo. De dez linhagens de Aspergillus niger cultivadas em meio com e sem adição de zinco apenas uma não aumentou a produção de ácido em decorrência da adição de zinco, enquanto que a medida do peso micelial revelou um aumento no crescimento de 2,5 a 7,5 vezes. Como os autores testaram apenas uma quantidade de zinco, é possível que a variação apresentada tanto na produção de ácido como de massa micelial seja decorrente do fato das diversas linhagens exigirem o mi croelemento em diferentes concentrações. Por exemplo, a linhagem que menos produziu ácido e biomassa no meio sem zinco foi a que mais respondeu à adição de elemento tanto para a produção de äcido como de biomassa, enquanto que a que produziu mais ácido apresentou um aumento mui to menor.

FOSTER e DENISON (1950), estudando o papel do zinco sobre o metabolismo de Aspergillus niger e Rhizopus nigricans, verificaram que, quan do pesos iguais de inóculos de micélios provenientes de meios de cultura sem e com zinco eram cultivados em meio contendo o elemento, aqueles origina dos de culturas com zinco atingiam rapidamente a taxa de crescimento máxima. O inöculo proveniente do meio deficiente, no entanto, sempre exigia 10 a 15 horas a mais para atingir sua taxa máxima de crescimento. Segundo os autores, is to indica que o zinco iônico faz parte de uma combinação orgānica ou que o mesmo è necessärio para a síntese de alguma substāncia limitante de crescimento e que esta sintese ocorre durante a fase lag observada. Extratos de micélio proveniente de culturas contendo zinco, extrato de levedura e outros materiais naturajs, dialisados e não dialisados, não encurtaram esta fase, indicando que a substância essencial era uma grande molécu la e, provavelmente, termoläbil. Analisando o efeito da deficiencia do zin co sobre a carboxilase pirúvica de R. nigricans mostraram que em numerosos casos o micélio deficiente em zinco nunca evoluỉa $\mathrm{CO}_{2}$ a não ser em taxas des 
preziveis, enquanto que micêlio proveniente de culturas con zinco evoluia grandes quantidades, o mesmo acontecendo com caldo livre de células. A adi ção de cocarboxilase, zinco e magnésio ao caldo de micëlio deficiente não produziu qualquer atividade carboxilase pirúvica. Pareceu provável que a carboxilase pirúvica era a substância responsāvel pelo maior tempo observado na fase lag do micélio deficiente. Pelos resultados obtidos verificaram que o zinco era essencial para a sintese da carboxilase pirúvica em Rhizo pus nigricans embora haja indicação de que o metal não faz parte da enzima.

TOM INSON et alii (1950), analis ando a influencia do zinco, fer ro, cobre e manganês sobre a produção de ácido cítrico por Aspergillus niger, testaram, inicialmente, duas doses $(0,005$ e $0,7 \mathrm{mg} \%)$ dos elementos e verificaram que apenas o zinco mostrou uma diferença marcante tanto na prodeção de ácido como de micélio seco, sendo a concentração de $0,1 \mathrm{mg} \%$ a meThor. Fixaram, então, esta dose de zinco e variaram as doses de ferro,ten do encontrado que para a produção de àcido cítrico a melhor concentraçào fí cou em torno de $0,01 \mathrm{mg} \%$, enquanto que para peso seco as me thores produçães foram obtidas na faixa de 0,03 a 0,1 mg $\%$. Mantendo a concentração de zinco em $0,7 \mathrm{mg} \%$, fixando a de ferro em $0,01 \mathrm{mg} \%$ e variando as de cobre e manga nès, isoladamente, encontraram que em relação ao cobre as me thores produçōes para ácido cîtrico foram obtidas quando concentrações na faixa de 0,01 a $0,1 \mu g \%$ foram empregadas, enquanto que para a produção de micélio não foi encontrada variação na faixa de 0,01 a $5,0 \mu g \%$. Em relação ao manganès a melhor faixa para ácido cîtrico foi de 0,07 a $0,149 \%$ e para peso seco de 1,0 a $5,0 \mathrm{~kg} \%$. Quando os quatro elementos foram adicionados juntos, sendo 0,1 mg $\%$ de zinco, $0,01 \mathrm{mg} \%$ de ferro e concentrações de 0,01 a $5,0 \mu 9 \%$ de cobre e manganês, observaram que as melhores produções do ācido foran obtidas nas concentrações de 0,01 e $0,1 \mu \mathrm{g} \%$ de cobre e manganès, enquanto que 
para peso seco as melhores concentrações foram de 1,0 e 5,0 $\mu$ g\% destes elementos. Fixando o zinco em $0,7 \mathrm{mg} \%$ e o ferro numa concentração encontrada, anteriormente, como ōtima para produção de biomassa $(0$, Img $\%)$ e utilizando duas doses de manganēs e cobre $(0,1$ e $5,0 \mu \mathrm{g} \%)$, encontraram uma maior produção do ăcido com 0,1 ug\% dos elementos e de biomassa com 5,0 ug\% dos mesmos. Ficou evidente que, de um modo geral, as quantidades de ferro, cobre e manganês exigidas para uma alta produção de äcido cítrico são menores que aquelas necessärias para o bom desenvolvimento do microrganismo.

NASON (1950) verificou que a sintese de triptofano em extratos livres de cêlulas de Neurospora provenientes de micêlio deficiente em zinco era prejudicada e mostrou que parece haver uma relação entre zinco e a enzima que converte indol e serina em triptofano. 0 autor esclarece que não se sabe se o zinco é um constituinte enzīmico ou se está relacionado direta ou indiretamente com a sintese de um ou mais constituintes do sistema enzĩmico.

NASON et alii (1951) encontraram alterações na constituição en zimica de Neurospora deficiente em zinco. Os resultados de cinco experimentos foram similares em relação ao tipo de distribuição enzỉmỉca. Em quatro dos experimentos, nenhuma atividade äl cool desidrogenase foi detecta da nos extratos deficientes em zinco e apenas um apresentou traços de ativi dade em relação ao controle suficiente em zinco. A adição de zinco ao extrato deficiente não restaurou a atividade da ä cool desidrogenase. Da mes ma forma, a adição de extrato deficiente ao extrato controle não a terou em nada a atividade enzimica do úttimo, sugerindo que a perda da atividade enzĩmica em Neurospora deficiente em zinco não se deve à presença de inibidores, mas à falta da enzima. Houve também um decréscimo no teor da enzima que condensa indol e serina para a formação de triptofano em homogeni- 
zado total de Neurospora deficiente em zinco e seu respectivo extrato. Es te decréscimo não foi tão marcante quanto o ocorrido com a atividade da ā?cool desidrogenase, porém foi frequentemente observado. A adição de zinco a extratos deficientes não afetou a síntese do triptofano. Ao conträrio do que se observou para estas duas enzimas, a deficiēncia em zinco resultou nu ma acentuada elevação no teor de NADase (nicotinaminada-adenina-dinucleotidase), sendo o aumento de 10 a 20 vezes por miligrama de proteína quando comparado com extratos normais. A adição de zinco a extratos deficientes não diminuiu a atividade desta enzima. Não foi detectado nenhum estimula dor para a sua sintese em extratos deficientes, nem inibidor no extrato con trole. Os autores verificaram, ainda, que a atividade da fumarase de Neurospora aparentemente não foi áfetada pela deficiēncia em zinco e que as enzimas hexoquinase, aldolase e triosefosfato desidrogenase estão presentes em homogenizado e extrato de Neurospora deficiente em zinco em concentrações normais. Em relação ao crescimento do microrganismo nos cinco experimentos houve uma redução nos meios deficientes em zinco que variou de 37 a $59 \%$ em comparação com o observado nos controles. Testando as doses 0-0,02$0,10-2,0-20-100$ e $600 y$ de zinco por mililitro de meio, os autores verificaram que a dose le $2,8 \mathrm{\gamma} / \mathrm{m}$ foi a que maior percentagem de crescimento proporcionou. As deficiências de outros elementos (manganès, ferro e magné sio) foram testadas. A omissào de manganès e ferro aparentemente teve muito pouco efeito sobre a concentração das enzimas estudadas, enquanto que a deficiência de cälcio resultou numa perda de atividade da âlcool desidrogenase, um aument significante na concentração de NADase e não pareceu baixar o nível de enzima sintetizadora do triptofano. A deficiência em magnésio produziu ligeiras reduções na ālcool desidrogenase e na enzima sintetizadora de triptofano em relação ao controle, porém estas variações não pare 
ceram ser significantes. Os autores conclứram que a deficiéncia de zinco em Neurospora leva não simpiesmente à produção de menos micêlio, mas de micelio com caracteristicas me tabölicas drasticamente alteradas, as quais envolvem, além de desaparecimento virtual de certas atividades enzimicas, aumentos acentuados na atividade de outras enzimas. As concentrações de certas proteinas enzimicas dentro da cêlula diminuem, enquanto que outras aumentam. Determinaçóes do teor de proteina total nos extratos mostraram aue o efeito Tíquido é um profundo decréscimo na concentração de proteina. Una vez que este quadro não se modifica pela adição de aminoácidos, purinas, pimiminas e vitaminas ao meio deficiente em zinco parece que o efeito bả sico da defictência está nào na sintese destas unidades mas em seus metabo Hismos subsequentes. Se 0 zinco está relacionado diretamente com o processo de incorporação de aminoácidos em proteínas ou se seu papel neste proces so é o resultado da açào em outro șitio, o fato é que o principal resultado da deficiencia de zincoé a falta de sintese de proteinas enzimicas de uma maneira normal. o mecanisno pelo qual as concentraçōes de certas enzimas podem ser aumentadas em cēlulas nutricionalmente deficiente ainda é des connecido. Os autores levantaram a nipötese de que estas enzimas são pro teinas de estruturas relativamente simples que podem ser sintetizadas mesmo na auséncia de certas reaçóes chaves que são necessárias para a síntese de moléculas proteicas mais complexas.

VALLEE e NEURATH (1955) encontraram que o zinco é um componen te estrutural e funciona\} da carboxipeptidase e participa nos mecanismos de sua ação catalîtica. O metal se acha ligado firmemente à proteinna e parece ser indispensävel para a atividade enzimica.

WACKER e VALLEE (1959) detectaram a presença de quantidades significantes de metais (magnèsio, cálcio, estrōncio, bärio, alumínio, crō- 
mo. manganés, ferro, nĩquel, cobre e zinco) em RNA de diferentes fontes, desde microrganismos até vertebrados biologicamente complexos. Os autores sugerem que eles podem desempenhar um papel na manutenção da configuração da molécula de RNA, talvez ligando bases de purina ou pirimidina, ou ambos, atrâes de ligações covalentes. Também foi detectada a presença de metais em DNA, porém em quantidades mui to menores.

PATTERSON (1960) mostrou que um suplemento de cálcio, cobre, cobalto e zinco triplicou o crescimento de Mycobacterium tuberculosis avium e aumentou a produção de porfirina de cerca de 62 vezes apös 45 dias de incubação. A adição de quantidades iguais de zinco ou cobalto ao meio, separadamente, também estimulou tanto o crescimento quanto a produção de porfirina, mas em qualquer caso o efeito foi apenas cerca da metade do induzido pelo suplemento completo. o cobre sozinho não teve nenhum efeito nem no crescimento nem na produção de porfirina. o autor conclui que o efeito do suplemento completo é em grande parte, se não unicamente, devido ao zinco e cobalto.

PRICE e VALLEE (1962) verificaram que a não adição de zinco diminuia acentuadamente o crescimento de Euglena gracilis. Partindo de doses crescentes de 0 a $16 \mu \mathrm{g} / 1$. obtiveram uma relação linear, exceto no estāgio inicial do crescimento. Comparando o desenvolvimento do microrganismo num meio contendo $10^{-5} \mathrm{M}$ de zinco com o ocorrido sem adição do elemento verificaram que após 8 dias e meio a cultura deficiente em zinco paralisou seu crescimento. No entanto, a adição de $10^{-5} \mathrm{M}$ do elemento no sétimo dia restau rou o crescimento apös 24 horas, atingindo o mesmo nivel da cultura sem deficiencia de zinco aos 11 dias. Esta resposta revelou que a paralização no crescimento não se deve ao àcúmulo de substâncias tóxicas mas à exigência do metal. Os autores não chamam atenção,porëm, na cultura deficiente em zinco, 
para o tempo que a alga levou para reiniciar seu räpido crescimento apös a adição do metal. Is to pode revelar que o zinco é necessārio para a sintese de substâncias indispensāveis ao bom desenvolvimento do microrganismo e que, pelo menos, uma destas substāncias é sintetizada na fase inicial do crescimento. As anälises de nitrogênio revelaram resultados contrārios aos obser vađos em relação ao crescimento. A percentagem de nitrogềnio total nas células deficientes em zinco foi o dobro da das cêlulas sem deficiência na fa se exponencial do crescimento e aproximadamente o triplo daquelas da fase es tacionäria. Comparando os teores de metais das cêlulas com o teor de metal total do meio, os autores observaram que com exceção do zinco, cobre e ferro, a concentração de metais encontrada nas cēlulas representou pequenas frações dos metais totais adicionados ao meio. Como ferro e cobre não foram limitantes para o crescimento em concentrações muito baixas pareceu pro vävel que apenas o zinco foi limitante para o crescimento do microrganismo.

WACKER (1962), estudando as alterações no teor de äcidos nuclei cos, proteinas e metais em Euglena gracilis decorrentes da deficiência de zinco, verificou que quando este organismo foi desenvolvido na auséncia de luz e num meio contendo $1,5 \times 10^{-7} \mathrm{M}$ de zinco o desenvolvimento foi marcadamente reduzido comparado com a cultura crescida no escuro no meio normal, on de 0 teor de zinco era $1,5 \times 10^{-5} \mathrm{M}$. A adição de zinco à cultura deficiente restaurow o crescimento normal. O mesmo não ocorreu quando outros metais, aminoācidos, bases nitrogenadas ou nucleotideos foram adicionados. Concordando com os trabalhos de PRICE e VALLEE (1962), anteriormente citados, o au tor achou que a deficiência de zinco è acompanhada por alterações importantes no teor de proteina e ácido nucleico dos organismos, as quais consistem de uma redução na sintese protêica, indicada por um aumento em precursores de proteỉna como, por exemplo, aminoácidos, e um decréscimo em RNA. Em con 
sequência,ainda, da deficiência em zinco há um aumento no volume e peso das cêlulas individuais, chegando a aumentar aproximadamente cinco vezes em rela ção às células crescidas em meio zinco-suficiente, e duplicação do teor de DNA, o que demonstra uma paralização mitōtica. Baseado nos dados obtidos, o autor enfatiza que não se pode afirmar sem erro que os efeitos observados sobre o metabolismo das proteînas e ácidos nucleicos derivam diretamente da deficiência do microelemento no RNA desses microrganismos. Como o zinco faz parte de um grande nūmero de enzimas, é possivel que a sua falta leve a uma alteração no sistema enzỉmico acarretando defeitos na síntese de algum componente do processo de elaboração da proteína. 0 fato da adição de aminoācidos, purinas, pirimidinas ou seus nucleotídeos não superar os danos causados pela deficiência sugere que estes não se dão apenas sobre a sintese de precursores, mas sobre a sintese de proteina propriamente dita. Os efeitos da deficiência de zinco não comprometem simplesmente o metabolismo oxidativo no sentido de não fornecer energia suficiente para o processo de sintese proteica, uma vez que hä um grande acūmulo de polifosfato ácido-insolūvel, chegando a constituir uma das principais características das cēlulas deficientes. Como o polifosfato se origina de moléculas de ATP pode-se deduzir que os sistemas geradores de energia estão funcionando eficientemente. O autor salienta que a identificação e localização de defeitos mole culares induzidos por deficiéncia em zinco parece possível e, desta maneira, pode-se chegar a uma conclusão a respeito do papel de metais no RNA.

TRUMPY e MILLIS (1963), estudando a produção de äcido cîtrico por um mutante de Aspergillus niger, afirmam que o acúmulo de grandes quantidades deste ácido é resultante de uma função metabōlica prejudicada do fungo num meio ácido com alto teor de açücar e com concentrações altamentecontroladas de outros nutrientes. Mostraram tambëm que deficiências nutri- 
cionas mütiplas, como de nitrogēnio, fósforo, zinco e ferro, são de grande importancia por limitar o crescimento, uma vez que este deve ser controTado para se obter uma boa produção de äcido. Embora o crescimento deva ser linitado, isto, por sî sō, não ë suficiente para dar altas produções de äcido cîtrico. E necessäria a presença de baixas concentrações de certos metais traços. 0 mutante de A. niger para a produção de äcido cítrico utilizado foi muito mais sensivel ao zinco que ao cobre, ferro e manganés. Suportou maiores concentrações de microelementos que a linhagem paterna, po rểm a produção de àcido foi maior em aixas concentrações dos elementos, sendo o zinco o mais crîtico. Os autores deixaram claro que a ação do zinco en concentrações mais elevadas, pelo menos para este mutante, è normalizar as funçōes metabölicas. Outros componentes do meio também podem exercer a mesma ação. O ferro em concentrações altas pode minimizar o efeito depressivo do zinco sobre a produção do äcido.

WEGENER et alii (1967), num estudo sobre o controle da formação de malato sintetase em hizopus nigricans, verificaram que o zinco exer ce um notavel efeito sobre o crescimento e atividades fisiológicas deste microrganismo. A adição de glicose ao meio de nidrolisado de caseína causou uma repressão na formação da enzima, a qual foi suprimida pela adição de zinco. Este elemento não teve nenhum efeito significativo sobre a formação da enzima quando adicionado isoladamente ao meio basal de hidrolisado de caseina. Entretanto, combinado com a glicose resultou na produção de malato sintetase num nive? equivalente ao encontrado na cultura não repri mín. Além disso, o metal levou a uma quase completa utilização da glicose a a um aumento na sintese celular, indicando que o zinco suprime a repressão pela glicose efetuando a remoção da catabólitos repressores provenientes da mesma pela estimulação da incorporação de tais metabólitos em material ce- 
lular. Foi determinado o nível da malato sintetase formada num meio sintético, que favorece a formação de ăcido fumárico, contendo $5 \%$ de glicose e $0,2 \%$ de sulfato de amōnio, portanto uma alta relação carbono/nitrogênio. Os resultados obtidos nas culturas com e sem adição de zinco mostraram que a adição do metal duplicou a produção da enzima, aumentou o peso celular e esgotou totalmente a glicose adicionada indicando, novamente, que o aumento no nível da enzima foi produzido, provavelmente, pelo incremento na utiliza ção de glicose e sintese celular provocado pela adição do metal. Assim, parece que fatores que estimulam a sintese celular e remoção de glicose ou seus catabōlitos favorecem a formação da malato desidrogenase. Com base nisto, seria de se esperar que um aumento na fonte de nitrogênio disponível e um ajuste na relação $\mathrm{C} / \mathbb{N}$ para um valor mais favorävel à sintese celular resultassem num aumento da formação desta enzima. Usando concentrações de sulfato de amōnio de 0,2 a $2 \%$ os autores obtiveram aumentos gradativos atin gindo cerca de três vezes mais enzimas na concentração de $2,0 \%$, quando comparada com a de 0,2\%. A adição de zinco aumentou ainda mais, tendo duplica do a produção alcançada nas culturas com 2,0\% de sulfato de amōnio e sem zinco. Analisando o efeito do acetato e do glicolato, ambos encontrados co mo estimuladores da formação da malato sintetase em muitos organismos, observaram que o acetato adicionado ao meio basal duplicou a produção em rela ção ao meio basal sem acetato, enquanto que o glicolato aumentou aproximada mente cinco vezes. 0 efeito indutivo do acetato aumentou significativamente quando zinco foi adicionado. O mesmo não ocorreu, porém, com a adição do metal ao glicolato. Esta diferença de comportamento sugeriu a possibil dade de haver no microrganismo em estudo, duas enzimas malato sintetases re guladas por vias diferentes. Através da inativação térmica foi comprovada a presença das duas enzimas, sendo a induzida pelo acetato mais sensivel ao 
calor que a induzida pelo glicolato.

PECIULIS et alii (1969) encontraram que cobalto, ferro, iodo, manganès, molibdénico e zinco estimulam a propagação de leveduras, enquanto que boro apresenta um efeito inibitōrio. A biossíntese de proteínas é afetada de diferentes maneiras. Alguns microelementos estimulam consideravelmente o aumento no teor de nitrogénio total, como o molibdénio e o zinco, outros a um grau menor, como o cobalto, o iodo e o manganés e, ainda,outros reduzem a quantidade de nitrogénio total, como o ferro a partir de 0,02mg/1 e o boro a partir de $0,0115 \mathrm{mg} / 1$. Sobre a biossintese de aminoācidos os microelementos também influenciam diferentemente não alterando sua composição quîmica mas reduzindo sua quantidade. O zinco reduz o teor de aminoácidos livres a mais da metade, inclusive de aminoácidos dicarbōnicos, arginina, cistina, asparagina e ācido glutämico. 0 molibdénio reduz consideravelmente o acúmulo de aminoācidos dicarbōnicos, alanina e lisina. Por outro lado, tanto o zinco como o molibdēnio produzem um aumento no acúmulo de aminoäcidos ligados, indicando que esses microelementos estimulam a incorpo ração de aminoäcidos em proteinnas. Além disso, os autores verificaram que leveduras crescidas em licor sulfitico produziram maiores quantidades de äcido fölico, tiamina e riboflavina quando determinadas concentrações de manganês, cobalto, molibdēnio, boro e zinco eram adicionadas, sendo o aumento de $26-52 \%$ quando comparado com um controle. Quantidades excessivas dos micronutrientes foram tóxicas tanto para o crescimento das leveduras co mo para o acumulo de proteinas e vitaminas.

SANCHEZ-MARROQUTN et alii (1970) verificaram que uma maior pro duçăo de ácido ç̃trico por Aspergillus niger foi obtida quando ferro, zinco e cobre estavam presentes em baixas concentraçóes, enquanto que uma maior produção de massa micelial ocorreu quando concentrações mais elevadas dos 
três elementos foram empregadas. Estes dados estão de acordo com resultados apresentados por outros pesquisadores anteriormente citados.

MCHAN e JOHNSON (1970), analisando a importāncia do zinco e de aminoäcidos para o crescimento de Monascus purpureus, verificaram que interações do zinco com aminoācidos em meio mínimo onde glicose foi também uma fonte de carbono levando a um aumento no crescimento do microrganismo eram repetidamente notadas. Doze dos quatorze aminoäcidos e todas as combi nações de aminoācidos testadas em meio mĩnimo com adição de zinco produzi ram crescimentos significativamente maiores que os obtidos com os mesmos meios sem adição de zinco. Além disso, os ligeiros efeitos inibitōrios de vārias combinações de aminoácidos ocorridos na ausēncia do zinco tenderam a desaparecer na presença do microelemento. Alguns aminoācidos estimularam mais o crescimento que outros, porém quase todo efeito estimulatōrio foi aumentado pela adição de zinco. Os autores concluem que, além dos possí veis efeitos sobre o metabolismo dos carboidratos, os principais efeitos do zinco estão também envolvidos com os mecanismos regulatōrios que controlam interrelações entre os metabolismos dos carboidratos e do nitrogēnio em $M$. purpureus.

WHITE e JOHNSON (1977), cultivando Helminthosporium cynodontis em meio de glicose-peptona-extrato de levedura agar (GPY) e Czapek -Dox, observaram uma grande diferença no crescimento e pigmentação das culturas. No meio de czapek-Dox, o micêlio se apresentou distintamente vermelho devido à produção abundante de cinodontina, enquanto que no meio GPY ocorreu um maior crescimento sem produçäo deste pigmento, mesmo apōs 50 dias de incuba çăo, aparecendo, em seu lugar, uma coloraçào verde-escura mais característi ca da maioria das espécies de Helminthosporium na maior parte das condições culturais. Na composiçăo do meio GPY estäo presentes peptona e extrato de 
levedura, os quais estão ausentes no meio de Czapek-Dox. Assim, peptona, extrato de levedura e suas respectivas cinzas foram adicionados ao meio basal de Czapek-Dox, isoladamente e em vārias combinações, para se determinar qual ou quais componentes modificam o meio de Czapek-Dox de modo a reproduzir alguns efeitos observados no meio GPY. A adição de extrato de levedura aumentou o crescimento de mais de 2,5 vezes em relação ao controle, em cinco dias, e inibiu completamente a produção de cinodontina. A adição de peptona também aumentou o crescimento, porém não tanto quanto o extrato de levedura e aumentou a formação de pigmento. Quando cinzas de extrato de leve dura foram adicionadas isoladamente ou em combinação com cinza de peptona foram obtidos resultados praticamente similares aos observados quando da adição de extrato de levedura, sugerindo que metais.e, particulamente, os presentes no extrato de levedura, são reponsāveis pelo tipo de crescimento obtido no meio GPY. Sete elementos foram testados, dentre os quais ferro a zinco, Os metais foram adicionados, individualmente e em vārias combinações, ao meio de Czapek-Dox para se averiguar seus efeitos sobre a linhagem RPP de Helminthosporium cynodontis. Em todos os casos em que o zinco foi adicionado, tanto isoladamente como em combinação com um ou mais elementos, o crescimento foi significativamente aumentado e a cinodontina completamente ausente. A adição de ferro ou boro diminuiu ligeiramente o crescimento, en quanto que cobre e cobalto reduziram consideravelmente o desenvolvimento do fungo. Tanto o cobre como o cobal to se apresentaram töxicos nas concentrações usadas quando adicionados isoladamente, porém esta aparente toxicidade foi marcadamente reduzida na presença de outros ions metālicos, particularmente o zinco. Ferro, cobre cobalto nào apresentaram efeito significativo sobre a produção de pigmento, ao passo que o boro aumentou ligeiramente o teor do mesmo. O manganēs, isoladamente, pouco efeito exerceu sobre o cresci 
mento, porēm aumentou ligeiramente a pigmentação. Em combinação com o zinco, o manganês elevou o efeito promotor de crescimento do zinco de aproxima damente $100 \%$ em relação ao meio contendo apenas zinco. Os resultados mostraram que o zinco é o principal responsāvel pelos efeitos do meio GPY e do extrato de levedura sobre a linhagem RPP de $\underline{H}$. cynodontis. 0 estudo de diferentes concentrações de zinco ( 0 a $12,2 \mu M)$ sobre a sintese de pigmento e crescimento do fungo revelou que o aumento no teor de zinco diminuiu a produção do pigmento, chegando a quase desaparecer em concentrações de 6,1 wM, e aumentou o crescimento celular. A taxa de consumo de glicose e fosfato se apresentou aumentada na presença de zinco, confirmando dados relatados por outros pesquisadores.

COCUCCI e ROSSI (1972) mostraram, através de dados bioquīmi cos e morfolögicos, que o zinco é essencial para o crescimento de Rhodoto rula gracilis, sendo seus efeitos mais marcantes as sinteses liquidas de RNA e proteîna. A síntese de DNA pareceu não ser muito afetada. A adição do microelemento a culturas deficientes não estimulou nem inibiu a respiração, metabolismo de aminoācido e síntese de îpídeos. Estes resultados sugerem um efeito específico do elemento sobre as sinteses de RNA e proteina. A microscopia eletrōnica revelou algumas características dos efeitos da deficiência de zinco. As células no inĩcio da fase estacionäria mostraram, nitidamente, um aspecto de citoplasma degradado parecendo ser delimitado por uma única membrana e contendo, às vezes, mi tocôndrias parcialmente degradadas e estruturas semelhantes aos vacūolos autofágicos e lisossomos.

WEGENER e ROMANO (1973) determinaram o efeito do zinco sobre o crescimento e produção de RNA, DNA e proteîna por Rhizopus nigricans. A adição do microelemento estimulou imediatamente a síntese de RNA, enquanto que a sintese de proteîna demorou mais a atingir a taxa de sīntese máxima, 
porêm ao atingi-la tanto RNA como proteĩna cresceram na mesma taxa relativa. Os nîveis de DNA aumentaram muito pouco em relação aos de RNA e proteí na. O aumento no crescimento e utilização de glicose foi similar ao da sin tese proteica. O mecanismo pelo qual o zinco estimula a sintese de RNA não é conhecido. Segundo os autores, o aumento em nucleotideos livres, apōs adição do metal pode indicar um papel na sintese de purinas e pirimidinas ou nucleotỉdeos.

VEGA e TOURNEAU (1974) encontraram que a omissão de zinco resultou num decrēscimo no peso seco de Whetzelinia sclerotiorum (Sclerotinia. sclerotiorum) e na ausência de produção de esclerócio em três dos quatro isolados testados. Os autores esclarecem que a formação deste corpo de frutificação em um dos isolados pode ter sido devida a uma baixa exigência por zinco e presença de pequenas quantidades do elemento no meio.

WOLD e SUZUKI (1976) encontraram que a concentraçào de zinco determina o curso da produção de ácido cítrico por Aspergillus niger. Altas concentraçōes do metal mantinham as culturas na fase de crescimento, on de não havia acümulo do ăcido e níveis baixos limitavam o crescimento e o organismo passava à fase de acúmulo do ácido. A adição de zinco às cultu ras acidogênicas resultava na reversão para a fase de crescimento e paralização do acúmulo de ácido. Estes resultados estào de acordo com relatos de outros pesquisadores anteriormente citados.

GUPTA et alii (1977) observaram que o crescimento e produção de aflatoxina por Aspergilius parasiticus foram inibidos pela deficiencia de zinco.

A utilização da raiz de mandioca para o desenvolvimento de mi crorganismos pode ser limitada pela presença de microelementos em níveis 
não adequados.

GRAY a ABOU - EL - SEOUD (1966), usando como fonte de carbono, para o crescimento de do is isolados de Cladosporium, a farinha de mandioca, verificaram que uma maior produção pode ser obtida pela adição de certas ví taminas e minerais ao meio de cultura e que depende do microrganismo usado. A produção a partir do Cladosporium cladosporioides, I-83 quase que dobrou quando foram adicionados tais aditivos. O mesmo não ocorreu com 0 Cladosporium cladosporioides I-75 que teve su produção reduzida de aproximadamen te um terço na presença dos aditivos. Os autores chamam atenção para as diferenças individuais existentes entre os microrganismos e para o fato de que o sucesso do uso de cada material fresco contendo carboidrato depende, em grande parte, da seleção do microrganismo a ser usado. Se um determinado microrganismo cresce bem e sintetiza proteina eficientemente a partir de um substrato fresco não se pode dizer que este mesmo microrganismo terá o mesmo sucesso com outro substrato fresco ou com o mesmo substrato tendo sido processado diferentemente.

BARRIOS E BRESSANI (1967) verificaram que as concentrações de ferro, determinadas, em diversas variedades de mandioca provenientes da zona subtropical seca e tropical seca da Guatmala, a resentaram grandes diferenças mesmo entre as variedades de uma mesma região.

STANTON e WALLBRIDGE (1969), utilizando amido de mandioca como substrato para a produção de proteina por fungos do gênero Rhizopus, observaram que ferro, zinco e manganès podem ser inibitörios ou estimulatórios dependendo da raiz utilizada.

GREGORY, et alii (1977), produzindo proteina füngica a partir 
de mandioca atravēs de um mutante näo esporogênico de Aspergillus fumiga tus, verificaram que o amido de suas rarzes parece suprir quantidades ade. quadas de todos os elementos minerais exigidos pelo microrganismo, exceto enxofre e, possivelmente, zinco. 
4. METODOLOGIA

\subsection{Preparo do Material}

Raỉzes de mandioca da variedade IAC-YARA (7476-67) foram fornecidas pela Estação Experimental de Piracicaba, São Paulo. Foram lavadas, descascadas, passadas em ralador de modo a se obter finas tiras semelhantes a talharins para facilitar a secagem, pesadas, colocadas em bandejas e deixadas em estufa com circulação de ar forçada a 4500 até estabilização do peso, sendo desta maneira, determinado o teor de umidade. 0 tempo decorri do entre a colheita das raizes e seu preparo para desidratação foi cerca de trés horas. As tiras bem secas foram moídas e, em seguida, passadas em pe neira de 150 mesh para el iminação das fibras. O material foi guardado em frascos àmbar hermeticamente fechados. Foi tomada uma amostra para determinações de ferro e zinco, as quais foram realizadas na Secção de Quỉmica A nalEica do Centro de Energia Nuclear na Agricultura, atravës do Espectrofotômetro de Absorção Atômica Perkin-Elmer modelo 306. 
Toda a vidraria utilizada foi l avada com detergente, água des tilada, ácido clorídrico a $20 \%$, ägua desmineralizada, $\left(\mathrm{NH}_{4}\right)_{3}$ EDTA a $10 \%$ com pH 8 (preparado com $100 \mathrm{~g}$ de ācido etileno diamino tetracētico e cerca de $500 \mathrm{ml}$ de água desmineralizada, acertando-se o pH a 8 com hidrōxido de amōnio e ajustando-se o volume final a um litro) e, finalmente, com àgua desmineralizada.

Foram preparadas soluções estoque de ferro e zinco, com ägua desmineralizada, ambas contendo 500 ppm de cada elemento, respectivamente.

4.2. Escolha do Microrganismo e Determinação do pH Otimo

Foram ensaiados 3 fungos (Aspergillus niger IZ-9 e Aspergillus, wentij IZ-1625, cedidos pela Micoteca do Instituto Zimotécnico do Departa mento de Tecnologia Rural da Escola Superior de Agricultura "Luiz de Quei roz", e Fusarium sp., isolado de raiz de mandioca com cerca de 7 dias apōs ter sido colhida e deixada, acidentaimente, ao ar livre) e 8 valores de $\mathrm{pH}$ (de 2 a 9 ) seguindo-se o esquema fatorial.

0 meio foi preparado contendo por litro 30 gramas de amido de mandioca e urēia na quantidade suficiente para fornecer 1,2 gramas. Foi gelatinizado entre $60-700 \mathrm{C}$ durante 15 minutos, resfriado em ägua corrente e distribuifdo em 8 frascos de Erlenmeyer de $500 \mathrm{ml}$ para ajustagem do $\mathrm{pH}$ nos valores de 2 a 9 , a qual foi feita com àcido sulfúrico $2 \mathrm{~N}$ e hidróxido de sódio 2 N. Em seguida, foi distribuỉdo em 72 frascos de $250 \mathrm{ml}$, cada um 
contendo $50 \mathrm{ml}$ de meio, sendo 9 repetições para cada valor de ph e 3 para cada fungo. A esterilização foi feita a $1210 \mathrm{C}$ por 15 minutos.

Os inöculos foram obtidos de culturas de 4 dias de idade desen volvidas em meio de malte agar, em placas de Petri, tomando-se discos de $5 \mathrm{~mm}$ de diâmetro da periferia das colônias.

Tendo sido feita a inoculação, os frascos foram colocados num agitador regulado para 120 batidas por minutos. A temperatura foi mantida entre $28-30 \div$ C.

Apōs 4 dias de incubação mediu-se o pH dos meios e, em segui da, o material foi filtrado para a determinação do peso seco em estufa atē peso constante, na temperatura de $600 \mathrm{C}$ de modo a garantir que houvesse inalteraçäo no perfil de aminoäcidos (SPICER, 1971).

4.3. Ensaio de Duas Fontes de Nitrogēnio UUrēia e Nitrato de Amónio) para o Crescimento de Fusarium sp. Aspergillus niger IZ-9. e Aspergillus wentit 12-1625 em Meio de Amido de Mandioca.

Foram preparados $500 \mathrm{ml}$ de dois meios, ambos contendo 3 gra mas de amido por cento e uréia ou nitrato de amônio, respectivamente, nas quantidades suficientes para fornecerem 0,12 gramas de nitrogênio por cento. Os meios foram gelatinizados e $0 \mathrm{pH}$ ajustado para 3 . Em seguida,fo ram distribuidos em 18 frascos de Erlenmeyer de $250 \mathrm{ml}$, cada um contendo $50 \mathrm{ml}$ de meio, sendo 9 repetições para cada fonte de nitrogênio e 3 para Cada fungo, apōs o que foram esterilizados. Os inóculos foram obtidos de 
maneira similar à descrita anteriormente.

Apōs 4 dias de incubação num agitador regulado para 120 batidas por minuto e numa temperatura de $28-300 \mathrm{C}$, mediu-se o pH final dos meios e o material foi filtrado para a determinação do peso seco.

4.4. Ensaio de Cinco Niveis de Zinco e Cinco de Ferro para o Cresci. mento de Aspergillus niger IZ-9 em Meio de Amido de Mandioca e. Uréta

Foram testados niveis de 0 a 4 de zinco e ferro, corresponden tes às concentrações de $0,45=5,45=10,45-15,45$ e 20,45 ppm e 0,51 $5,51-10,51-15,51$ e 20,51 ppm, respectivamente, de acordo com o esquema fatorial.

Ds meios foram preparados em 25 frascos de Erlenmeyer de 250 $\mathrm{ml}$, contendo 3 gramas por cento de amido de mandioca e uréia na quantidade suficiente para fornecer 0,12 gramas de nitrogēnio por cento. As diferentes doses de ferro e zinco foram adicionadas tamando-se volumes de $0-2$ 4 - 6 e $8 \mathrm{ml}$ tanto da solução de sulfato ferroso como da de sulfato de zinco, as quais continham 500 ppm de ferro e zinco, respectivamente, correspon dentes aos niveis $0-1-2-3$ e 4 de cada elemento, considerando-se que a quantidade de amido utilizada para cada $200 \mathrm{ml}$ de meio possuia 0,45 ppm de zinco e 0,51 ppm de ferro. Apōs as devidas distribuições das soluções de sulfato de zinco nos 25 frascos, seus volumes foram completados a $200 \mathrm{ml}$ 
com ägua desmineralizada, cujo pH foi previamente ajustado para 3,0 com äcido sulfürico $2 \mathrm{~N}$. Em seguida, os meios foram aquecidos a 60-709C por 15 minutos para gelatinização do amido. Cada meio foi distribuído em 5 fras cos de Enlenmeyer de $250 \mathrm{~m}$ previamente marcados para $50 \mathrm{ml}$ que foi a quanWida de meio utilizada. Assim, foram tomadas 3 repetiçōes para cada tra tamento. A esteriłização foi feita a 121 OC por 15 minutos. 0 inóculo foi obtido como jä descrito anteriormente.

A incubação foi realizada num agitador "regulado para 120 bati " das por minutos e numa temperatura de $28-300 \mathrm{C}$. Apōs 4 dias foram determinados os valores do pH final dos meios e o material filtrado para determina ção do peso seco e nitrogênio total, a qual foi realizada na secção de Quỉmica Analpitica do Centro de Energia Nuclear na Agricultura pelo método Kieldanl, atraves do Analisador Automätico II da Technicon, multiplicando se pelo fator 6,25 para transformação em proteina bruta (American Associa tion of Cereal Chemists. Inc., 1962). O perfilo de aminoäcidos das produ çöes obtidas com a melhor combinação encontrada foj determinado na Secção de Broquimica de Plantas do Centro de Energia Nuclear na Agricultura, atrayës do Analisador Automātico de Aminoäcidos Beckman Modelo $120 \mathrm{C}$.

4.5. Ensai de Cinco Niveis de Ferro para o Crescimento de Aspergil Ius niger IZ-9 em Mejo Amido de Mandioca, Uréia e Sulfato de Zinco na Concentração Ótima Encontrada

Foram testados nTueis de 0 a 4 de ferro, correspondentes às con centraçoss de $15,51-20,51-25,51-30,51$ e 35,51 ppm do elemento, man - 
tendo-se o zinco na concentração ötima encontrada no ensaio anterior.

Os meios foram preparados em 5 frascos de Erlenmeyer de $200 \mathrm{ml}$ contendo 3 gramas de carboidrato por cento, uréia na quantidade suficiente para fornecer 0,12 gramas de nitrogênio por cento e sulfato de zinco suficiente para 5 ppm do metal (a quantidade de amido utilizada forneceu 0,45 ppm). As doses de ferro foram adicionadas tomando-se volumes de 6 - 8 10 - 12 e $14 \mathrm{ml}$ da solução de sulfato ferroso contendo 500 ppm do metal,cor respondentes aos niveis $0-1-2-3$ e 4 , considerando que a quantidade de amido utilizada para cada $200 \mathrm{ml}$ de meio possuĩa $0,51 \mathrm{ppm}$ de ferro. Os volumes foram ajustados para $200 \mathrm{ml}$ com ägua desmineralizada, cujo pH foi previamente ajustado para $3,0 \mathrm{com}$ äcido sulfürico $2 \mathrm{~N}$, apōs o que os meios foram gelatinizados e cada um deles distribuido em 3 frascos de $250 \mathrm{ml}$ previamente marcados para $50 \mathrm{ml}$, que foi a quantidade de meio utilizada, correspondentes a três repetições para cada tratamento. Apōs esterilização, os meios foram inoculados, incubados e, apōs 4 dias, tiveram seus valores de $\mathrm{pH}$ determinados e o material foi filtrado para determinação do peso seco, conforme descrito anteriormente.

4.6. Curva de Crescimento do Aspergillus niger IZ-9 em Meio de Amido de Mandioca, Uréia, Sulfato de Zinco e Sulfato Ferroso.

Tendo sido determinados o melhor microrganismo, o pH ótimo e as concentrações de zinco e ferro necessärias para produzir o maior desenvolvi 
vimento do microrganismo, foi feita a sua curva de crescimento dentro das condições ótimas encontradas.

Como nos ensaios anteriores, o meio foi gelatinizado e o pH ajustado para o valor ötimo determinado. Em seguida, foi distribuido em 27 frascos de Erlenmeyer de $250 \mathrm{ml}$, os quais foram autoclavados, inoculados e incubados a $28-30 . \mathrm{C}$ em agitador regulado para 120 batidas por minuto.

As determinações do $\mathrm{pH}$ final, peso seco e proteina bruta foram feitas tomando-se três amostras em intervalos de 12 horas num período de 24 a 144 horas.

\subsection{Determinação de Aflatoxina}

Foi utilizado o método proposto por PONS et alii (1966) para detectar a presença de aflatoxina em micēlio de Aspergillus niger IZ-9 desenvolvido em meio amido de mandioca, urēia, sulfato de zinco e sulfato de ferro.

\subsection{Anāise Estatistica}

Na anälise de variância foi feito o teste $F$ para se verificar a significância da ação dos tratamentos sobre a produção de biomassa e prote na, assim como das interações e suas decomposições. Pela anālise de regressão foram encontradas as equações que melhor se adaptam aos dados obser 
vados em cada caso. Foi determinado o coeficiente de correlação linear en tre a biomassa produzida por Aspergillus niger. IZ-9 em meio de amido de man dioca e urēia, onde foram testados cinco niveis de ferro fixando-se o zinco na concentração ötima encontrada, e o pH final dos meios (GOMES, 1973). A comparação das mëdias foi feita pelo teste de Student-Newman-Keuls (STEEL e TORRIE, 1960). 
43.

\section{RESULTADOS}

5.1. Determinação do Teor de Micronutrientes no Amido de Mandioca.

A anāilse de micronutrientes mostrou que o amido utilizado possula $17 \mathrm{ppm}$ de ferro e $15 \mathrm{ppm}$ de zinco.

5.2. Escolha do Microrganismo e Determinação do pH Otimo.

Apös a esterilização, observoumse que a viscosidade dos meios foi aumentando gradativamente do $\mathrm{pH} 2$ ao 9.

Dentro da faixa de pH testada, o Fusarium sp. nao cresceu em pH 2. Por este motivo, a anālise estatistica foi feita eliminando-se o tratamento com este valor de pH. Os resultados foram tomados em gramas de micelio (peso seco) por litrq de meio (Tabela 1). 
Tabela 1. Produção de Biomassa (Peso Seco em gramas/litro) por Fusarium sp, Aspergillus niger IZ-9 e Aspergillus wentii IZ-1625 em Meio de Raiz de Mandioca e Uréia na Faixa de pH de 2 a 9 e Determinação do pH Final do Meio (Mëdias de três repetições)

\begin{tabular}{|c|c|c|c|c|c|c|}
\hline \multirow{2}{*}{$\begin{array}{l}\mathrm{pH} \\
\text { Inicial }\end{array}$} & \multicolumn{2}{|c|}{ Fusarium sp. } & \multicolumn{2}{|c|}{ A. niger IZ-9 } & \multicolumn{2}{|c|}{ A. wentii IZ-1625 } \\
\hline & $\begin{array}{c}\mathrm{pH} \\
\text { Final }\end{array}$ & $\begin{array}{c}\text { Peso Seco } \\
(\mathrm{g} / 1)\end{array}$ & $\begin{array}{c}\mathrm{pH} \\
\text { Final }\end{array}$ & $\begin{array}{c}\text { Peso Seco } \\
(\mathrm{g} / 1)\end{array}$ & $\begin{array}{c}\mathrm{pH} \\
\text { Final }\end{array}$ & $\begin{array}{c}\text { Peso Seco } \\
(g / 1)\end{array}$ \\
\hline 2 & 3,0 & - & 2,8 & 8,11 & 6,0 & 4,35 \\
\hline 3 & 8,7 & 2,94 & 3,9 & 9,66 & 6,2 & 8,28 \\
\hline 4 & 8,4 & 2,39 & 3,8 & 9,33 & 6,5 & 6,19 \\
\hline 5 & 8,3 & 3,02 & 3,5 & 7,08 & 6,3 & 6,24 \\
\hline 6 & 8,4 & 2,12 & 3,8 & 3,69 & 7,3 & 4,92 \\
\hline 7 & 8,3 & 3,01 & 6,1 & 1,26 & 6,6 & 6,89 \\
\hline 8 & 8,5 & 3,36 & 5,9 & 1,65 & 6,1 & 7,63 \\
\hline 9 & 8,4 & 3,38 & 6,5 & 1,49 & 6,7 & 7,74 \\
\hline
\end{tabular}

A anālise de variância (Tabela 2), revelou haver diferença altamente significativa a nivel de $3 \%$ de probabilidade, pelo menos, entre duas produções obtidas devido aos microrganismos e aos valores de pH. A interação fungos X pH mostrou-se altamente significativa a nỉvel de $1 \%$ de probabilidade, indicando que pelo menos um dos microrganismos se comporta de maneira distinta nos diferentes valores de pH testados. 
Tabela 2. Anālise de Variância Referente à Produção de Biomassa (Peso Seco en gramas/litro) por Fusarium $5 p$. Aspergillus niger IZ-9 e Aspergillus wentif IZ-1625 na Faixa de pH de 3 a 9

\begin{tabular}{lcccc}
\hline Causa de Variação & G.L. & S.Q. & Q.M. & F. \\
\hline Fung*s & 2 & 163,99 & 81,99 & $154,71 * *$ \\
$\mathrm{pH}$ & 6 & 88,05 & 14,68 & $27,69 * *$ \\
Int. Fungos $\times \mathrm{pH}$ & 12 & 197,89 & 15,99 & $30,17 * *$ \\
\hline (Tratamentos) & $(20)$ & $(443,93)$ & $(22,20)$ & $(41,88 * *)$ \\
Resîduo & 42 & 22,14 & 0,53 & \\
\hline Total & 62 & 466,07 & & \\
\hline
\end{tabular}

** - Significativo $p \leq 0,01$

C.V. $=10,88 \%$

Pelo desdobramento da interação (Tabela 3), pode-se observar que apenas o fusarium sp. não apresentou variações significativas, indicando que a baixa produção observada independe do pH inicial. Tanto o Aspergillus niger IZ-9 como o Aspergillus wentii IZ-1625 apresentaram variações a) tamente significativas a nível de $1 \%$ de probabilidade, sendo o primeiro mais sensĩvel à variação de $\mathrm{pH}$ inicial.

A comparação da melhor média obtida com as demais pelo teste de Student - Newman - Keuls (Tabela 4) revelou que a mëdia da maior produ ção, obtida pelo A. niger IZ-9 em pH 3, não diferiu significativamente apenas aquela dada pelo mesmo fungo em pH 4 e pelo A. wentij 1Z-1625 em pH 3. 
Tabela 3. Desdobramento da Interação Fungos $\times$ pH Referente à Produção de Biomassa (Peso Seco em gramas/litro) por Fusarium sp., A. niger 12-9 e A. wentil IZ-1625 na Faixa de pH de 3 a 9.

\begin{tabular}{lcrrr} 
Causa de Variação & G.L. & S.Q. & $0 . M$ & F \\
\hline $\mathrm{pH} /$ Fusarium & 6 & 4,02 & 0,67 & 1,26 NS \\
$\mathrm{pH} /$ A. niger & 6 & 252,02 & 42,00 & $79,25 *$ * \\
$\mathrm{pH} /$ A. wentil & 6 & 23,97 & 3,98 & $7,52 * *$ \\
Residuo & 42 & 22,14 & 0,53 &
\end{tabular}

NS - Não significativo

** - Significativo $p \leq 0,01$

Diferiu significativamente a nivel de $5 \%$ de probabilidade da média produzida pelo A. niger. IZ-9 en pH 9 e a nivel de $1 \%$ de probabilidade, en rela ção a todas as demais.

Tendo sido estabelecida a superioridade do A. niger IZ-9 e do A. wentii IZ-1625 sobre o fusarium sp., em relação à produção de biomassa, este fungo foi descartado e nova anälise estatistica foi feita considerando-se apenas os dois primeiros fungos e incluindo-se $0 \mathrm{pH} 2$.

A anälise de variancia (Tabela 5) revelou diferença altamente significativa a nivel de $1 \%$ de probabilidade entre pelo menos dois dos valores de pH utilizados. A produção total do Aspergillus niger IZ-9 diferiu a nivel de $1 \%$ de probabilidade daquela obtida elo Asperginus wentil IZ1625. sendo o ult timo o melhor em produção de biomassa. A interação pH $x$ fungos revelou-se altamente significativa a nivel de $1 \%$ de probabilidade, 
Tabe 1a 4. Teste de Student-Newman-Keuls para Comparação das Médias de Produção de Biomassa (Peso Seco em gramas/1itro) Dadas por Fusarium $\mathrm{sp}$, Aspergillus niaer IZ-9 e Aspergillus wentii IZ-1625 na Faixa de $\mathrm{pH}$ de 3 à 9.

\begin{tabular}{|c|c|c|c|}
\hline Fungo & $\mathrm{pH}$ & $\begin{array}{l}\text { Médias de } \\
\text { Peso Seco } \\
(g / 1)\end{array}$ & $\begin{array}{l}\text { Valores do Teste de Stu- } \\
\text { dent - Newman-Kuels Para } \\
\text { a Mëdia } 9,66\end{array}$ \\
\hline A. niger $I Z-9$ & 7 & 1,26 & $20,00 * *$ \\
\hline A. niger IZ-9 & 9 & 1,49 & $19,45 * *$ \\
\hline A. niger $I Z-9$ & 8 & 1,65 & $19,07 * \star$ \\
\hline Fusarium sp. & 6 & 2,12 & $17,95 * *$ \\
\hline Fusarium sp. & 4 & 2,39 & 17,31 ** \\
\hline Fusarium sp. & 3 & 2,94 & $16,00 * \star$ \\
\hline Fusarium sp. & 7 & 3,01 & $15,83 * *$ \\
\hline Fusarium sp. & 5 & 3,02 & $15,81 * *$ \\
\hline Fusarium sp. & 8 & 3,36 & $15,00 * *$ \\
\hline Fusarium $s p$. & 9 & 3,38 & $14,95 * *$ \\
\hline A. niger IZ-9 & 6 & 3,69 & $14,21 * *$ \\
\hline A. wentif IZ-1625 & 6 & 4,92 & 11,29 ** \\
\hline A. wentii $1 Z-1625$ & 4 & 6,19 & $8,26 * \star$ \\
\hline A. wentil $12-1625$ & 5 & 6,24 & $8,14 * *$ \\
\hline A. wentil IZ-1625 & 7 & 6,89 & $6,60 * *$ \\
\hline A. niger IZ-9 & 5 & 7,08 & $6,14 * *$ \\
\hline A. wentil IZ- 1625 & 8 & 7,63 & $4,83 * *$ \\
\hline A. wentil $1 Z-1625$ & 9 & 7,74 & 4,57 * \\
\hline A. wentii $12-1625$ & 3 & 8,28 & 3,29 NS \\
\hline A. niger IZoog & 4 & 9,33 & 0,79 NS \\
\hline A. niger IZ-9 & 3 & 9,66 & - \\
\hline
\end{tabular}

NS - Näo significativ

* - Significativo $p \leq 0,05$

** - Significativo $p \leq 0,01$ 
indicando que a variação obtida na produção não ocorreu devido a ação isolada dos dois fatores e que o comportamento de cada fungo é distinto nos diferentes valores de $\mathrm{pH}$.

Tabela 5. Anālise de Variāncia Referente à Produção de Biomassa (Peso Seco em gramas/litro) por A. niger IZ-9 e A. wentii IZ-1625 na Faixa de $\mathrm{pH}$ de 2 a 9.

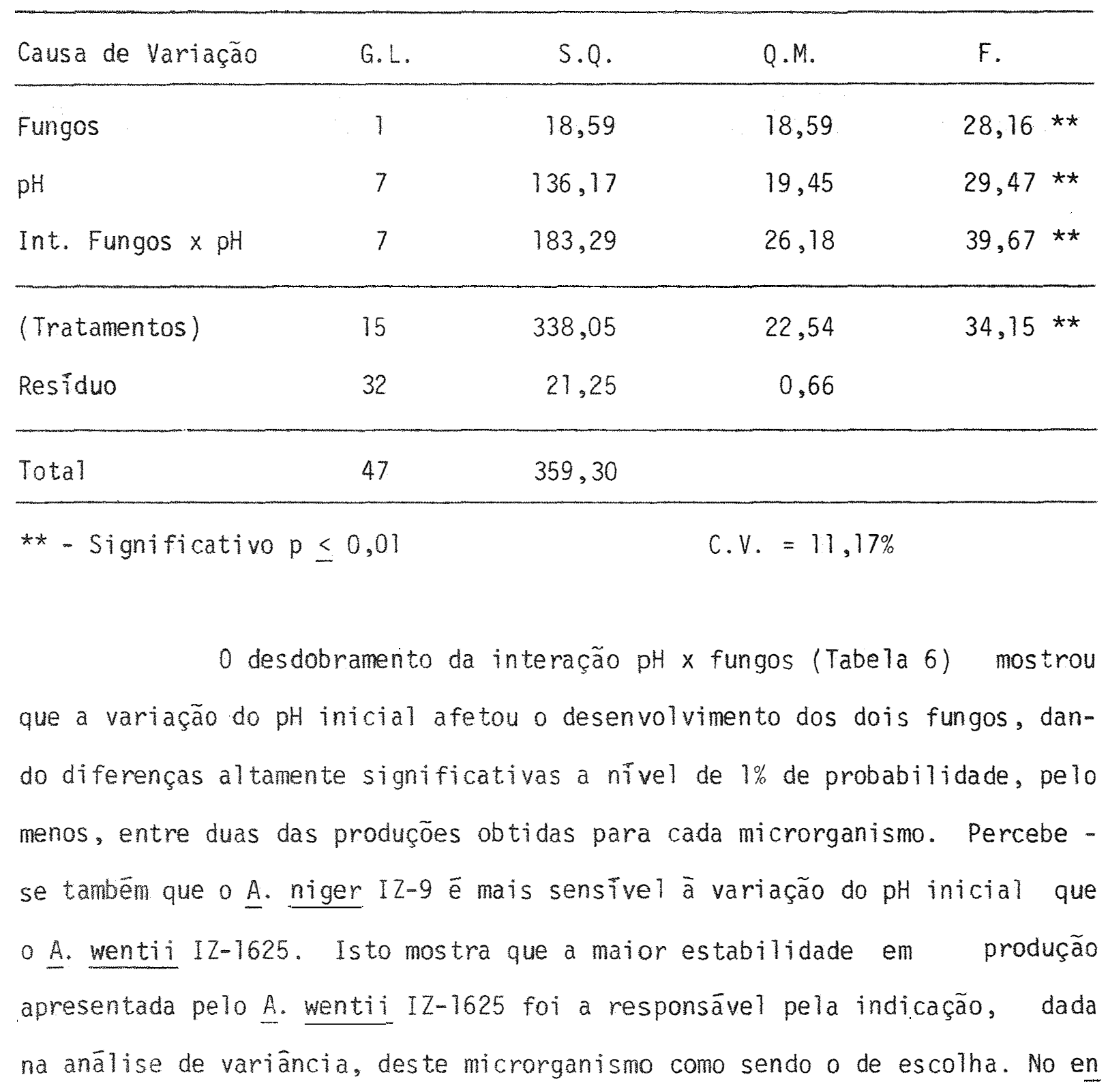


tanto, numa determinada faixa de pH desejada o Aspergillus niger IZ-9 se comportou, em termos de produção de biomassa, tão bem quanto o $\underline{A}$. wentii IZ 1625 e, quanto à estabilidade, melhor do que o mesmo, como mostra a comparação das mëdias pelo teste de Student - Newman - Keuls (Tabela 7). Esta comparação revelou que entre a melhor média obtida produzida pelo A. niger IZ-9 em pH 3 e aquelas dadas pelo mesmo fungo em pH 2 e 4 e pelo A. wentij IZ-1625 em pH 3 e 9 não houve diferença significativa, porëm entre a melhor média e as produzidas pelo A. wentii IZ-1625 em pH 2 e 4 e todas as outras mëdias foram encontradas diferenças altamente significativas a nivel de $1 \%$ de probabilidade. Deste modo, foi selecionado o $\underline{A}$. niger IZ-9 para o presente trabaiho. Em relação à maior produção do A. wentii IZ-1625 foram encontradas diferenças altamente significativas a nivel de $7 \%$ de probabilidade quando comparada com 0 A. niger IZ-9 em pH 6, 7,8 e 9 e 0 A. wentif IZ1625 em pH 2 e 6 e nenhuma diferença com as demais produções.

Tabela 6. Desdobramento da Interação Fungos $\times$ pH Referente à Produção de Biomassa (Peso Seco em gramas/litro) por A. niger IZ-9 e $\underline{A}$. wentii IZ-1625 na Faixa de pH de 2 a 9.

\begin{tabular}{lcrrr} 
Causa de Variação & G.L. & S.Q. & Q.M. & \multicolumn{1}{c}{. } \\
\hline pH / A. niger & 7 & 279,32 & 39,90 & $60,46 * *$ \\
pH $/$ A. wentii & 7 & 40,15 & 5,74 & $8,69 * *$ \\
Residuo & 32 & 21,25 & 0,66 &
\end{tabular}

$* *$ - Significativo $p \leq 0,01$ 
50.

0 pH final do meio foi determinado (Tabela 1). A partir do pH inicial 3, as culturas do Fusarium sp. mostraram elevação do pH para valores em torno de 8,3. Em pH 2, onde não se observou crescimento, o pH final foi 3. Para O A. niger IZ-9 houve elevação do pH nos valores iniciais 2 e 3 e redução nos demais. Finalmente, para 0 A. wentii $12-1625$ as culturas tiveram o pH elevado em valores iniciais de 2 a 6 e reduzido nos demais.

Tabela 7. Teste de Student-Newman-Keuls para Comparação das Médias de Produção de Biomassa (Peso Seco em gramas/litro) Dadas por A. niger IZ-9 e A. wentii IZ-1625 na Faixa de pH de 2 a 9.

\begin{tabular}{|c|c|c|c|c|c|c|c|}
\hline Fungo & & $\mathrm{pH}$ & $\begin{array}{l}\text { Médias de } \\
\text { Peso Seco } \\
(g / 1)\end{array}$ & $\begin{array}{l}\text { Valores } \\
\text { Teste Par } \\
\text { a Média } 9\end{array}$ & $\begin{array}{l}\text { do } \\
r a \\
.66\end{array}$ & $\begin{array}{l}\text { Valores do } \\
\text { Teste Para } \\
\text { a Média } 8,28\end{array}$ & $\begin{array}{l}\text { Valores do } \\
\text { Teste Para } \\
\text { a Média } 3,69\end{array}$ \\
\hline A. niger & $I Z-9$ & 7 & 1,26 & 17,87 & $\star \star$ & $14,94 * *$ & $5,17 * *$ \\
\hline A. niger & $I Z-9$ & 9 & 1,49 & $17,38=$ & $\star \star$ & $14,45 * *$ & $4,68 * *$ \\
\hline A. niger & $I Z-9$ & 8 & 1,65 & 17,04 & $* *$ & $14,11 * *$ & $4,34 * \star$ \\
\hline A. niger & $12-9$ & 6 & 3,69 & 12,70 & $\star \star$ & $9,77 * \star$ & - \\
\hline A. wentii & $1 Z-1625$ & 2 & 4,35 & 11,30 & $\star \star$ & $8,36 * *$ & \\
\hline A. wentil & $1 Z-1625$ & 6 & 4,92 & 10,09 & $* *$ & $7,15 * *$ & \\
\hline A. wentil & $1 Z-1625$ & 4 & 6,19 & 7,38 & $* *$ & 4,45 NS & \\
\hline A. wentio & $1 Z-1625$ & 5 & 6,24 & 7,28 & $\star *$ & $4,34 \mathrm{NS}$ & \\
\hline A. wentit & $1 Z-1625$ & 7 & 6,89 & 5,89 & $\star \star *$ & 2,96 NS & \\
\hline A. niger & $1 Z-9$ & 5 & 7,08 & 5,49 & $\star *$ & 2,55 NS & \\
\hline A. wentio & $1 z-1625$ & 8 & 7,63 & 4,32 & * & $1,38 \mathrm{NS}$ & \\
\hline A. wentil & $I Z-1625$ & 9 & 7,74 & 4,09 & NS & 1,15 NS & \\
\hline A. niger & $I Z-9$ & 2 & 8,11 & 3,30 & NS & $0,36 \mathrm{NS}$ & \\
\hline A. wentil & $1 Z-1625$ & 3 & 8,28 & 2,94 & NS & - & \\
\hline A. niger & $12-9$ & 4 & 9,33 & 0,70 & NS & & \\
\hline A. niger & $I Z-9$ & 3 & 9,66 & - & & & \\
\hline
\end{tabular}

NS - Não significativo

** - Significativo $p \leq 0,01$ 
5.3. Ensaio de Duas Fontes de Nitrogénio (Uréia e Nitrato de Amōnio) para o Crescimento de Fusarium sp., Aspergillus niger IZ-9 e Aspergillus wentii IZ-1625 em Meio de Amido de Mandioca.

Os resultados da produção de biomassa pelos trēs microrganis mos, tomada em peso seco expresso em gramas/litro, assim como os valores do pH final dos meios estão apresentados na tabela 8. Fusarium sp. não mostrou nenhum crescimento quando nitrato de amónio foi utilizado como fon te de nitrogênio, enquanto que em uréia produziu crescimento, embora incipiente, quando comparado com os demais fungos em ambas as fontes de nitrogê nio. Não tendo o Fusarium sp. apresentado crescimento em nitrato de amô nio foi feita a anāilise estatística levando em consideração apenas os re sultados produzidos pelo Aspergillus niger IZ-9 e pelo Aspergillus wentii IZ-1625.

Tabela 8. Produção de Biomassa (Peso Seco em gramas/litro) por Fusarium sp., Aspergillus niger IZ-9 e Aspergillus wentii IZ-1625 em Meio de Amido de Mandioca Onde Foram Testadas duas Fontes de $\mathrm{Ni}$ trogênio (Urëia e Nitrato de Amónia) e Valores do pH Final dos Meios (Médias de Três Repetições).

\begin{tabular}{lcccc}
\hline Fungøs & Urēia & $\begin{array}{l}\mathrm{pH} \\
\text { Final }\end{array}$ & $\begin{array}{c}\text { Nitrato de } \\
\text { Amönio }\end{array}$ & $\begin{array}{l}\mathrm{pH} \\
\text { Final }\end{array}$ \\
\hline Fusarium sp. & 2,10 & 8,4 & - & 3,5 \\
A. niger IZ-9 & 11,59 & 4,0 & 9,63 & 3,0 \\
A. wentii IZ-1625 & 9,00 & 5,8 & 6,67 & 2,3 \\
\hline
\end{tabular}

A anālise de variāncia (Tabela 9) revelou que os dois micror ganismos se comportaram diferentemente, o mesmo ocorrendo com as fontes de 
nitrogênio, tendo $0 \underline{A}$ niger $I Z-9$ mostrado melhores resultados que 0 . wentii IZ-1625 e a uréia sido superior ao nitrato de amōnio. Não houve in teração significativa entre fungos e fontes de nitrogênio, o que indica que 0 A. niger IZ-9 foi melhor que O A. wentii IZ-1625 independentemente da fon te de nitrogênio e, da mesma forma, a urêia foi melhor que o nitrato de amōnia independentemente dos fungos. Esses resultados foram confirmados comparando-se as mëdias pelo teste de Student-Newman-Keuls (Tabela 10), onde ficou demonstrado que a melhor média, produzida pelo A. niger IZ-9 quando a uréia foi utilizada como fonte de nitrogênio, diferiu significati vamente a nivel de $1 \%$ de probabilidade das demais e a produção obtida pelo A wentii 12-1625 em uréia diferiu, tambëm a nivel de 1\% de probabilidade, da obtida pelo microrganismo em nitrato de amónio.

Tabela 9. Anāi ise de Variāncia Referente à Produção de Biomassa por Aspergillus niger IZ-9 e Aspergillus wentii 12-1625 Apresentada na Tabela 8.

\begin{tabular}{lcccc}
\hline Causa de Variação & G.L. & S.Q. & Q.M. & F. \\
\hline Fungos & 1 & 23,10 & 23,10 & $84,38 * \star$ \\
Fontes de Nitrogēnio & 1 & 13,80 & 13,80 & $50,41 * \star$ \\
Interação Fungos x Fontes & 1 & 0,10 & 0,10 & 0,37 NS \\
\hline (Tratamentos) & $(3)$ & $(37,00)$ & $(12,33)$ & $(45,05 * \star)$ \\
Resĩduo & 8 & 2,19 & 0,27 & \\
\hline Total & 11 & 39,19 & & \\
\hline
\end{tabular}

NS - Não Significativo C.V. $=5,67 \%$ ** - Significativo $p<0,01$ 
Quanto ao $\mathrm{pH}$ final dos meios (Tabela 8) verificou-se que, em relação ao pH inicial, menores alterações ocorreram quando nitrato de amōnio foi utilizado.

Tabela 10. Teste de Student-Newman-Keuls para Comparação das Médias de Produção de Biomassa (Peso Seco em gramas/litro) por Aspergillus niger IZ-9 e Aspergillus wentii IZ-1625 em Meio de Amido de Mandioca Onde Foram Testadas duas Fontes de Nitrogênio (Urê ia e Nitrato de Amōnio).

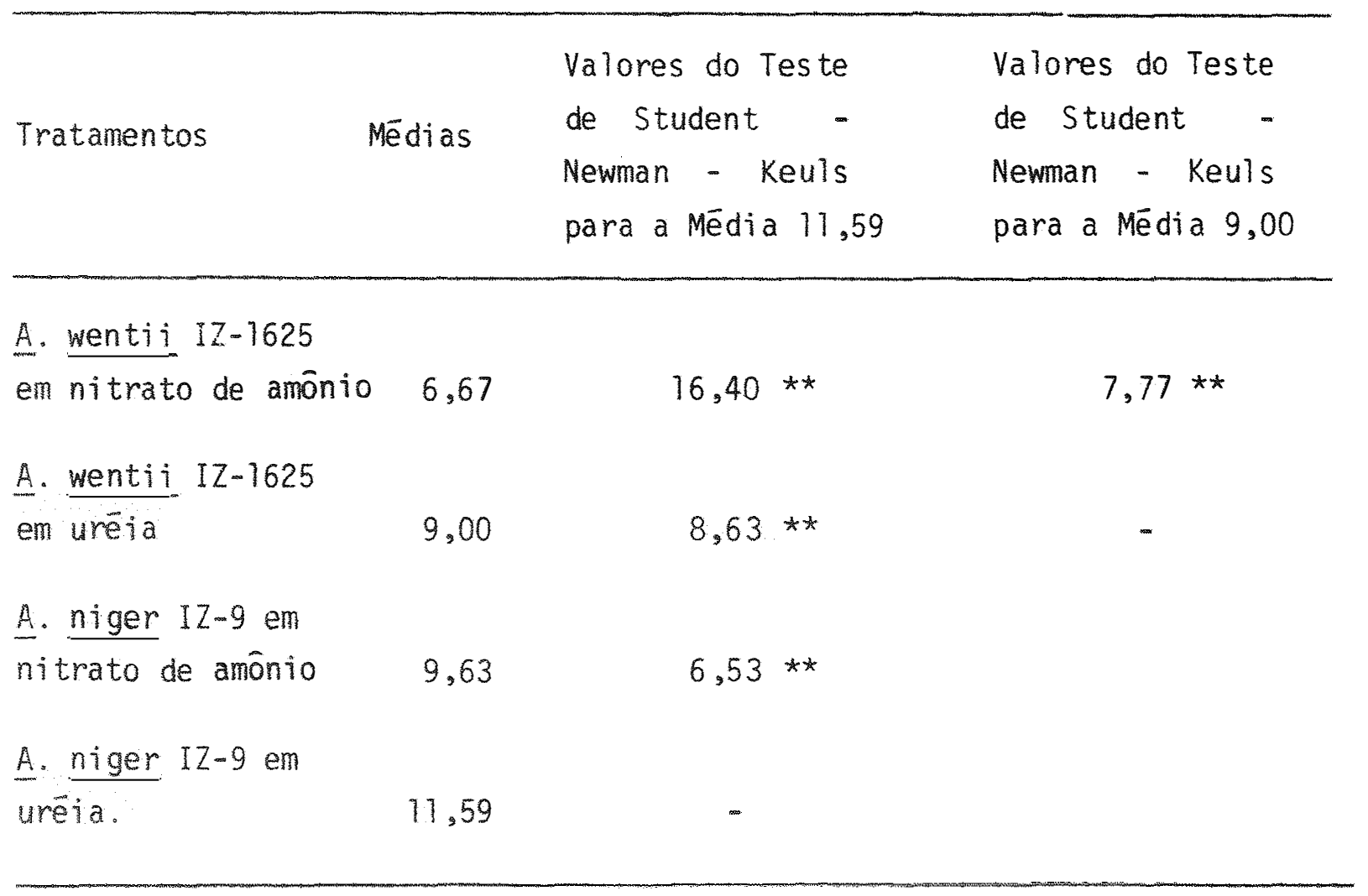

** - Significativo $p \leq 0,01$ 
5.4. Ensaio de Cinco Niveis de Zinco $(0,45-5,45-10,45-15,45$ e $20,45 \mathrm{ppm})$ e Cinco de Ferro $(0,51-5,57-10,51-15,51$ e $20,51 \mathrm{ppm})$ para o Crescimento de Aspergillus niger IZ-9 em Meio de Amido de Mandioca $\quad 3,0$ gramas de Carboidrato por Cento) e Uréia $(0,12$ gramas de Nitrogênio por (ento).

Os resultados deste ensaio foram avaliados em relação à produção de biomassa, tomada em peso seco expresso em gramas/litro (Tabela 11), e à produção de proteina bruta (Tabela 12).

Tabela 11. Produção de Biomassa (Peso Seco em gramas/litro) por Aspergillus niger IZ-9 em Meio de Amido de Mandioca e Uréia Onde Foram Testados Cinco Níveis de Zinco e Cinco de Ferro (Mëdias de très repetições).

\begin{tabular}{lccccc}
\hline & $Z n_{0}$ & $Z n_{1}$ & $Z n_{2}$ & $Z n_{3}$ & $Z_{4}$ \\
\hline $\mathrm{Fe}_{0}$ & 10,26 & 12,01 & 9,29 & 9,86 & 7,47 \\
$\mathrm{Fe}_{1}$ & 10,44 & 13,49 & 9,66 & 8,06 & 1,47 \\
$\mathrm{Fe}_{2}$ & 11,50 & 13,19 & 12,26 & 9,89 & 1,66 \\
$\mathrm{Fe}_{3}$ & 12,44 & 13,82 & 11,70 & 11,18 & 6,73 \\
$\mathrm{Fe}_{4}$ & 13,22 & 14,10 & 11,76 & 12,64 & 7,42 \\
\hline
\end{tabular}

$Z n_{0} \ldots Z n_{4}$ - Niveis de Zinco $(0,45-5,45-10,45-15,45-20,45$ ppm)

$\mathrm{Fe}_{0} \ldots-\mathrm{Fe}_{4}$ - Niveis de Ferro $(0,51-5,51-10,51-15,51-20,51 \mathrm{ppm})$ 
Tabela 12. Produção de Proteina Bruta (gramas/litros) por Aspergillus niger IZ-9 em Meio de Amido de Mandioca e Urëia Onde Foram Testados Cinco Níveis de Zinco e Cinco de Ferro (Média de três repetições).

\begin{tabular}{lllllc}
\hline & $\mathrm{Zn}_{0}$ & $\mathrm{Zn}$ & $\mathrm{Zn}_{2}$ & $\mathrm{Zn}_{3}$ & $\mathrm{Zn}_{4}$ \\
\hline $\mathrm{Fe}_{0}$ & 2,21 & 2,27 & 1,69 & 2,00 & 1,52 \\
$\mathrm{Fe}_{1}$ & 2,25 & 2,90 & 1,88 & 1,68 & - \\
$\mathrm{Fe}_{2}$ & 2,23 & 2,78 & 2,50 & 2,06 & - \\
$\mathrm{Fe}_{3}$ & 2,41 & 2,94 & 2,35 & 2,19 & 1,41 \\
$\mathrm{Fe}_{4}$ & 2,58 & 2,98 & 2,47 & 2,67 & 1,50 \\
\hline
\end{tabular}

$Z n_{0}-\ldots-Z n_{4}$ - Niveis de Zinco $(0,45-5,45-10,45-15,45-20,45 \mathrm{ppm})$

$\mathrm{Fe}_{0}$-.- $\mathrm{Fe}_{4}$ - Niveis de Ferro $(0,51-5,51-10,51-15,51-20,51 \mathrm{ppm})$

Em relação à produção de biomassa a anālise de variāncia (Ta bela 13) revelou que o fungo reagiu tanto aos diferentes niveis de ferro como de zinco, tendo havido um efeito interativo entre os dois elementos, indicando que as variações ocorridas resultaram de uma ação conjunta dos mes mos. 
Tabela 13. Anālise de Variāncia Referente à Produção de Biomassa (Peso Seco em gramas/1itro) por Aspergillus niger IZ-9 em Meio de Amido de Mandioca e Urëia Onde Foram Testados Cinco Níveis de Zinco e Cinco de Ferro.

\begin{tabular}{lcccc}
\hline Causa de Variação & G.L. & S.Q. & Q.M. & F. \\
Ferro & 4 & 99,44 & 24,86 & $37,87 \star \star$ \\
Zinco & 4 & 579,04 & 144,76 & $185,59 \star \star$ \\
Interação Fe $\times$ Zn & 16 & 179,28 & 7,46 & $9,56 \star \star$ \\
\hline Tratamentos) & $(24)$ & $(797,76)$ & $(33,24)$ & $(42,62 \star *)$ \\
Resíduo & 50 & 38,97 & 0,78 & \\
\hline Total & 74 & 836,73 & & \\
\hline
\end{tabular}
** - Significativo $p \leq 0,01$
C.V. $=8,63 \%$

A decomposição da interação ferro x zinco (Tabela 14) mostrou não haver diferença significativa apenas quando o nível 1 de zinco foi estu dado em relação aos diferentes nivieis de ferro, porëm seu valor de $F$ se aproximou muito do tabelado, razão pela qual foi feita anālise de regressão, tendo-se encontrado diferença significativa em relação ao componente de primeiro grau. 
Tabela 14. Decomposição da Interação Ferro x Zinco Relativa à Anālise de Variāncia Apresentada na Tabela 13.

\begin{tabular}{|c|c|c|c|c|c|}
\hline Causa de Variação & G.L. & $S . Q$. & Q.M. & $F$. & \\
\hline $\mathrm{Fe} \times \mathrm{Zn}$ & 16 & 119,28 & 7,46 & 9,56 & $\star \star$ \\
\hline $\mathrm{Fe} / \mathrm{Zn}_{0}$ & 4 & 19,42 & 4,86 & 6,23 & ** \\
\hline $\mathrm{Fe} / \mathrm{Zn}_{1}$ & 4 & 7,85 & 1,96 & 2,571 & NS \\
\hline $\mathrm{Fe} / 2 \mathrm{n}_{2}$ & 4 & 23,17 & 5,79 & 7,42 & $\star \star \star$ \\
\hline $\mathrm{Fe} / 2 \mathrm{n}_{3}$ & 4 & 34,83 & 8,71 & 17,17 & $* *$ \\
\hline $\mathrm{Fe} / \mathrm{Zn}_{4}$ & 4 & 115,44 & 28,86 & 37,00 & $* \star$ \\
\hline $\mathrm{Zn} / \mathrm{Fe}_{0}$ & 4 & 32,34 & 8,08 & 10,36 & ** \\
\hline $\mathrm{Zn} / \mathrm{Fe}_{1}$ & 4 & 238,60 & 59,65 & 76,47 & $* *$ \\
\hline $\mathrm{Zn} / \mathrm{Fe}_{2}$ & 4 & 259,76 & 64,94 & 83,26 & $\star \star$ \\
\hline $\mathrm{Zn} / \mathrm{Fe}_{3}$ & 4 & 86,01 & 27,50 & 27,56 & ** \\
\hline $\mathrm{Zn} / \mathrm{Fe}_{4}$ & 4 & 81,62 & 20,40 & 26,15 & ** \\
\hline Resíduo & 50 & 38,97 & 0,78 & & \\
\hline
\end{tabular}

NS - Não Significativo

$* *$ - Significativo $p \leq 0,01$

As equações de regressão que melhor estimam a produção de bio massa pelo microrganismo estão apresentadas na tabela 15 e as respectivas curvas nas figuras 1 e 2. Pela figura 2 verificou-se que, de um modo geral, a produção de biomassa foi esperada ser máxima num nỉvel intermediärio entre 0 e 1 , ou seja, entre as doses 0,45 e 5,45 ppm do elemento. 
Tabela 15. Equações de Regressão que Melhor Estimam a Produção de Biomassa por Aspergillus niger IZ-9 Relativas às Decomposições da Interação Ferro x Zinco Apresentadas na Tabela 14.

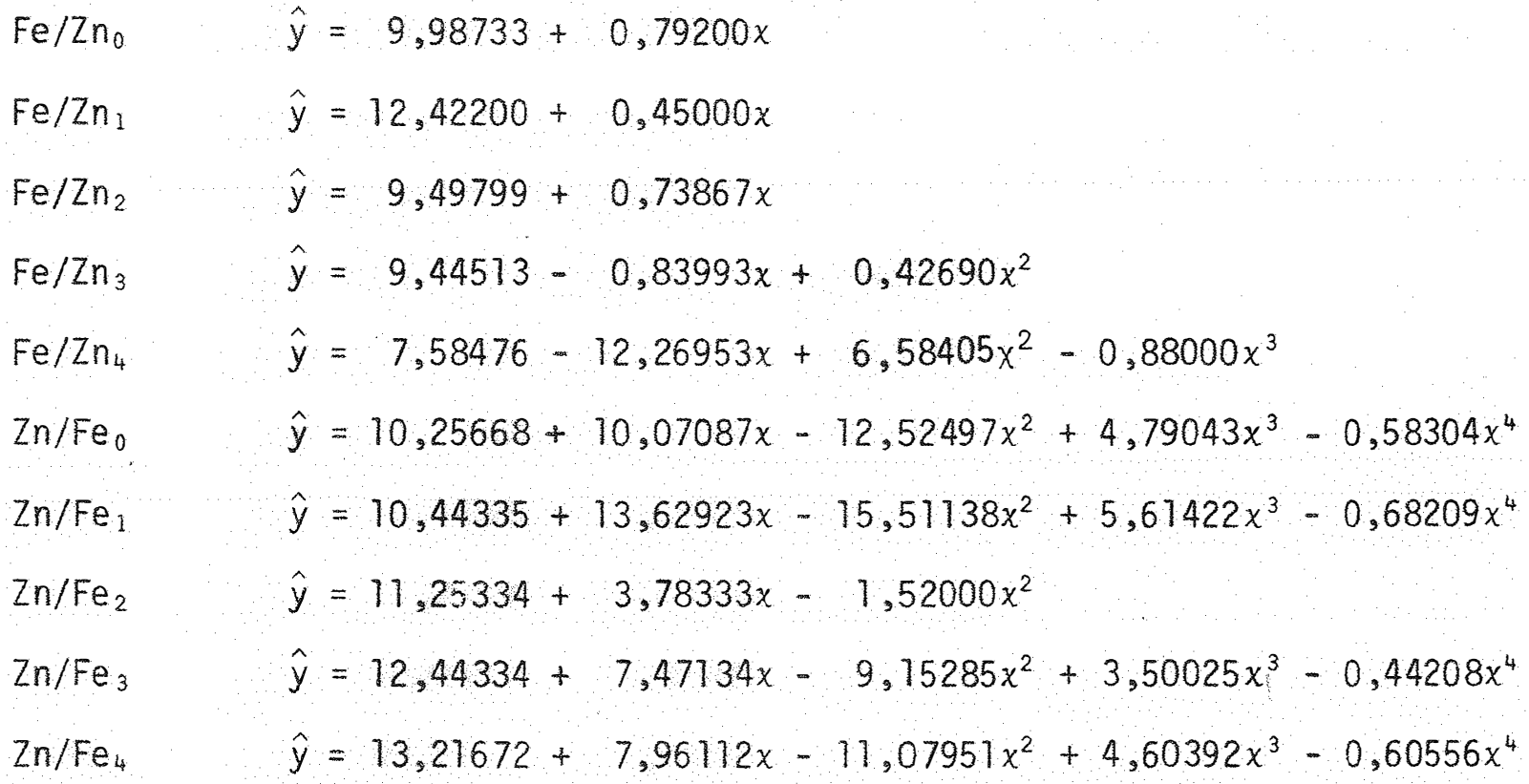

$Z n_{0}-\cdots-Z n_{4}$ - Niveis de Zinco $(0,45-5,45-10,45-15,45-20,45 \mathrm{ppm})$

$\mathrm{Fe}_{0} \ldots \mathrm{Zn} n_{4}$ - Niveis de Ferro $\left.(0,5]-5,51-10,51-15,51-20,51 \mathrm{ppm}\right)$ 
Figura 1. Produção de Biomassa por Aspergillus niger IZ-9 nos Niveis $0(-)$, $1(\ldots),. 2(-\cdots), 3(-\ldots)$ e $4(-x-x-)$ de Zinco, Respectivamente, 0,45-5,45-10,45-15,45 e 20,45 ppm, em Função dos Níveis 0-1-2-3 e 4 de Ferro, Respectivamente, $0,51-5,51-10,51-15,51$ e $20,51 \mathrm{ppm}$.

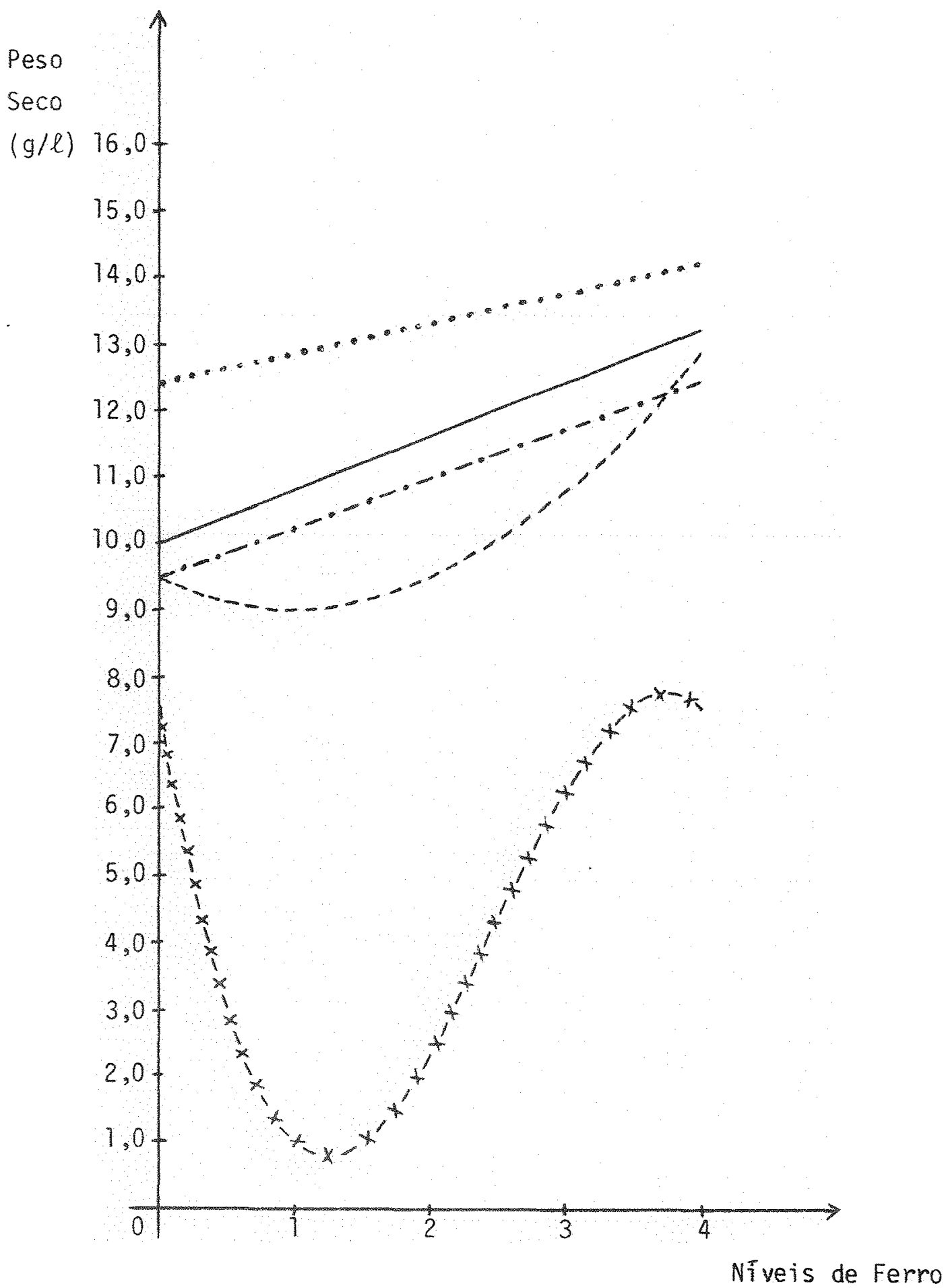


Figura 2. Produção de Biomassa por Aspergilllus niger IZ-9 nos Niveis $0(-)$, $1(\ldots), 2(-\cdots), 3(\cdots)$ e $4(-x-x-)$ de Ferro, Respectivamente, $0,51-5,51-10,51-15,51$ e 20,51 ppm, em Função dos Níveis $0-1-2-3$ e 4 de Zinco, Respectivamente, $0,45-5,45-10,45-15,45$ e $20,45 \mathrm{ppm}$.

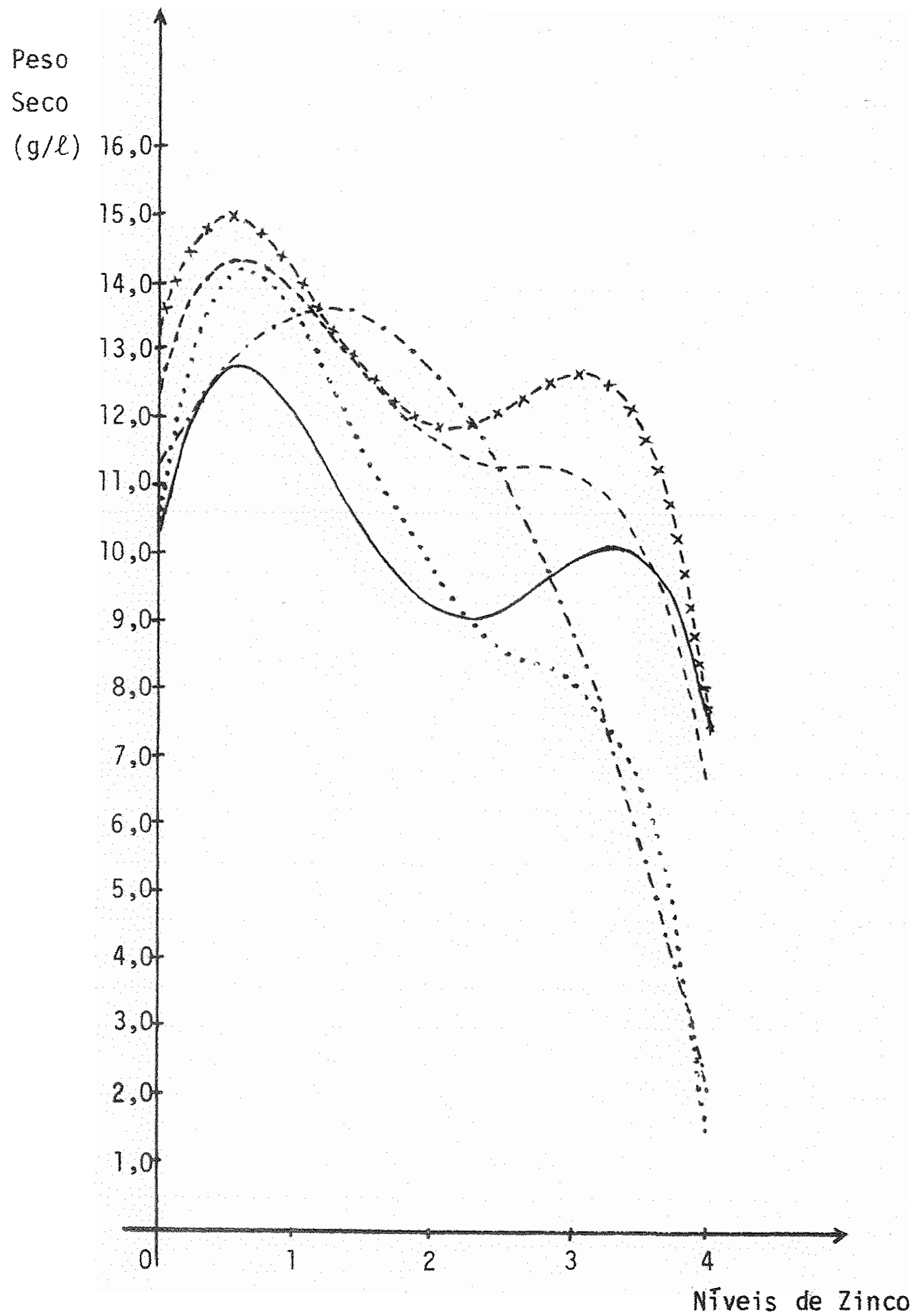


Atravēs da comparação das médias pelo teste de Student Newman - Keuls (Tabela 16) verificou-se que a maior média, produzida na com binação dos nĩveis 4 de ferro e 1 de zinco, não diferiu significativamente das obtidas nas combinações dos nîveis 1 de zinco com qualquer outro de fer ro, zero de zinco com 3 e 4 de ferro, 2 de zinco com 2,3 e 4 de ferro e 3 de zinco com 4 de ferro. Todas as produções de biomassa obtidas com as demais combinações diferiram da maior média, sendo que nas combinações do nível 3 de ferro com 3 de zinco e 2 de ferro com zero de zinco as diferenças foram significativas apenas a nivel de 5\%, enquanto que as demais diferiram a nīvel de $1 \%$ de probabilidade.

Em relação ã produção de proteîna bruta foi eliminado o nível 4 de zinco da anālise estatística porque nas combinações com os níveis 1 e 2 de ferro a produção de biomassa não foi suficiente para as anālise de proteina (Tabela 12).

A anālise de variāncia (Tabela 17) apresentou resultados similares aos obtidos para produção de biomassa. Assim, o fungo reagiu tanto aos nivveis de ferro, como de zinco, os quais também mostraram efeito intera tivo, indicando que não agiram independentemente.

A decomposição da interação ferro x zinco (Tabela 18) mostrou diferença significativa quando os nĩveis de ferro foram estudados em relação a todos os de zinco, com exceção do nĩvel zero e quando os níveis de zinco foram relacionados com todos os de ferro.

As equações de regressão que melhor estimam a produção de pro teîna bruta pelo microrganismo estão apresentadas na tabela 19 e as respectivas curvas nas figuras 3 e 4 . Pela figura 4 a melhor produção de prote $\mathfrak{I}$ na bruta esperada ficou num nỉvel intermediārio entre 0 e 1 de zinco. 
Tabela 16. Teste de Student - Newman - Keuls para Comparação das Médias de Produção de Biomassa (Peso Seco em gramas/litro) por Asper gillus niger IZ-9 em Meio de Amido de Mandioca e Uréia Onde Foram Testados Cinco Niveis de Zinco e Cinco de Ferro.

\begin{tabular}{|c|c|c|}
\hline Tratamentos & Mëdias & $\begin{array}{l}\text { Valores do Teste de } \\
\text { Student - Newman - Keuls } \\
\text { para a Média } 14,10\end{array}$ \\
\hline $\mathrm{Fe}_{3} \mathrm{Zn}_{4}$ & 1,47 & $24,76 * \star$ \\
\hline $\mathrm{Fe}_{2} \mathrm{Zn}_{4}$ & 1,66 & $24,39 * *$ \\
\hline $\mathrm{Fe}_{3} \mathrm{Zn}_{4}$ & 6,73 & $14,45 * *$ \\
\hline $\mathrm{Fe}_{4} \mathrm{Zn}_{4}$ & 7,42 & $13,10 \star \star$ \\
\hline $\mathrm{Fe}_{0} \mathrm{Zn}_{4}$ & 7,47 & $13,00 * *$ \\
\hline $\mathrm{Fe}_{1} \mathrm{Zn}_{3}$ & 8,06 & $11,84 * *$ \\
\hline $\mathrm{Fe}_{0} \quad \mathrm{Zn}_{2}$ & 9,29 & $9,43 * *$ \\
\hline $\mathrm{Fe}_{1} \mathrm{Zn}_{2}$ & 9,66 & $8,71 * *$ \\
\hline $\mathrm{Fe}_{0} \mathrm{Zn}_{3}$ & 9,86 & $8,31 \star \star$ \\
\hline $\mathrm{Fe}_{2} \mathrm{Zn}_{3}$ & 9,89 & $8,25 * *$ \\
\hline Feo $Z n_{0}$ & 10,26 & $7,53 * \star$ \\
\hline $\mathrm{Fe}_{1} \mathrm{Zno}$ & 10,44 & $7,18 * *$ \\
\hline $\mathrm{Fe}_{3} \mathrm{Zn}_{3}$ & 11,18 & $5,73 *$ \\
\hline $\mathrm{Fe}_{2} \mathrm{Zn_{0 }}$ & 11,50 & $5,10 *$ \\
\hline $\mathrm{Fe}_{3} \mathrm{Zn}_{2}$ & 11,70 & $4,71 \mathrm{NS}$ \\
\hline $\mathrm{Fe}_{4} \mathrm{Zn}_{2}$ & 11,96 & 4,20 NS \\
\hline $\mathrm{Fe}_{0} \mathrm{Zn_{1 }}$ & 12,01 & $4,10 \mathrm{NS}$ \\
\hline
\end{tabular}


- Continuação -

\begin{tabular}{lll}
\hline Tratamentos & Mëdias & $\begin{array}{c}\text { Valores do Tes te de } \\
\text { Student }- \text { Newman - Keuls } \\
\text { para a Média } 14,10\end{array}$ \\
\hline $\mathrm{Fe}_{2} \mathrm{Zn}_{2}$ & 12,26 & $3,61 \mathrm{NS}$ \\
$\mathrm{Fe}_{3} \mathrm{Zn}_{0}$ & 12,44 & $3,25 \mathrm{NS}$ \\
$\mathrm{Fe}_{4} \mathrm{Zn}_{3}$ & 12,64 & $2,86 \mathrm{NS}$ \\
$\mathrm{Fe}_{2} \mathrm{Zn}_{1}$ & 13,19 & $1,78 \mathrm{NS}$ \\
$\mathrm{Fe}_{4} \mathrm{Zn}_{0}$ & 13,22 & $1,73 \mathrm{NS}$ \\
$\mathrm{Fe}_{1} \mathrm{Zn}_{1}$ & 13,49 & $1,20 \mathrm{NS}$ \\
$\mathrm{Fe}_{3} \mathrm{Zn}_{1}$ & 13,82 & $0,55 \mathrm{NS}$ \\
$\mathrm{Fe}_{4} \mathrm{Zn}_{3}$ & 14,10 & - \\
\hline
\end{tabular}

$\mathrm{Fe}_{0}-\cdots \mathrm{Fe}_{4}$ - Niveis de Ferro $(0,51-5,51-10,51-15,51-20,51 \mathrm{ppm})$

$Z n_{0}-\ldots Z n_{4}-N i v e i s$ de $Z$ inco $(0,45-5,45-10,45-15,45-20,45$ ppm)

NS - Não Significativo

* - Significativo $p \leq 0,05$

** - Significativo $p \leq 0,01$ 
Tabela 17. Anālise de Variância Referente à Produção de Proteina Bruta (gramas/litro) por Aspergillus niger IZ-9 em Meio de Amido de Mandioca e Urëia Onde Foram Testados Cinco Níveis de Zinco e Cinco de Ferro.

\begin{tabular}{lcccc}
\hline Causa de Variação & G.L. & S.Q. & Q.M. & F. \\
\hline Ferro & 4 & 2,93 & 0,73 & $14,60 *$ \\
Zinco & 3 & 3,93 & 1,31 & $26,20 * *$ \\
Interação Fe $\times$ Zn & 12 & 1,56 & 0,13 & $2,60 * *$ \\
\hline (Tratamentos) & $(19)$ & $(8,42)$ & $(0,44)$ & $(8,86 * *)$ \\
Residuo & 40 & 2,00 & 0,05 & \\
\hline Total & 59 & 10,42 & &
\end{tabular}

** - Significativo $p \leq 0,01$

C.V. $=9,5 \%$

Tabela 18. Decomposição da Interação Ferro x Zinco Relativa à Anālise de Variância Apresentada na Tabela 17.

\begin{tabular}{|c|c|c|c|c|c|c|}
\hline Causa & de Variaçao & G.L. & $S . Q$. & Q.M. & $F$ & \\
\hline \multirow{10}{*}{ Fe $x$} & $\mathrm{Zn}$ & 12 & 1,56 & 0,13 & 2,60 & ** \\
\hline & $\mathrm{Fe} / \mathrm{Zn} 0$ & 4 & 0,30 & 0,08 & 1,501 & NS \\
\hline & $\mathrm{Fe} / \mathrm{Zn}_{1}$ & 4 & 1,02 & 0,26 & $5,10 \times$ & $\star \star$ \\
\hline & $\mathrm{Fe} / \mathrm{Zn} \mathrm{n}_{2}$ & 4 & 1,64 & 0,41 & $8,20 x$ & *夫 \\
\hline & $\mathrm{Fe} / \mathrm{Zn}_{3}$ & 4 & 1,53 & 0,38 & 7,60 & $\star \star *$ \\
\hline & $\mathrm{Zn} / \mathrm{Fe}_{0}$ & 3 & 0,61 & 0,20 & $4,07 \times$ & * \\
\hline & $\mathrm{Zn} / \mathrm{Fe}_{1}$ & 3 & 2,60 & 0,87 & 17,40 & $* *$ \\
\hline & $\mathrm{Zn} / \mathrm{Fe}_{2}$ & 3 & 0,90 & 0,30 & 6,00 & ** \\
\hline & $\mathrm{Zn} / \mathrm{Fe}_{3}$ & 3 & 0,95 & 0,32 & 6,35 & $\star \star$ \\
\hline & $\mathrm{Zn} / \mathrm{Fe}_{4}$ & 3 & 0,43 & 0,14 & 2,87 & * \\
\hline \multicolumn{2}{|c|}{ Residuo } & 40 & 2,00 & 0,05 & & \\
\hline
\end{tabular}

NS - Não Significativo

*-. Significativo $p \leq 0,05$

$* *$ - Significativo $p \leq 0,01$ 
Tabela 19. Equações de Regressão que MeThor Estimam a Produção de Proteína Bruta por Aspergillus niger IZ-9 Relativas às Decomposições da Interação Ferro x Zinco Apresentadas na Tabela 18.

Decomposições

Equações de Regressão

$\begin{array}{ll}\mathrm{Fe} / \mathrm{Zn} & \hat{y}=2,48467+0,14500 x \\ \mathrm{Fe} / \mathrm{Zn}_{2} & \hat{y}=1,77399+0,20267 x \\ \mathrm{Fe} / \mathrm{Zn} \mathrm{n}_{3} & \hat{y}=1,94657-0,20080 x+0,09595 x^{2} \\ \mathrm{Zn} / \mathrm{Fe}_{0} & \hat{y}=2,20999+0,88617 x-1,08005 x^{2}+0,25390 x^{3} \\ \mathrm{Zn} / \mathrm{Fe}_{1} & \hat{y}=2,25333+2,32498 x-2,09332 x^{2}+0,41833 x^{3} \\ \mathrm{Zn} / \mathrm{Fe}_{2} & \hat{y}=2,26367+0,66699 x-0,24833 x^{2} \\ \mathrm{Zn} / \mathrm{Fe}_{3} & \hat{y}=2,41001+1,59548 x-1,31994 x^{2}+0,25443 x^{3} \\ \mathrm{Zn} / \mathrm{Fe}_{4} & \hat{y}=2,58000+1,38883 x-1,26161 x^{2}+0,26943 x^{3}\end{array}$

$Z n_{0}--Z n_{3}-$ Niveis de Zinco $(0,45-5,45-10,45-15,45 \mathrm{ppm})$

$\mathrm{Fe}_{0}--\mathrm{Fe}_{4}-$ Niveis de Ferro $(0,51-5,51-10,51-15,51-21,51 \mathrm{ppm})$

A comparação das mëdias pelo teste de Student-Newman - Keuls (Tabela 20) revelou que a maior média, produzida pela combinação dos níveis 4 "de ferro e 1 de zinco, não diferiu significativamente das obtidas nas com binações dos niveis 0 de zinco com 3 e 4 de ferro, 1 de zinco com qualquer outro de ferro, exceto o nivel zero, 2 de zinco com 2 e 4 de ferro e 3 de zinco com 4 de ferro. Todas as outras combinações mostraram diferença.

Foi determinado o teor de aminoácidos no microrganismo desenvolvido no meio de amido de mandioca e urēia com as doses 4 de ferro $(20,51$ ppm) e 1 de zinco $(5,45$ ppm) e comparado com com o padrão de aminoácidos es senciais determinado pela FAO (Tabela. 21). Verificou-se que o perfil de aminoācidos essenciais do micrörganismo determinado nestas condições foi comparāvel ao padrão da FAO apenas em relação ao teor de treonina, mostrando-se inferior em relação a todos os demais aminoácidos essenciais. 
Figura 3. Produção de Proteiึna Bruta por Aspergillus niger IZ-9 nos Nive is $1(\ldots .),. 2(\cdots-$.$) e 3(---)$ de Zinco, Respectivamente, $5,45-10,45$. e 15,45 ppm, em Função dos Níveis $0-1-2-3-$ e 4 de ferro, Respectivamerite, $0,57-5,57-10,51-15,51$ e $20,51 \mathrm{ppm}$.

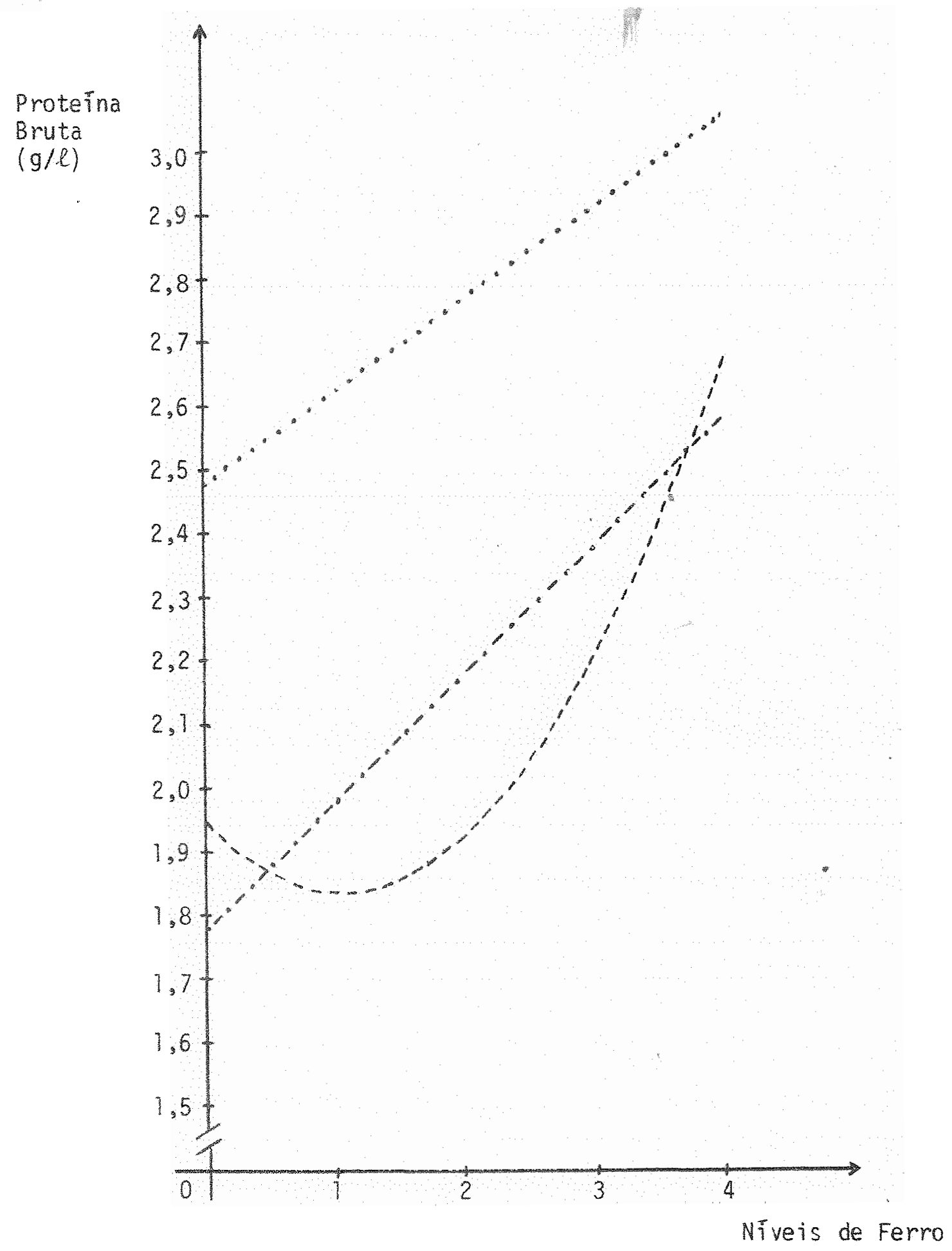


Figura 4. Produção de Proteina Bruta por Aspergillus niger IZ-9 nos Niveis $0(-), 1(\ldots), 2(-\ldots-), 3(---)$ e $4(-x-x-)$ de Ferro, Respectivamente, $0,51-5,51-10,51-15,51$ e $20,51 \mathrm{ppm}$, em Função dos Níveis $0-1-2$ e 3 de Zinco, Respectivamente, $0,45-5,45-10,45$ e $15,45 \mathrm{ppm}$.

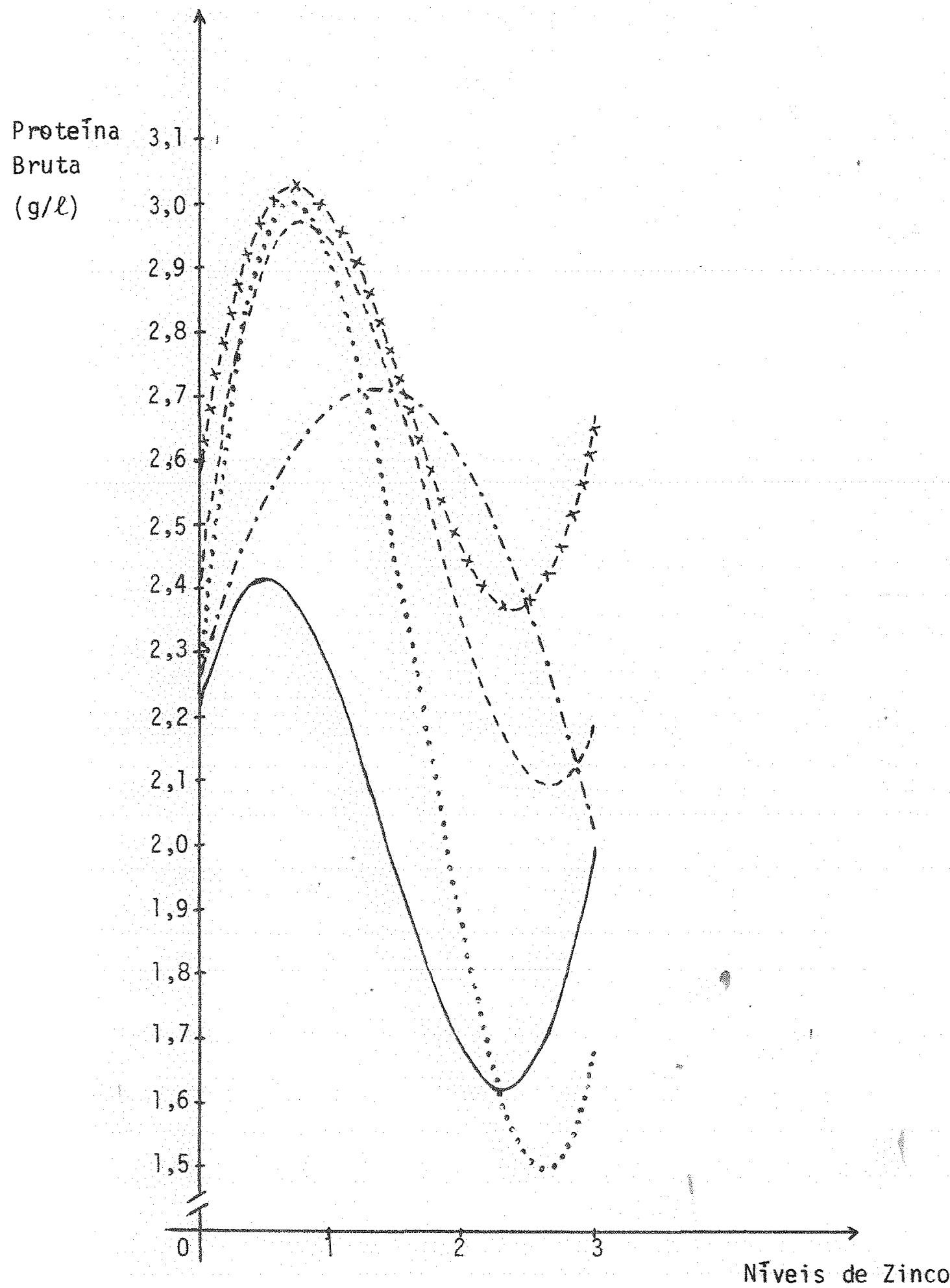


68.

Tabela 20. Teste de Student-Newman-Keuls para Comparação das Mëdias de Produção de Proteina Bruta (Gramas/litro) por Aspergillus niger. IZ-9 em Meio de Amido de Mandioca e Uréia Onde Foram Testados Cinco Niveis de Zinco e Cinco de Ferro.

\begin{tabular}{|c|c|c|}
\hline Tratamentos & Mēdias & $\begin{array}{l}\text { Valores do Teste de } \\
\text { Student - Newman - Keuls } \\
\text { para a Média } 2,98\end{array}$ \\
\hline $\mathrm{Fe}_{1} \mathrm{Zn}_{3}$ & 1,68 & $10,00 * *$ \\
\hline $\mathrm{Fe}_{0} \mathrm{Zn_{2 }}$ & 1,69 & $9,92 * *$ \\
\hline $\mathrm{Fe}_{1} \mathrm{Zn}_{2}$ & 1,88 & $8,46 \star \star \star$ \\
\hline $\mathrm{Fe}_{0} \mathrm{Zn}_{3}$ & 2,00 & $7,54 * *$ \\
\hline $\mathrm{Fe}_{2} Z \mathrm{Zn}_{3}$ & 2,06 & $7,08 \ldots *$ \\
\hline $\mathrm{Fe}_{3} \mathrm{Zn}_{3}$ & 2,79 & $6,08 * *$ \\
\hline $\mathrm{Fe}_{0} Z \mathrm{n}_{0}$ & 2,21 & $5,92 * *$ \\
\hline $\mathrm{Fe}_{2} \mathrm{Zn}_{0}$ & 2,23 & $5,77 *$ \\
\hline $\mathrm{Fe}_{1} Z \mathrm{Zn}_{0}$ & 2,25 & 5,62 * \\
\hline $\mathrm{Fe}_{0} \quad Z \mathrm{n}_{1}$ & 2,27 & $5,46 *$ \\
\hline $\mathrm{Fe}_{3} \mathrm{Zn}_{2}$ & 2,36 & 4,77 * \\
\hline $\mathrm{Fe}_{3} \mathrm{Zn}_{0}$ & 2,41 & $4,38 \mathrm{NS}$ \\
\hline $\mathrm{Fe}_{4} \mathrm{Zn}_{2}$ & 2,47 & 2,92 NS \\
\hline $\mathrm{Fe}_{2} \quad Z n_{2}$ & 2,50 & 3,69 NS \\
\hline $\mathrm{Fe}_{4} \mathrm{Zn}_{0}$ & 2,58 & 3,08 NS \\
\hline $\mathrm{Fe}_{4} \mathrm{Zn}_{3}$ & 2,67 & $2,38 \mathrm{NS}$ \\
\hline
\end{tabular}


- Continuação -

VaTores de Teste de

Tratamentos

Médias

Student - Newman - Keuls para a Média 2,98

$\mathrm{Fe}_{2} \mathrm{Zn_{1 }}$

2,78

1,54 NS

$\mathrm{Fe}, \mathrm{Zn} 1$

2,90

0,62 NS

$\mathrm{Fe}_{3} \mathrm{Zn}_{1}$

2,94

0,31 NS

$\mathrm{Fe}_{4} \mathrm{Zn}_{1}$

2,98

$\mathrm{Fe}_{0} \ldots \mathrm{Fe}_{4}$ - Niveis de Ferro $(0,51-5,51-10,51-15,51-20,51$ ppm)

$Z n_{0}=Z n_{3}-$ Niveis de Zinco $(0,45-5,45-10,45-15,45 \mathrm{ppm})$

NS - Não Significativo

* - Significativo $p \leq 0,05$

** - Significativo $\leq 0,01$ 
Tabela 21. Teor de Aminoäcidos em Aspergillus niger IZ-9 Apōs Quatro Dias de Incubação em Meio de Amido de Mandioca $(3,0 \mathrm{~g} \%$ de Carboidrato), Uréia $(0,12 \mathrm{~g} \%$ de Nitrogênio), Sulfato de Zinco $(5,45 \mathrm{ppm}$ de zinco) e Sulfato Ferroso $(20,51 \mathrm{ppm}$ de Ferro) em Comparação com o Padrão de Aminoäcidos Essenciais Determinado pela FAO.

\begin{tabular}{|c|c|c|c|}
\hline \multirow[t]{2}{*}{ Aminoäcido } & \multicolumn{2}{|c|}{$\frac{\text { A. }}{(g / 100} \frac{\text { giger }}{g \text { proteina })}$} & \multirow{2}{*}{$\begin{array}{l}\text { Aminoācidos Essen- } \\
\text { ciais (FAO) } \\
\text { (g/100 g proteina) }\end{array}$} \\
\hline & Totais & Essenciais & \\
\hline Lisina & 2,87 & 2,87 & 4,2 \\
\hline Histidina & 0,84 & - & - \\
\hline Arginina & 4,62 & - & - \\
\hline Ācido aspārtico & 4,32 & $\infty$ & - \\
\hline Treonina & 3,05 & 3,05 & 2,8 \\
\hline Serina & 1,83 & - & - \\
\hline Acido glutâmico & 7,00 & - & - \\
\hline Prolina & 2,33 & - & - \\
\hline Glicina & 2,67 & - & - \\
\hline Alanina & 3,73 & - & - \\
\hline Cistina & - & - & 2,0 \\
\hline Valina & 3,44 & 3,44 & 4,2 \\
\hline Metionina & 0,27 & 0,27 & 2,2 \\
\hline Isoleucina & 2,39 & 2,39 & 4,2 \\
\hline Leucina & 3,89 & 3,89 & 4,8 \\
\hline Tirosina & 2,12 & 2,12 & 2,8 \\
\hline Fenilalanina & 2,12 & 2,12 & 2,8 \\
\hline Triptofano & $N A^{2}$ & $N A^{a}$ & 1,4 \\
\hline Soma total & - & - & 31,4 \\
\hline - Triptofano & 47,49 & 20,15 & 30,0 \\
\hline
\end{tabular}

a - Não analisado 
Os valores do pH final dos meios foram determinados e estão a presentados na tabela 22. A estimativa da média foi 4,99 , tendo um desvio padrão de 0,228 .

Tabela 22. Valores do pH Final do Meio de Amido de Mandioca e Urëia Onde Foram Testados Cinco Niveis de Zinco e Cinco de Ferro para a Produção de Biomassa e Proteína Bruta por Aspergillus niger IZ9 (Médias de três repetições).

\begin{tabular}{llllll}
\hline & $Z n_{0}$ & $Z n_{1}$ & $Z n_{0}$ & $Z n_{3}$ & $Z n_{4}$ \\
\hline $\mathrm{Fe}_{0}$ & 3,67 & 4,73 & 4,13 & 4,30 & 4,20 \\
$\mathrm{Fe}_{1}$ & 3,83 & 5,60 & 4,03 & 4,00 & 7,90 \\
$\mathrm{Fe}_{2}$ & 3,93 & 5,07 & 5,17 & 4,70 & 7,70 \\
$\mathrm{Fe}_{3}$ & 4,70 & 5,67 & 5,73 & 4,27 & 4,03 \\
$\mathrm{Fe}_{4}$ & 5,40 & 5,40 & 5,63 & 5,77 & 4,03 \\
\hline
\end{tabular}

$Z n_{0} \ldots Z n_{4}-$ Niveis de $Z$ inco $(0,45-5,45-10,45-15,45-20,45 \mathrm{ppm})$

$\mathrm{Fe}_{0}-\mathrm{Fe}_{4}$ - Niveis de Ferro $(0,51-5,51-10,51-15,51-20,51 \mathrm{ppm})$ 
5.5. Ensaio de Cinco Niveis de Ferro $(15,51-20,51-25,51-30,51$ e 35,51 ppm) para o Crescimento de Aspergillus niger IZ-9 em Meio de Amido de Mandioca $(3,0$ gramas Carboidrato por Cento), Uréia $(0,12$ gramas de Nitrogēnio por Cento) e Zinco $(5,45 \mathrm{ppm})$.

Os resultados, avaliados em termos de produção de biomassa e proteĩna bruta, estão apresentados nas tabelas 23 e 24 , respectivamente.

Tabela 23. Produção de Biomassa (Peso Seco em gramas/litro) por Aspergillus niger IZ-9 em Meio de Amido de Mandioca e Uréia Onde Foram Testados Cinco Niveis de Ferro Fixando-se o Zinco na Concentração de 5,45 partes por milihão.

\begin{tabular}{lccccc}
\hline $\begin{array}{l}\text { Tratamentos } \\
\text { (ppm de Fe) }\end{array}$ & I & II & III & Médias a & Médias b \\
\hline 15,51 & 9,47 & 8,58 & 7,82 & 8,63 & 8,63 \\
20,51 & 9,18 & 9,28 & 8,60 & 9,02 & 9,02 \\
25,51 & 17,14 & 0,02 & 8,88 & 6,68 & 10,01 \\
30,51 & 9,12 & 8,60 & 17,15 & 9,62 & 9,62 \\
35,51 & 9,78 & 8,12 & 0,07 & 5,97 & 8,95 \\
\hline
\end{tabular}

a - Médias levando-se em consideração todas as repetições de todos os trata mentos.

b - Médias eliminando-se as repetições II e III dos tratamentos com 25,51 e $35,51 \mathrm{ppm}$ de ferro, respectivamente. 
Tabela 24. Produção de Proteina Bruta (gramas/litro) por Aspergillus niger IZ-9 em Meio de Amido de Mandioca e Uréia Onde Foram Testados Cinco Niveis de Ferro Fixando-se o Zinco na Concentração de 5,45 partes por milhão (Médias de três repetições para os tratamentos com 15,51-20,51 e 30,51 ppm de ferro e duas para os tratamentos com 25,51 e 35,51 ppm do elemento).

Tratamentos

(ppm de $\mathrm{Fe}$ )
Proteina Bruta

$(g / \ell)$

$\begin{array}{ll}15,51 & 1,74 \\ 20,51 & 1,86 \\ 25,51 & 2,07 \\ 30,51 & 1,96 \\ 35,51 & 1,82\end{array}$

Em relação à produção de biomassa, observou-se uma baixa produçäo numa das repetições dos tratamentos com 25,51 e 35,51 ppm de ferro. Por este motivo, foi feita uma anälise de variáncia considerando todos os resultados obtidos (Tabela 25), cujo coeficiente de variação foi de $45 \%$ e outra desprezando as repetiçōes acima referidas (Tabela 26), na qual foi obtido um coeficiente de variação de $11,64 \%$. Em ambos os casos não foi encontrada diferença entre os tratamentos, indicando que as variações obser vadas não foram causadas pelos tratamentos, mas por algum fator não contro\}ado.

A produçäo de biomassa foi correlacionada com o pH final dos meios (Tabela 27), tendo-se encontrado um coeficiente de correlação linear de $r=-0,95,0$ qual, pelo teste $t$, mostrou-se ser altamente significativo 
Tabela 25. Anāilise de Variāncia Referente à Produção de Biomassa por Aspergillus niger IZ-9 Apresentada na Tabela 23 Considerando - se Todos os Resultados Obtidos.

\begin{tabular}{lcccc}
\hline Causa de variação & G.L. & S.Q. & Q.M. & F. \\
\hline Tratamentos & 4 & 29,79 & 7,45 & 0,58 NS \\
Residuo & 10 & 129,01 & 12,90 & \\
\hline Totâl & 14 & 158,80 & & \\
\hline
\end{tabular}

NS - Não Significativo

C.V. $=45 \%$

Tabela 26. Anälise de Variāncia Referente à Produção de Biomassa por Aspergillus niger IZ-9 Apresentada na Tabela 23 Eliminando-se as Repetições II e III dos Tratamentos com 25,51 e 35,51 partes por milhão de Ferro, Respectivamente.

\begin{tabular}{lcccc}
\hline Causa de variação & G.L. & S.Q. & Q.M. & F \\
\hline Tratamentos & 4 & 3,06 & 0,77 & 0,67 NS \\
Resíduo & 10 & 9,79 & 1,15 & \\
\hline Total & 14 & 12,25 & \\
\hline
\end{tabular}

NS - Não Significativo

C.V. $=11,64 \%$

a nivel de $1 \%$ de probabilidade, indicando que $90,3 \%$ da redução na produção de biomassa ocorreu onde houve aumento no $\mathrm{pH}$. 
Tabela 27. Produção de Biomassa por Aspergillus niger IZ-9 em Meio de Amido de Mandioca e Urëia Onde Foram Testados Cinco Niveis de Ferro Fixando-se o Zinco na Concentração de $5,45 \mathrm{ppm}$. Valores do pH Final dos Meios e Coeficiente de Correlação Linear.

\begin{tabular}{|c|c|c|c|c|c|c|}
\hline \multirow{3}{*}{$\begin{array}{l}\text { Tratamentos } \\
\text { (ppm de Fe) }\end{array}$} & \multicolumn{6}{|c|}{ Repetições } \\
\hline & \multicolumn{2}{|l|}{ I } & \multicolumn{2}{|l|}{ II } & \multicolumn{2}{|l|}{ III } \\
\hline & $\begin{array}{c}\text { Biomassa } \\
(g / \ell)\end{array}$ & $\begin{array}{c}\mathrm{pH} \\
\text { Final }\end{array}$ & $\begin{array}{c}\text { Biomassa } \\
(g / \ell)\end{array}$ & $\begin{array}{c}\mathrm{pH} \\
\text { Final }\end{array}$ & $\begin{array}{c}\text { Biomassa } \\
(g / \ell)\end{array}$ & $\begin{array}{c}\mathrm{pH} \\
\text { Final }\end{array}$ \\
\hline 15,51 & 9,47 & 3,5 & 8,59 & 3,8 & 7,82 & 3,7 \\
\hline 20,51 & 9,18 & 3,3 & 9,28 & 3,7 & 8,60 & 3,6 \\
\hline 25,51 & 11,74 & 3,6 & 0,02 & 8,0 & 8,88 & 3,5 \\
\hline 30,51 & 9,12 & 3,9 & 8,60 & 3,8 & 11,15 & 4,0 \\
\hline 35,51 & 9,78 & 3,7 & 8,12 & 3,7 & 0,01 & 8,0 \\
\hline \multicolumn{7}{|c|}{ Coeficiente de Correlação Linear $=-0,95$} \\
\hline Valor do Tes & $t=10$ & $\star \star$ & & & & \\
\hline
\end{tabular}

** - Significativo $p \leq 0,01$

A anālise de variāncia relativa à produção de proteina bruta (Tabela 28) mostrou não haver diferença significativa entre os tratamentos. 
Tabela 28. Anālise de Variância Referente à Produção de Proteína Bruta (gramas/litro) por Aspergillus niger IZ-9 Apresentada na Tabela 24.

\begin{tabular}{lcccc}
\hline Causa de Variação & G.L. & S.Q. & Q.M. & F. \\
\hline Tratamentos & 4 & 0,75 & 0,038 & 0,63 NS \\
Residuo & 8 & 0,44 & 0,06 & \\
\hline Total & 12 & 0,59 & 0,049 \\
\hline
\end{tabular}

NS - Näo significativo

C.V. $=12,77 \%$ 
5.6. Curva de Crescimento do Aspergillus niger IZ-9 em Meio de Amido de Mandioca (3,0 gramas de Carboidrato por Cento), Uréia (0,12 gramas de Nitrogēnio por Cento), Sulfato de Zinco $(5,45 \mathrm{ppm}$ de Zinco) $\mathrm{e}$. Sulfato Ferroso $(20,51 \mathrm{ppm}$ de Ferro).

Em intervalos de 12 horas, num período de 24 a 144 horas, o crescimento do microrganismo foi paralisado e determinada a produção de biomassa (peso seco), proteina bruta e pH final dos meios. Durante as primeiras 36 horas nenhum crescimento foi observado, tendo sido a primeira medida de peso seco efetuada após 48 horas. As biomassas produzidas apōs 48 e 60 horas não foram suficientes para permițir a anālise de proteina bruta, razão pela qual esta só foi realizada a partir de 72 horas (Tabela 29).

A anālise de variāncia relativa à produção de biomassa mostrou que foram significativos apenas os componentes de primeiro e segundo graus (Tabela 30), enquanto que em relação à produção de proteína bruta não foi encontrada diferença significativa em nenhum dos componentes (Tabela 31).

A equação de regressão que melhor se adaptou aos valores de peso seco obtidos foi a seguinte: $\bar{y}=-12,07114+0,36235 x-0,00146 x^{2}$. A respectiva curva estā representada na figura 5 .

A comparação das médias de produção de biomassa pelo teste de Student-Newman-Keuls (Tabela 32) mostrou que o māximo de produção foi alcançado a partir de 120 horas.

Os valores do $\mathrm{pH}$ final dos meios tiveram uma média de 3,57 com um desvio padrão de 0,241 . 
Tabela 29. Produção de Biomassa (Peso Seco em gramas/litro) e Proteína Bru ta (gramas/7itro) por Aspergillus niger IZ-9 em Meio de Amido de Mandioca (3,0 gramas de Carboidrato por Cento), Uréia $(0,12$ gramas de Nitrogênio por Cento), Sulfato de Zinco (5,45 ppm de Zinco) e Sulfato Ferroso $(20,51$ ppm de Ferro) para Determinação da Curva de Crescimento e Valores do pH Final dos Meios (Médias de três repetições).

\begin{tabular}{lccc}
\hline Horas & $\begin{array}{c}\text { Peso Seco } \\
(\mathrm{g} / \ell)\end{array}$ & $\begin{array}{c}\text { Proteina Bruta } \\
(\mathrm{g} / \ell)\end{array}$ & $\mathrm{pH}$ Final \\
\hline 24 & - & - & 3,0 \\
36 & - & - & 3,0 \\
48 & 2,09 & - & 5,8 \\
60 & 3,81 & - & 3,9 \\
72 & 6,96 & 1,39 & 3,8 \\
84 & 8,50 & 1,80 & 3,3 \\
96 & 8,76 & 1,70 & 3,1 \\
108 & 10,33 & 1,62 & 3,2 \\
120 & 9,66 & 1,67 & 3,2 \\
132 & 10,97 & 1,86 & 3,4 \\
144 & 9,72 & 1,45 & 3,6 \\
\hline
\end{tabular}


Tabela 30. Anālise de Variāncia Referente à Produção de Biomassa por Aspergillus niger IZ-9 Apresentada na Tabela 29.

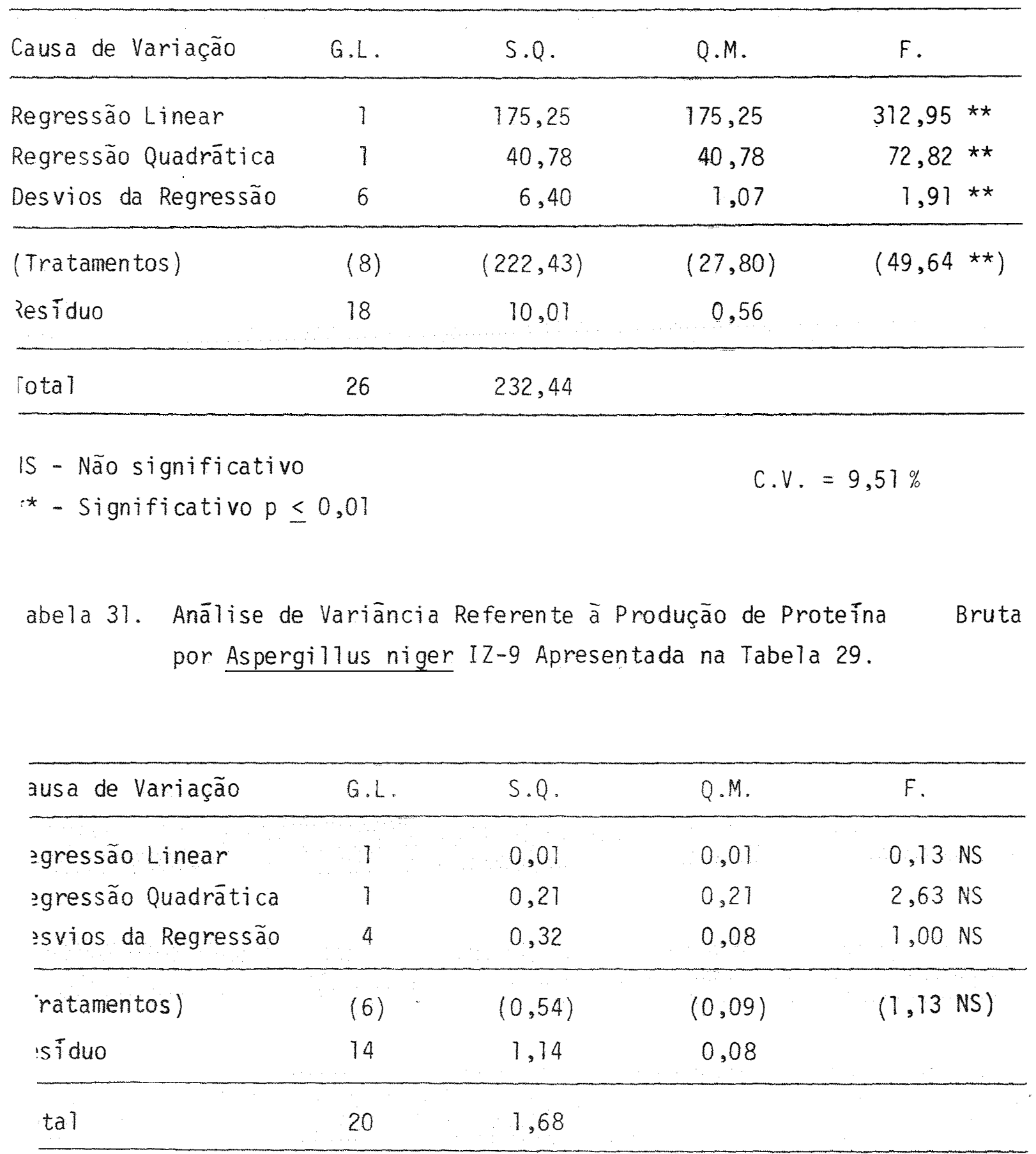

- Näo Significativo 
80.

Tabela 32. Teste de Student-Newman-Keuls para Comparação das Mëdias de Produção de Biomassa (Peso Seco em gramas/litro) por Aspergillus niger IZ-9 Apresentada na Tabela 29.

\begin{tabular}{lcc}
\hline Horas & Médias & $\begin{array}{l}\text { Valores do Teste de } \\
\text { Student-Newman-Keuls } \\
\text { para a Média 10,97 }\end{array}$ \\
\hline 48 & 2,09 & $20,65 * *$ \\
60 & 3,81 & $16,65 * *$ \\
72 & 6,96 & $9,33 * *$ \\
84 & 8,50 & $5,74 * *$ \\
96 & 8,76 & $5,14 *$ \\
120 & 9,66 & $3,05 \mathrm{NS}$ \\
144 & 9,72 & $2,91 \mathrm{NS}$ \\
108 & 10,33 & $1,49 \mathrm{NS}$ \\
132 & 10,97 & - \\
\hline
\end{tabular}

NS - Não Significativo

* - Significativo $p \leq 0,05$

$* *$ - Significativo $p \leq 0,01$ 
Figura 5. Produção de Biomassa por Aspergillus niger IZ-9 em Meio de Amido de Mandioca, Uréia, 5,45 ppm de Zinco e 20,51 ppm de Ferro Durante o Período de 48 a 144 horas

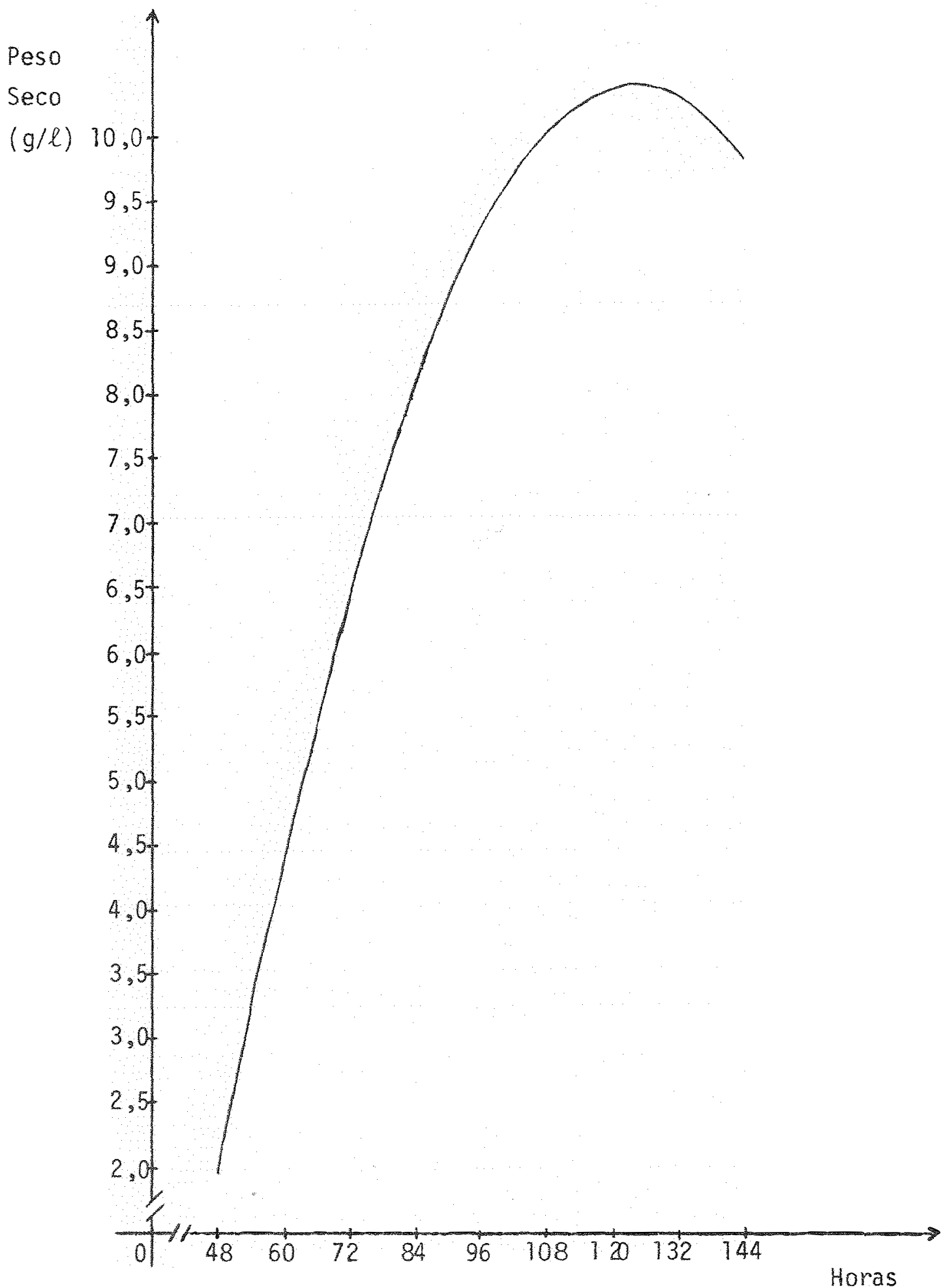


82.

6. DISCUSSAOO

6.7. Seleção do Mi corganismo e Determinação do pH ótimo

0 não crescimento de Fusarium sp em pH 2 pode ter sido devido ao efeito do pH do meio sobre processos fisiológicos, tais como sintese de metabōlitos essenciais (fatores de crescimento, ATP e proteínas), inativação de enzimas e permeabilidade da membrana, através da alteração no pH interno da célula ou por simples saturação da membrana celular por ỉons hidrogênio.

Em relação aos fatores de crescimento, LILLY e BARNETT (1951) relatam o efeito do pH sobre a sintese de tiamina em Sordaria fimicola.

A sintese de ATP pode ser reduzida ou, até mesmo, paralisada pela saturação da superfície externa da membrana mitocondrial externa com ions hidrogēnio, carregando sua parte. interna negativamente. De acordo com a hipōtese quimiosmótica, os gradientes de pH e de potencial elétrico gerados pela cadeia respiratória garantem a inversão do sentido da reação catalisada pela ATPase de modo a realizar sintese de ATP. Esses gradientes são formados pela passagem de ions hidrogēnio da matriz para o espaço intermem- 
branar, mediante transportadores, e retenção de eletrons. Desta,forma, a superficie externa da membrana interna se carrega positivamente e a matriz, negạtivamente. Uma vez estabelecidos os dois gradientes, a molécula de āgua liberada durante a sintese de ATP, ocorrida na membrana interna, se dissocia indo o Ton hidrogênio para a matriz e o jon hidroxila paralo espaço inter membranar. Se a superficie interna da membrana externa da mitocōndria estiver carregada negativamente as cargas positivas geradas durante 0 transportét de elefrons serão neutralizadas por cargas negativas restabelecendo o equilibrio e, portanto, paralisando a sintese de ATP:

A inativação de enzimas decorrente da alteração no pH interno da célula é explicada por um efeito sobre o carater iônico de proteỉnas, tais como enzimas, afetando seus sitios cataliticos e conformaçōes estruturais.

A saturaçào da membrana celular por ions hidrogēnio leva a uma alteração na permeabilidade da mesma a cātions essenciais para o desenvolvimento do microrganismo em quantidades adequadas.

Supondo ter havido hidrölise da uréia durante a autoclavagem, ou por ação enzỉmica, a ausencia de crescimento pode ser explicada, ainda, pela alteração nas cargás de proteỉnas da membrana celular, principalmente daquelas que fazem parte do sistema de transporte de amonio. RooN et alii (1975), analisando o transporte de metilamina e amōnia em Saccharomyces cerevisiae, verificaram que pela estimativa da velocidade máxima (Vmáx) e constante de Michaelis a amónia era um inibidor competitivo da metilamina. A passagem desta para o interior da célula exigia fonte de energia, sugerin do que o transporte se dava por um mecanismo ativo. Trabalhando com mutantes com pouca capacidade de transportar metilamina os autores observaram a mesma deficiencia para o transporte de amōnia. Com isto, pretenderam 
mostrar que a amônia e a metilamina participam de um sistema comum de trans porte.

Se não houve hidrōlise da urēia na autoclavagem, ou por açăo enzỉmica, esta fonte de nitrogênio deve ser transportada para o interior da cēlula a fim de que possa ser utilizada. Quanto ao mecanismo de transporte COOPER e SUMRADA(1975) acharam que em Saccharomyces cerevisiae o trans porte de urēia em baixa concentração ē dependente de energia e em concentrações externas excessivas se dá por difusão passiva ou facilitadá. Em pH 2 o não crescimento do Fusarium sp pode revelar um efeito do pH sobre o mecanismo de transporte de urēia.

A baixa produção observada em toda a faixa de $\mathrm{pH}$ entre 3 e 9 parece indicar a presença de uma ou mais substāncias essenciais para o cres cimento em quantidades inadequadas e que o pH não exerceu influência sobre o desenvolvimento do microrganismo, como ficou demonstrado pela anālise estatística.

0 ajustamento do $\mathrm{pH}$ em todos os valores iniciais para valores em torno de 8,3 pode significar a presença de ion amōnio $\left(\mathrm{NH}_{4}^{+}\right)$, nos casos onde houve elevação de $\mathrm{pH}$, ou äcidos orgānicos, onde houve redução. No pri meiro caso, o ion amōnio resulta da reação do ĩon hidrogênio, encontrado na solução, com a amōnia liberada, durante a autoclavagem ou por ação enzîmi ca, e pouco utilizada pelo microrganismo.

Aspergillus niger IZ-9 e Aspergillus wentii IZ-1625, tendo crescido em pH 2, mostram ser mais tolerantes a pH ācido que o Fusarium sp. Esta diferença se deve provavelmente às caracterỉsticas físico-químicas das enzimas envolvidas nos si.stemas de transporte e sintese. 
0 marcante decréscimo na produção de biomassa ocorrido no $\underline{A}$. niger IZ-9 à medida que se eleva o pH pode ser explicado pela exigência de maior quantidade de oxigênio disponīvel pelo microrganismo, uma vez que em cultura submersa, a quantidade de oxigênio disponível ê maior em meio ácido do que em alcaiino. Além disso, a redução no crescimento pode ser também devida à deficiência de cătions essenciais que se tornaram insolūveis à medida que o pH foi se tornando alcalino. Um ion, como por exemplo, o ion férrico $\left(\mathrm{Fe}{ }^{+++}\right)$ou fosfato $\left(\mathrm{PO}_{4} \equiv\right)$, em solução alcalina, pode se tornar não disponível por formar compostos insolüveis. Porém, para manter o equîībrio quỉmico, existem, na solução, para os exemplos dados, ferro e fosfato na forma iônica e, portanto, disponível. A medida que estes ions vão sendo utilizados, o precipitado irā aos poucos se dissolvendo. O A niger IZ-9 po de necessitar da presença, na solução, de quantidades de ions disponíveis numa concentração mais al ta que aquela mantida pelo equilíbrio. Neste caso, sō em pH àcido é que ocorrerão as melhores produções. Com base nesta nipōtese e pelo menor grau de sensibilidade à variação de pH inicial (Tabe1a 6) O A.wentii IZ-1625 parece exigir a presença de menor concentração de ions essenciais. A solubilização de certos ions, como ferro, em pH alcalino, segundo LILLY e BARNETT (1951), se dá de modo marcante na presença de àcidos orgānicos, como os àcidos cîtrico, mālico e tartárico. sendo o A. niger um bom produtor de ácido cĩtrico, a ação evidente deste àcido se féz presente no pH inicial 6 , que foi reduzido para 3,8 (Tabela 1) promoven do a solubilização de ĩons essenciais e, consequentemente, favorecendo 0 crescimento do microrganismo neste valor de $\mathrm{pH}$ inicial em relação aos valores 7,8 e 9 (Tabela 7). Apesar de ter havido produção de āci do em pH 7,8 e 9 não foi suficiente para promover a solubilização de ions em proporções adequadas ao crescimento. 
A alteração ne crescimento pode ter sido influenciada, ainda, pela açã de determinada concentração hidrogeniönica sobre a produção de amilase, necessāria ähidrölise do amido, ou transporte de gỉcose. LINEBACK et alij (1955) encontraram que a atividade da glicoamilase produzida por Aspergillus niger näo foi afetada pelo pH s poem relatam que, provavel mente, a concentração hidrogeniónica inflúu sobre a capacidade do fungo de sintetizar a enzima. No ph 2, apesar da hidrólise äcida do emido em elevam da temperatura, o Fusarium sp não apresentou crescimento. Isto, provavelmente foi devido, entre outros fatores, $\bar{a}$ açäo do ph sobre o transporte de g]icose.

Entre os microrganismos testados, A.niger $12-9$ em pH 2, 3 e 4 e o Fusarium sp em todos os valores de pH foram os mais estaveis em termos de produção de massa micelial. No entanto, a baixa produção do Fusarium sp toma-o não indicado para esta finalidade nas condiçöes de cultura em que foi testado. 0 A. wentil IZ-1625 em pH 2 e 3 apresentou uma certa instabilidade. Apesar deste fungo no pH 3 não ter apresentado diferença significativa em comparaçäo com as produçöes do A. niger $12-9$ em pH 2,3e 4, o ultimo foi escolhido por sua maior estabilidade na faixa de pH desejavel para trabalhos desta natureza, onde problemas de contaminação devem ser minimizados. 0 pH 3 foi utilizado nos testes subsequentes, pois uma alteração no pH pelo prö rio metabolismo do microrganismo numa faixa de 2 a 4 não afeta a produção. 
6.2. Ensaio de Duas Fontes de Nitrogēnio (Uréia e Nitrato de Amönio) para o Crescimento de Fusarium sp., Aspergillus niger IZ-9 e Aspergillus wentii IZ-1625 em Meio de Amido de Mandioca.

Este ensaio foi elaborado com o intuito de se verificar o efeito da pré-hidrōlise da uréia sobre o desenvolvimento dos fungos em estudo, uma vez que sabe-se que, ao ser autoclavada, a uréía sofre hidrölise com conseqüente liberação de amōnia. Com base na composição quỉmica da urē ia, foi escolhido o nitrato de amōnio para servir como padrão, pois ambos os compostos possuem dois átomos de nitrogénio em suas moléculas, embora no primeiro caso esses dois átomos estejam sob a forma de amina e no segundo um sob a forma de amōnio e o outro sob a forma de nitrato. Além disso, foi encontrado que as duas fontes de nitrogénio mantêmo pH final do meio próximo do inicial não havendo necessidade de reajuste durante o processo e que não hä diferença entre as duas fontes quanto à produção de proteỉna por Aspergillus fumigatus, tendo sido preferida a uréia por apresentar um coe ficiente de conversão mais al to que o nitrato de amōnio (READE e GREGORY, 1975).

Durante a hidrōilise da uréia duas moléculas de amōnia e uma de diōxido de carbono säo formadas. Nos sistemas biolögicos esta hidrōlise se dä através de enzimas como a uréia carboxilase e alofanato hidrolase. Ve rificou-se que as moléculas de amōnia entram na célula numa taxa mais räpida que sua remoção por assimilação atē que se estabeleça um nîvel de equil $\underline{\underline{I}}$ brio no interior da célula, sendo que a concentração de equilîbrio não depende do metabolismo, mas da concentração externa, e, ainda, sugeriu-se que o transporte da amônia se dā de maneira passiva (MACMILLAN, 1956). Entre. tanto, HACKETTE et alij(1970) acham que a maioria dos microrganismos utiliza 
o ion amōnio através de um sistema de transporte altamente específico no lugar da amōnia. Não acham provāvel que a amōnia seja transportada porque - valor aparente da constante de Michaelis para o transporte do ion amónio foi muito baixo $\left(2,5 \times 10^{-7} \mathrm{M}\right)$, devendo ser o da amónia ainda cerca de 3 ordens de grandeza mais baixo.

Independentemente do sistema de transporte da amônia ou ion amónio, a uréia parece ser mais adequada ao crescimento de microrganismos que o nitrato de amōnio por fornecer duas moléculas de amônia por molécula hidrolisada. Para que o nitrato de amōnio desse uma molécula de amōnia seria necessārio que um sistema de enzimas, a inda não bem determinado, incluindo nitrato, nitrito, hiponitrito e hidroxilamina redutases, fosse mobilizado para realizar reduçōes sucessivas sobre o nitrato. Nestas reduções seriam necessārias vārias moléculas de NAD ou NADP reduzidas como fontes de eletrons. Como para a utilização de cada uma dessas moléculas duas de ATP são deixadas de ser sintetizadas, a cēlula pode sofrer, durante este processo de redução, um decréscimo na relação ATP/ADP + Pi, necessitando, assim, de uma maior velocidade de oxidação de substrato para restaurar ou manter a relação ótima. A hidrōlise enzimica da uréia necessita apenas de uma molécula de ATP. Portanto, o simples balanço energético pode explicar a superioridade da uréia em relação ao nitrato de amônio observada no presente ensaio. Além disso, o ion amōnio pode inibir a utilização de nitrato de modo que, num determinado tempo, o nümero de àtomos de nitrogēnio disponỉvel para a célula seja menor no meio contendo nitrato de amónio que no contendo urëia. MORTON e MACMILLAN (1954), analisando a assimilação de nitrogēnio inorgānico por Scopulariopsis brevicaulis, verificaram que a amōnia inibe completamente a utilização de nitrato interferindo na redução do nitrato a nitrito. Os autores acreditam que este fenōmeno $\vec{e}$ geral em 
fungos, porēm em algumas espécies, tais como A. niger. A. oryzae, Fusarium graminearum e Penicillium griseofulvum, o nitrato parece ser utilizado ao mesmo tempo que a amōnia, embora numa taxa relativamente baixa. A ação inibitöria do fon amōnio sobre a utilização do nitrato em fungos, de um modo geral, se deve possivelmente ao fato destes microrganismos reduzirem 0 nitrato apenas quando seu nitrogēnio é exigido. Como o nitrogénio do ion amōnio está numa forma mais disponîvel, o nitrogēnio do nitrato é incorpo rado ao material celular quando todo ou, pelo menos, parte do ion amónio é consumido. COCHRANE (1958) relata que a redução do nitrato em fungos sö ocorre durante a incorporação do seu nitrogénio na cëluia, ao contrário das bactêrias que reduzem o nitrato sem que haja assimilação.

Uma vez no interior da célula, a amōnia é incorporada a esque letos carbōnicos através de enzimas como desidrogenase glutämica e aspartase. A primeira, por realizar uma reação reversivel que consiste na transformação do ācido L - glutāmico em àcido a-cetoglutārico e amōnia, desempenha uma das mais importantes funções nos sistemas biorögicos incorporando a amōnia ao ácido $\alpha$-cetoglutárico para a produção de compostos nitrogenados. A segunda catalisa outra reação reversivel na qual o äcido L-aspārtico se transforma em äcido fumārico e amōnia. Do mesmo modo, a amōnia pode ser introduzida num esqueleto carbōnico. A diferença no crescimento entre as duas fontes pode ser influenciada pela velocidade com que esta incorporação é realizada uma vez que a velocidade de reação depende, até certo ponto, da concentração do substrato.

Em pH äcido, o nitrito resultante da redução do nitrato pode exercer um efeito töxico sobre microrganismos (COCHRANE, 1958), o que pode ser uma explicação para o não crescimento do Fusarium sp. em nitrato de 
amonio. Este efeito tōxico talvez esteja relacionado com a deficiéncia" na sintese ou baixa atividade da nitrito redutase em pH äcido levando, conse qüentemente, a um acumulo deste íon no meio. A alteração do pH ocorrida no meio de nitrato onde näo foi observado crescimento do Fusarium sp. pode ter sido causada por alguma atividade das enzimas do inóculo na tentativa do microrganismo iniciar seu desenvolvimento em valores de mais elevados. Sua sensibilidade ao nitrato de amōnio, ou a substäncias resultantes da reduçăo do nitrato, nao permitiu uma elevaçao do pH suficiente para o cresci. mento.

6.3. Ensaios de Cinco Niveis de Zinco $10,45-5,45-10,45-15,45$ e 20,45 ppm) com cinco de Ferro $(0,51-5,51-10,51-15,51$ e 20,5$] \mathrm{ppm})$ e de Cinco de Ferro $(15,57-20,51-25,51-30,51$ e 35,51 ppm) Fixando o Zinco na Concentração de 5,45 ppm para o Crescimento de Aspergillus niger IZ-9 em Meio de Amido de Mandioca 13,0 gramas de Carboidrato. por Cento) e Uréja $(0,12$ gramas de Nitrogénio por Cento).

Os resultados apresentados no primeiro ensaio indicaram que as quantidades de, pelo menos um dos elementos, zinco ou ferro, presentes no amido de mandioca utilizado não foram suficientes para apresentar uma interação favorável ao mäximo crescimento do aicrorganismo. Para tal, a adiçăo de zinco foi mais favorävel no nivel 1 (5,45 ppm) enquanto que o fer ro produziu meihores resultados nos niveis $3(15,51 \mathrm{pm})$ e $4(20,51 \mathrm{ppm})$, mesmo no nivel zero de zinco, indicando que a quantidade de ferro, pelo menos dentro de certos limites de zinco, restaura o crescimento mäximo quan do quantidades, mesmo insuficientes, do ultimo elemento estäo presentes. Is to näo concorda com dados relatados por LILLY e BARNETT (1951), OS quais 
indicam que se a concentração de zinco for baixa a adição de ferro ao meio livre do mesmo resulta num efeito pouco expressivo. Esta discrepāncia pode estar relacionada com diferenças individuais do microrganismo ou com o fato de que a quantidade de 0,45 ppm de zinco não seja suficientemente baixa. (Tabela 16).

A participação mais importante do ferro nos processos de sintese se deve, provavelmente, à presença deste metal em macromoléculas como RNA, citocromos e em muitos sistemas enzimicos. Alëm de atuar como catalisador de reações enzỉmicas pode catalisar reações não enzîmicas. possivel que os niveis $0-1$ e 2 de ferro dentro do nível zero de zinco favoreçam a produção e acúmulo de ácidos intermediārios do ciclo de Krebs. Sen do a oxidação total de carboidratos dependente da concentração de citocro mos disponĩvel, o acúmulo desses àcidos pode revelar alteração no metabolis mo do microrganismo, possivelmente, por falta de ferro suficiente para síntese de tais moléculas. Is to concorda com os dados obtidos por TOMLINSON et alii (1950), segundo os quais, de um modo geral, as quantidades de ferro exigidas para uma alta produção de ācido cĩtrico săo menores que as necessä rias para o bom crescimento do microrganismo.

o zinco apresentou um efeito estimulatörio em determinados nĩveis e töxico em níveis mais elevados (Figuras 2 e 4). O seu papel estimulatörio na produção de massa micelial e proteinna está relacionado com uma série de fatores, tais como, participação na estrutura de macromoléculas in dispensäveis aos dois processos conferindo-Thes estabilidade, utilização mais completa da fonte de carbono, inibição da sintese de determinadas subs täncias orgãnicas como lipĭdeos, por exemplo, e participação na sĩntese de certas enzimas. A integridade e estabilidade dos ribossomos dependem da 
presença de Tons de zinco (TAL, 1969 e CHVAPIL, 1973). Estando o metal envolvido nos sistemas de polimerização a sua presença em quantidades insuficientes pode comprometer a sintese de RNA, proteina, e outras substäncias celulares. A presença de 2 a 4 átomos-grama de zinco por mol de RNA polime rase no bacteriōfago $T_{7}$, sua redução em moléculas inativadas e aumento da atividade catalîtica em decorrência da sua adição observados por COLEMAN (1974) reforçam a importáncia do elemento na produção de substâncias celula res, principalmente de RNA e proteina. O envolvimento do metal na sintese proteica e massa celular foi encontrado também na fisiologia do trigo como sendo devido, possivelmente, ao seu estimulo sobre a 'produção de RNA (SACHDEV e DEB, 1977). Foi observado que a sintese de lipideos era inibida pela adiçã de zinco à cultura de Rhodotorula gractilis deficiente neste metal (CO CUCCI e ROSSI, 1972). A ação do elemento sobre a sintese de Tipideos se dä, provavelmente, pela sua interferência na oxidação de MADP reduzido. Hä, des ta forma, um aumento na relação NADPH:NADP tão necessāria à sỉntese, porëm a forma reduzida não está totalmente disponìvel para o processo. Esta interferência pode ser de grande importāncia, uma vez que o material orgānico e a energia gastos para a sintese deste composto podem ser utilizados para a Sintese de RNA, proteinas e outros materiais celulares. 0 zinco atua, ainda, na sintese de muitas enzimas, entre as quais a carboxilase pirúvica (FOSTER e DENISON, 1950), a glutámico desidrogenase (CANTAROH, 1968) e o sistema enzimico que sintetiza o triptofano (NASON, 1950 e NASON et alii, 1951). Atuando sobre a glutämico-desidrogenase afeta, pois, o metabolismo do nitrogènio e sobre a sintese de triptofano influencia o sistema de trans porte de eletrons, uma vez que este aminoäcido ê um precursor da nicotinami da, a qual faz parte da molécula do NAD ou NADP. Neste ültimo caso, tambëm 
o ferro tem uma participação, pois estä presente na molēcula de triptofano pirrolase, enzima que oxida o triptofano a formilquinurenina na via da sin tese da nicotinamida. Deste modo, pode-se explicar o aumento do efeito estimulatōrio do zinco quando se adiciona ferro observado sobre o crescimento do microrganismo, tanto em termos de massa micel lal como de proteina (Figuras 1 e 3).

A ação tōxica do zinco se féz notöria a partir do nivel dois tanto sobre a produção de biomassa como proteîna. Nos niveis 2 e 3, no entanto, a toxicidade fo $i$ inibida pela adição de ferro principalmente no nivel 4. Isto pode indicar uma interferéncia do zinco no metabolismo micro biano por competir com o ferro que desempenha um papel essencial na fisiolo gia celular ou por afetar a sĩntese de NAD Ou NADP atravēs da redução da atividade do sistema enzimico que sintetiza triptofano. Os átomos de nitrogēnio dos nūcleos pirrōlicos de porfirina podem formar complexos com outros metais alëm do ferro como, por exemplo, zinco e cobre (CANTAROW, 1968). E possîver que à medida que se vă aumentando a concentração de zinco ele pas se a ocupar a posição do ferro na estrutura do grupo prostético do citocromo durante sua sintese e, consequentemente, altere o mecanismo de formaçäo * de ligações de alta energia. 0 zinco pode, ainda, ser um receptor de eletrons mais forte que o ferro podendo competir com este durante a ligação de ferroproteîna não heminica oxidada com os eletrons na transferéncia dos mesmos e, desta maneira, reduzir ou, até mesmo, parailisar a sintese de ATP. Isto pode explicar o fato das produções de biomassa e proteína no maior nivel de ferro testado não terem diferido nos niveis $0,1,2$ e 3 de zinco, não sendo esta quantidade de ferro suficiente para superar o efeito competitivo do zinco no nível 4 (Tabelas 16 e 20). No entanto, esta hipótese parece não 
ser satisfatória para os resultados observados no nível 4 de zinco, pois sua combinação com o nivel zero de ferro produziu maior biomassa que com os niveis 1 e 2, mostrando que a ação dos dois microelementos na fisiologia ce lular é muito mais complexa.

O comportamento do microrganismo em relação à produção de bio massa (figuras 1 e 2) foi similar ao observado na produção de proteína (figuras 3 e 4 ), indicando que a incompatibilidade de certos niveis de ferro e zinco em relação ao crescimento também afeta a sintese de proteína.

Para o microrganismo escolhido, nas condições de cultivo refe ridas, não foi encontrada uma relação ferro:zinco definida. Assim, por exemplo, as produções tanto de biomassa como de proteîna obtidas na combina ção dos nỉveis 4 de ferro $(20,51 \mathrm{ppm})$ com 1 de zinco $(5,45 \mathrm{ppm})$ dando uma relação de 3,76 não diferiram das fornecidas pela combinação dos nỉveis 4 de ferro $(20,51 \mathrm{ppm})$ com zero de zinco $(0,45 \mathrm{ppm})$ proporcionando uma relação de 45,58 . (Tabelas 16 e 20).

Quando doses de ferro abrangendo a faixa de 15,51 a $35,51 \mathrm{ppm}$ dentro do melhor nível de zinco encontrado, ou seja, 5,45 ppm., foram testa das as produçöes tanto de biomassa como de proteina não diferiram, indicando que o nível de participação do ferro na fisiologia do fungo aumentando o efetto estimulatörio do zinco jä havia atingido o máximo e que doses do ele mento até, pelo menos, $35,51 \mathrm{ppm}$ não foram töxicas a microrganismo. Isto $\vec{e}$ de grande importāncia prätica porque oferece uma ampla faixa de segurança para o emprego do ferro na concentração de 20,51 ppm.

Variando-se os níveis de ferro no nível 4 de zinco é possível que se obtenha um aumento na produção, admitindo-se que o zinco possui efei 
to inibitörio reversível, atuando, deste modo, como um inibidor competitivo nas reações em que hã participação do ferro.

A anālise de aminoācidos determinada na biomassa produzida pela combinação dos nỉveis 4 de ferro com 1 de zinco (Tabela 21) mostrou um perfị de aminoācidos essenciais pobre em comparação com os padrões da FAO. No entanto, deve-se levar em consideração que as condições de cultivo ofere cidas ao microrganismo foram também muito pobres e que toda proteína sintetizada derivou de nitrogênio inorgänico, sendo, portanto, um rendimento pro teico líquido. A adição de outros nutrientes, tais como fosfato e magnésio, poderā melhorar estes resultados.

Quanto aos valores do pH final (Tabela 27) percebe-se que, de um modo geral, podem ser um indicador de eficiência do processo. Ao atin gir a alcalinidade o fungo não se desenvolve bem devendo-se interromper 0 crescimenţs. No entanto, a elevação do pH não parece ser a causa do mau desenvolvimento do microrganismo, mas uma consequência da deficiência do inō culo em assimilar bem a fonte de nitrogēnio permitindo que se acumule ions amōnio no meio. Desta maneira, um reajuste do $\mathrm{pH}$ para valores em torno de 3,0 não deverä restaurar o crescimento. A determinação do pH durante o processo evita, portanto, desperdĩcio de tempo com a espera de que o período de incubação se complete sem que haja uma produção adequada. 
6.4. Curva de Crescimento do Aspergilius niger IZ-9 em Meio de Amido de. Mandioca (3,0 gramas de Carboidrato por Cento), Uréia $(0,12$ gramas de Nitrogênio por Cento), Sulfato de Zinco (5,45 ppm de Zinco) e Sulfato Ferroso $(20,5] \mathrm{ppm}$ de Ferro $)$.

A curva de crescimento mostrou que o microrganismo necessita de um periodo de 36 horas para iniciar seu desenvolvimento durante o qual, talvez, ocorram as maiores alterações metabólicas, uma vez que estão sendo preparadas enzimas necessārias a adaptação do microrganismo ao novo meio. E possivel que tomando-se o inóculo de um meio de mandioca similar ao empregado e em maior quantidade este perīodo seja reduzido e uma produção māxima seja alcançada num espaço de tempo mais curto. A fase adaptativa é tanto maior quanto mais pobre ê o meio, exigindo do fungo a elaboração de muitas enzimas para sintese de substâncias, principalmente de crescimento, que podiam ser dispensadas num meio mais rico como o de malte, de onde proveio 0 inöculo. A produção de biomassa atingiu estabilidade a partir de 108 horas (Tabela 32 e Fig. 5). Em relação à produção de proteina, o fato de não ter havido diferença significativa entre os resultados obtidos a partir de 72 horas indica que a mäxima produção jä havia sido alcançada desde es.te pe rîodo ou, atê mesmo, antes disso, sendo o aumento do peso micelial decorren te do acümulo de autras substâncias que não proteỉna, como polissacarỉdeos e ripideos. 
97.

7. CONCLUSOES

Os resultados obtidos no presente trabalho permitem concluir o seguinte:

7.1. O amido de mandioca da variedade utilizada IAC-YARA não possü̈a concentrações de ferro e zinco em niveis adequados às produções mäximas de biomassa e proteina bruta por Aspergillus niger IZ-9, as quais fo ram atingidas em concentraçōes de 20,51 ppm de ferro e 5,45 ppm de zinco.

7.2. O zinco apresentou efejto töxico a partir de concentrações em torno de 10 ppm para o Aspergillus niger IZ-9.

7.3. Desconhecendo-se os teores de ferro e zinco de raizes de mandioca uti 7 izadas para o crescimento e produção de proteina por Aspergillus niger IZ-9 sugere-se que seja a icionado apenas ferro, na concentração em torno de 20 ppm, uma vez que este não $\bar{e}$ töxico em concentrações 
mais elevadas, el imina o efeito inibitörio do zinco e currige a deficiência do mesmo, se em concentrações insuficientes.

7.4. Para o Aspergillus niger 12-9, cultivado nas condições estabeleci das no presente trabalho, o melhor $\mathrm{pH}$ do meio foi encontrado estar em torno de 3 , sendo os valores de pH final acima de 8 indicadores de mau desenvolvimento do microrganismo.

7.5. Pelo perfil de aminoácidos essenciais encontrou-se que o microrganismo ë bom produtor de treonina e que o meio de cultura utilizado deve ser enriquecido com outros componentes, tais como fósforo, potássio, cālcio e magnésio, para que os aminoācidos essenciais restantes sejam produzidos em maiores proporções e/ou estudos genéticos devem ser rea lizados a fim de que se obtenham linhagens com capacidade de sintetizar tais aminoācidos em maiores quantidades. 
99.

8. SUMMARY

The objectives of the present study were:

1) to investigate whether cassava root starch contains adequate amounts of zinc and iron to provide maximum growth of a specified fungus selected to utilize this substratum as a source of carbon for protein production:

2) to determine the doses of microelements necessary for obtaining such growth, and

3) to determine whether the possible inhibiting effect of one of them, in specified concentrations, can be eliminated, or at least reduced, by the addition of the other one.

The microorganisms utilized in this trial were Aspergillus niger IZ-9. Aspergillus wentif 1 Zm-1625 and Fusarium sp. The best results were obtained with Aspergillus niger IZ-9 grown at pH 3.0. 
The results obtained when different doses of iron and zinc were added showed that starch from cassava of the variety utilized in this trial, i.e. IAC-YARA, did not contain adequate concentration levels of these elements conducive to maximum production of biomass and crude protein by Aspergillus niger 12-9. Maximum productions were attained at 20.51 ppm and 5.45 ppm concentrations of iron and zinc, respectively. It was also observed that zinc concentrations of $10 \mathrm{ppm}$ and higher have toxic effect on this microorganism. Not knowing the cassava root contents of iron and zinc utilized for growth and production of protein by Aspergillus niger IZ-9, it was suggested that only iron be added, at around $20 \mathrm{ppm}$ concentration, sin ce iron is not toxic in highen concentrations and also it eliminates the inhibiting effect of zinc and corrects its deficiency, if in insufficient concentrations. The best media pH value for Aspergillus niger IZ-9 grown under the conditions established in the present study, was found to be around 3 ; final pH values higher than 8 were indicative of poor microorganism development. Observation of the essential aminoacid profile revealed that the microorganism is a good producer of treonine and that the culture media should be erriched with other components such as phosphorus, potas sium, calcium and magnesium so that the remaining essential aminoacids are produced in higher amounts. and/or that genetic studies should be conduc ted in order to obtain strains capabie of synthetizing greater quantities of such aminoacids. 
101.

\section{LITERATURA CITA AA}

AMERICAN ASSOCIATION OF CEREAL CHEMISTS, INC., 1962. Cereal Laboratory Methods. $7^{\text {a }}$ ed. St. Paut.

BARRIOS, E. A. e R. BRESSANI, 1967. Composición Quimica de la Raĩz y de la Hoja de Algunas Variedades de Yuca Manihot. Turrialba, San José, 17 (3): $374-320$.

BLANK, L. M., 1941. Response of Phymatotrichum omnivorum to Certain Trace Elements. Journal of Agricultural Research, Washington, 62(3): 129159.

CANTAROW, A. e B. SCHEPARTZ, 1968. Biochemistry, 4․ Edição, Philadelphia, W. B. Saunders Company. 898 p.

CHVAPIL, M.s 1973. New Aspects in the Biological Role of Zinc: A Stabilizer of Macromolecules and Biological Membranes. Life Sciences, Oxford, 13: $1047-1049$.

Cochrane, V.W., 1958. Physiology of Fungi. New York, John Wiley \& Sons, Inc. $524 \mathrm{p}$. 
CocuccI, M. C. e G. ROSSI, 1972. Biochemical and Morphological Aspects of Zinc Deficiency in Rhodotorula gracilis. Archiv fur Mikrobiologie, Berlin, 85: 267-279.

COLEMAN, J. E., 1974. The Role of Zinc (II) in Transcription by $T_{7}$ RNA Polymerase. Biochemical and Biophys ical Research Communications, New York, 60(2): 641-648.

COPER, T. G. E R. SUMRADR, 1975. Urea Transport in Saccharomyces cerevisae. Journal of Bacteriology, Washington, 121: 571-576.

CURRIE, J.N., 1917. The Citric Acid Fermentation of Aspergillus niger. The Journal of Biological Chemistry, Baltimore, 31: 15-37.

FOSTER, J.W., 1939. The Heavy Metal Nutrition of Fungi. The Botanical Review, New York, 5(4): 207-239.

FOSTER, J. W. E WAKSMAN, S. A., 1939. The Specific Effect of Zinc and Other Heavy Metals on Growth and Fumaric-Acid Production by Rhizopus. Journal of Bacteriology, Baltimore, 37: 599-617.

FOSTER, J.W. e F.W. DENISON, JUN., 1950. Role of Zinc in Metabolism Nature, London, 166(4228): 833-834.

GOMES, F. P., 1973. Curso de Estatistica Experimental. 5a. ed. Piracicaba, Editora da ESALQ/USP. 430 p.

GRAY, W. D. e M. D. ABOU-EL-SEOUD, 1966. Fungal Protein for Food and Feeds. II. Manioc as a Potential Crude Raw Material for Tropical Areas. Economic Botany, New York, 20: 251-255. 
GREGORY, K.F., A. G. MEIERING, F. A. AZI , J. A. D. SEDGWICK, J. D. CUNNINGHAM, S. J. MACLEAN, J. SANTOS-NONEZ e G. GOMEZ, 1977. Estabi ishment of a Pilot Plant for the Production of Fungal Protein from Cas sava. In: Proceedings of the Fourth Symposium of the International Society for Tropical Root Crops, Ottawa, 267-270.

GUPTA, S. K. , K. K. MAGGON e T. A. VENKITASUBRAMANIAN, 1977. Effect of Zinc on Tricarboxylic Acid Cycle Intermediates and Enzymes in Relation to Aflotoxin Biosynthesis. Joúrnal of General Microbiology, New York, 99: 43-48.

HACKETTE, S. L., G. E. SKYE, C. BURTON E I. H. SEGEL, 1970. Charac terization of an Ammonium Transport System in Filamentous Fungi with Methylammonium- $C$ as the Substrate. The Journal of Biological Chemistry, Baltimore, 245(17): 4241-4250.

LILLY, V. G. e H. L. BARNETT, 1951. Physiology of the Fungi. New York, McGraw-Hilt Rook Company, Inc. $464 \mathrm{p}$.

LINEBACK, D. R。, C. E. GEORGI e R. L. DOTY, 1966. Glucoamylase ( $\alpha-1$, 4Glucan Glucohydrolase) Production by Aspergillus niger as influenced by Medium Composition. The Journal of General and Applied Microbiology, Tokyo, 12(1): 27-29.

MACMILLAN, A., 1956. The Entry of Ammonia into Fungal Cells. Journal of Experimental Botany, Oxford, I(19): 113-126.

MCHAN, F. e G. T. JOHNSON, 1970. Zinc and Amino Acids: Important Components of a Medium Promoting Growth of Monascus purpureus. Mycologia, New York, 62: 1018-1031.

MCHARGUE, J.S. E R. K. CALFEE, 1937. Effect of Manganese, Copper and Zinc on the Growth of Yeast. Plant Physiology, Baltimore, 6: 559-566. 
Mchargue, J. S. e R. K. CALfEE, 1937. Effect of Manganese, Copper, and Zine on Growth and Metabolism of Aspergillus flavus and Rhizopus nigricans. Botanical Gazzette, Chicago, 91: 183-193.

MORTON, A. G. e A. MACMILLAN, 1954. Assimilation of Nitrogen from Ammo nium Salts and Nitrate by Fungi. Journal of Experimental Botany, Oxford, $5(14): 232-252$.

MOSSERAY, R., 1932. Influence du Zinc sur les Aspergillus de la Sërie "niger" et sur Quelques Autres. Cellule, Louvain, 4i: 113-128.

NASON, A., 1950. Effect of Zinc Deficiency on the Synthes is of Tryptophan by Neurospora Extracts. Science, Washington, 112(2900): 111-112.

NASON, A. , N. O. KAPLAN e S. P. COLOWICK, 1951. Changes in Enzimatic Constitution in Zinc-Deficient Neurospora. The Journal of Biological Chemistry, Baltimore, 188(1):398-406.

PATTERSON, D. S. P., 1960. Influence of Cobalt and Zinc Ions on the Growth and Porphyrin Production of Mycobacteriuni tuberculosis avium. Nature, London, 195(4705): 57.

PECIULIS, J., E. AUGUSTAITIENE, K. PAKARSKYTE e J. VALAVIZIUS, 1969. The Role of Microelements on the Accumulation of Proteins and some Vitamins in Yeast Cells. Antonie van Leeuwenhoek, Amsterdam, 35: G 13.

PERLMAN, D. W. W. DORRELL e M. J. JOHNSON, 1946. Effect of Metallic Ions on the Production of Citric Acid by Aspergillus niger. Archives of Biochemistry, New York, 11: 137-143.

PONS, W. A. Jr., A. F. CUCULLU, L. S. LEE, J. A. ROBERTSON, A. O. FRANZ e L. A. GOLDBLATT, 1966. Determination of Aflatoxins in Agricultural Products: Use of Aqueous Acetone for Extraction. Journal of the Association of Official Analytical Chemists, Washington, 49(3): 554-562. 
PORGES, N., 1932. Citric Acid Production by Aspergillus niger. American. Journal of Botany, New York, 19: 559-567.

PRICE, C. A. E B. L. VALLEE, 1962. Euglena gracilis, a Test Organism for Study of Zinc. Plant Physiology, Washington, 37(1): 428-433.

READE, A. E. E K. F. GREGORY, 1975. High-Temperature Production of ProteinEnriched Fee from Cassava by Fungi. Applied Microbiology, Washington, 30: $897-904$.

RICHARDS, H. M., 1899. The Effect of Chemical Irritation on the Economic Coefficient of Sugar. Bulletin of the Torrey Botanical Club, New York, 26(9): $463-479$.

ROON, R. J. , H. L. EVEN, P. DUNLOP e F. L. LARIMORE, 1975. Methylamine and Ammonia Transport in Saccharomyces cerevisiae. Journal of Bacteriology, Washington, 122: 502-509.

SACHDEV, P. E D. L. DEB, 1977. Effect of Zinc on Protein and RNA content in Wheat Plant. Journal of the Science of Food and Agriculture, London, 28: $959-962$.

SANCHEZ-MARROQUIN, A. , R. CARRENTO E M. LEDEZMA, 1970. Effect of Trace Elements on Citric Acid Fermentation by Aspergillus niger. Applied Microbio. logy, Baltimore, 20(6): 888-892.

SHU, P. e M.J. JOHNSON, 1948. Citric Acid Production by Submerged Fermenta tion with Aspergillus niger. Industrial and Engineering Chemistry, Washington, 40(7): 1202-1205.

SHU, P. e M. J. JOHNSON, 1948. The Interdependence of Medium Constituents in Citric Acid roduction by Submerged Fermentation. Journal of Bacterio. logy, Baltimore, 56(5): 577-585. 
STANTON, W. R. e A. WALLBRIDGE, 1969. Fermented Food Processes. Process Biochemistry, 4: $45-51$.

STEEL, R. G. D. e J. H. TORRIE, 1960. Principles and Procedures of Statistics. New York, McGraw-Hill Book Company, Inc. $481 \mathrm{p}$.

STEINBERG, R. A., 1919. A Study of Some Factors in the Chemical Stimula tion of the Growth of Aspergillus niger. American Journal of Botany, New York, 6 ( 8 e 9 ): $330-372$.

STEINBERG, R. A., 1919. A Study of Some Factors Influencing the Stimulative Action of Zinc Sulphate on the Growth of Aspergillus niger. II.A A Comparison of Two Strains of the Fungus. Bulletin of the Torrey Botanical Club, New York, 46(1): 1-20.

STEINBERG, R. A., 1936. Some Effects of the Heavy Metals Essential for the Nutrition of Aspergillus niger upon its Growth. American Journal of Botany, New York, 23: 227-231.

STEINBERG, R. A., 1936. Relation of Accessory Growth Substances to Heavy Metals, Including Molybdenum, in the Nutrition of Aspergillus niger. Journal of Agricultural Research, Washington, 52(6): 439-448.

STEINBERG, R. A., 1937. Role of Molybdenum in the Utilization of Ammonium and Nitrate Nitrogen by Aspergillus niger. Journal of Agricultural Research, Washington, $55(12): 891-902$.

STEINBERG, R. A., 1939. Effects of Nitrogen Compounds and Trace Elements on Growth of Aspergillus niger. Journal of Agricultural Research, Washington, 59(70): 737-748.

STEINBERG, R. A., 1939, Relation of Carbon Nutrition to Trace-Element and Accessory Requirements of Aspergillus niger. Journal of Agricultural Research, Washington, 59(10): 749-763. 
TAL, M., 1969. Metal Ions and Ribosomal Conformation. Biochimica et Biophisica Acta, Amsterdam, 195: 76-86.

TOMLINSON, N. , J. J.R. CAMPBELL e P. C. TRUSSELL, 1950. The Influence of Zinc, Iron, Copper and Manganese on the Production of Citric Acid by Aspergillus niger. Journal of Bacteriology, Baltimore, 59(2): 217227.

TRUMPY, B. H. e N. F. MILLIS, 1963. Nutritional Requirements of an Asper gillus niger Mutant for Citric Acid Production. Journal of General Microbiology, New York, 30: 381-393.

VALLEE, B. L. e H. NEURATH, 1955. Carboxypeptidase, a Zinc Metalloenzyme. The Journal of Biological Chemistry. Baltimore, 217(1): 253-261.

VEGA, R. R. e D. LE TOURNEAU, 1974. The Effect of Zinc on Growth and Sclerotial Formation in Whetzelinia sclerotiorum. Mycologia, New York, 66 (2): 256-263.

WACKER, W. E. C. e B, L. VALLEE, 1959. Nucleic Acids and Metals: 1. Chromium, Manganese, Nickel, Iron and Other Metals in Ribonucleic Acid from Diverse Biological Sources. The Journal of Biological Chemistry, Balti more, $234(12): 3257-3262$.

WACKER, W. E. C., 1962. Nucleic Acids and Metals. III. Changes in Nucleic Acid, Protein, and Metal Content as a Consequence of Zinc Deficiency in Euglena gracilis. Biochemistry, Washington, $\underline{1}(5)$ : 859-865.

WATTERSON, A., 1904. The Effect of Chemical Irritation on the Respiration of Fungi. Bulletin of the Torrey Botanical Club, New York, 31: 291304.

WEGENER, W. S., J. E. SCHELL e A. H. ROMANo, 1967. Control of Malate Synthase Formation in Rhizopus nigricans. Journal of Bacteriology, Washington, $94(6): 1951-1956$. 
WEGENER, W. S. e A. H. ROMANO, 1973. Zinc Stimulation of RNA and Protein Synthesis in Rhizopus nigricans. Science, Washington, 142: 16691670.

WHITE, J.P. E G. T. JOHNSON, 1971. Zinc Effects on Growth and Cynodontin Production of Helminthosporium cynodontis, Mycologia, New York, 63(3): 548-561.

WOLD, W. S. M. e I. SUZUKI, 1976. The Citric Acid Fermentation by Aspergillus niger: Regulation by Zinc of Growth and Acidogenesis. Canadian Journal of Microbiology, Ottawa, 22(8): 1083-1092. 